INTER NATIONAL MONETARY FUND
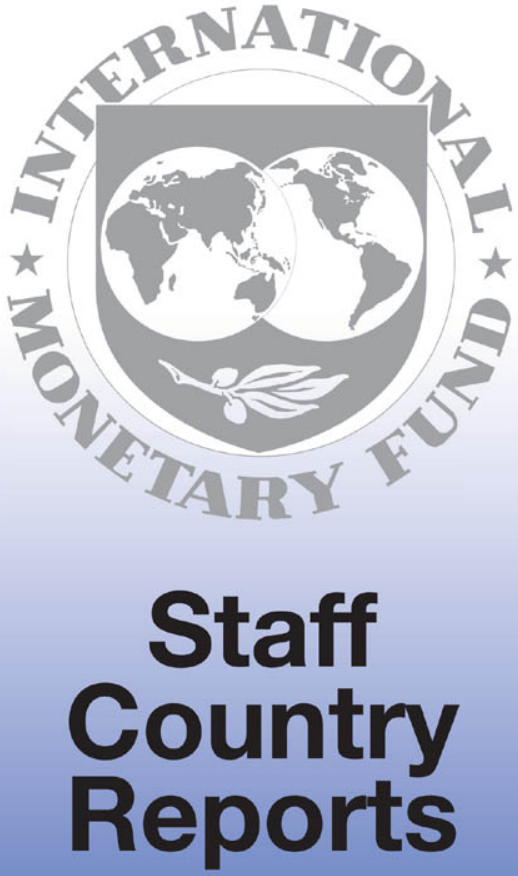
IMF Staff Country Report No. 95/136

\section{Korea-Background Papers}

This report on Korea was prepared by a staff team of the International Monetary Fund as background documentation for the periodic consultation with this member country. As such, the views expressed in this document are those of the staff team and do not necessarily reflect the views of the Government of Korea, or the Executive Board of the IMF.

Copies of this report are available to the public from

International Monetary Fund - Publication Services

700 19th Street, N.W. - Washington, D.C. 20431

Telephone: (202) 623-7430 - Telefax: (202) 623-7201

Telex (RCA): 248331 IMF UR

Internet: publications@imf.org

Price: $\$ 15.00$ a copy

International Monetary Fund

Washington, D.C. 
This page intentionally left blank 
INTERNATIONAL MONETARY FUND

KOREA

\section{Background Papers}

Prepared by a staff team consisting of E. Borensztein,

M. Schulze-Ghattas, D. Tzanninis, and H. Hirschhofer (all CTA)

Approved by the Central Asia Department

October 5, 1995

Contents

Page

I. Fiscal Policy--An Overview

1. Introduction

2. Structure of the nonfinancial public sector

a. Consolidated central government

b. Local governments

c. Nonfinancial public enterprises

3. Trends in fiscal operations

a. Expenditure

b. Tax revenue

c. Overall balance, financing, and debt

4. Assessing the stance of fiscal policy

5. Conclusions

II. Monetary Policy in Korea--Institutional Framework, Targets and Operating Procedures

1. Introduction

2. Institutional framework

a. The Bank of Korea

b. Financial institutions 19

c. Money and bond markets 2 2I

3. Intermediate targets and indicators of monetary policy 25

4. Operating procedures of monetary policy 29

a. The evolution of operating procedures 29

\begin{tabular}{ll}
\hline b. Current operating procedures & 30 \\
\hline
\end{tabular}

5. Summary 32 
III. Financial Sector Reform and External Capital Account Opening

1. Introduction

2. Financial sector reform since the early 1980s: an overview

3. Reform of the domestic financial sector

a. Policy loans, mandatory lending ratios, and credit controls

b. Deregulation of interest rates and financial instruments

c. Bank management, business boundaries, and the supervisory framework

4. Capital account opening and reform of the foreign exchange system

5. Summary

IV. Saving Behavior--Determinants and Prospects

1. Introduction 62

2. Trends in saving rates

3. Theoretical framework

a. A basic theory of aggregate saving 65

b. Further analytical issues $\quad 66$

4. Empirical specification and estimation 69

\begin{tabular}{ll} 
5. A simulation exercise & 74 \\
\hline
\end{tabular}

a. Baseline scenario 74

b. Alternative scenario I 76

c. Alternative scenario II 76

\begin{tabular}{ll} 
d. Simulation results & 77 \\
\hline
\end{tabular}

\begin{tabular}{ll} 
6. Conclusions & 77 \\
\hline
\end{tabular}

v. Output, Prices and the Balance of

Payments--A Medium-Term Scenario

VI. The Inflation Process in Korea

1. Introduction

2. Wage and price behavior in recent expansions

3. The wage-price mechanism in a small open economy

4. Wage and price determination in Korea:

some stylized facts

5. Econometric analysis of wage and price behavior 94

6. Conclusions

VII. Trade Policy

2. Bilateral issues 
I.1. Structure of the Nonfinancial Public Sector, $1995 \quad 2$

I.2. Functional Classification of Central

Government Expenditure and Net Lending, 1980-94

I.3. Tax/GDP Ratio and Composition of Tax Revenue, 1980-94

I.4. Operations of the Consolidated Central

Government, 1980-94

I.5. Consolidated Central Government--Indicators of Fiscal Policy Responses, 1985-94

I.6. Alternative Measures of the Fiscal Impulse of Various Definitions of Government, 1985-94 2

II.1. Deposit Money Banks--Structure of Assets and Liabilities 20

II.2. Selected Nonbank Financial Institutions--Structure of Assets and Liabilities

II.3. Trends in the Market Share of Financial Institutions, 1970-94

II.4. Money Market Instruments 23

II.5. Money Market Trends, 1980-94

II.6.

Monetary Targets and Outcomes, 1979-95

III.1. Domestic Financial Sector Liberalization--Schedule and Implementation of Selected Measures

III.2. Policy-Based Lending, 1980-94

III.3. Developments in Selected Deposit and

Lending Rates, 1990-95

III.4. Growth of Selected Deposits

III.5. Schedule of Planned Capital Account

Liberalization Measures

IV.1. Selected Economic Indicators, 1960-94

IV.2. Determinants of Private Saving, Estimation Results, 1970-94

IV.3. Simulation of the Private Saving Rate, 1970-2000 75

V.1. A Medium-Term Scenario, 1994-2000

VI.1. Growth, Wages, and Prices, 1985-95

VI.2. Wage Equations

VI.3. Price Equations

98

\section{Charts}

I.1. Central Government Balance, Financing, and Debt, 1980-94

II.1. Financial Institutions in Korea $20 \mathrm{a}$

II.2. Income Velocity of Money, 1980-94

II.3. M2 Growth and Target Ranges, 1988-95

$28 \mathrm{c}$

II.4. Developments in Market-Determined Interest

Rates, $1989-95$

II.5. Contributions to M2 Growth, 1989-95 
Contents

Page

IV.1. Saving, Investment, and the Current Account, 1970-94 64a

IV.2. Savings Rates, 1970-94 $64 \mathrm{~b}$

IV.3. Private Saving, Medium-Term Prospects, 1980-2000

VI.1. Demand, Output, Cost and Prices, 1985-95 $18 \mathrm{a}$

\begin{tabular}{lll}
\hline VI.2. & Price Developments, 1983-95 & 94a \\
\hline
\end{tabular}

VI.3. Wages and Productivity, 1983-95 $194 \mathrm{~b}$

VI.4. Relative Wages and Factor Income Shares, 1979-94 


\section{Fiscal Policy: An Overview 1/}

\section{Introduction}

Fiscal policy in Korea since 1982 has been guided by the medium-term objectives set out in the rolling Five-Year Plan for Fiscal Management. 2/ The size and composition of expenditure and revenue has generally been geared toward the attainment of these medium-term objectives, and short-run demand management has typically played a relatively minor role. Thus, annual budget plans have mainly reflected the priorities of the medium-term fiscal plans.

The purpose of this chapter is to provide a broad overview of the structure and characteristics of public finance in Korea, and to discuss fiscal policy in recent years against the background of the medium-term objectives. The analysis shows that despite constraints imposed by the institutional framework, the Government has managed to maintain tight budgetary control. Much of this accomplishment rests with the fact that the overriding principle of fiscal policy has been that expenditure objectives remain within the limits of revenue.

The remainder of the chapter is organized as follows. Section 2 presents a brief description of the structure of the nonfinancial public sector. Section 3 analyzes trends in the size and composition of central government expenditure, revenue, financing, and debt, against the background of the medium-term objectives of fiscal policy. Section 4 evaluates the stance of fiscal policy on the basis of summary indicators. Finally, the last section provides some concluding remarks.

\section{Structure of the nonfinancial public sector}

The nonfinancial public sector in Korea covers the consolidated central government, local governments, and nonfinancial public enterprises (Table I.I presents a simplified diagram of the organization of the Korean nonfinancial public sector).

\section{1/ Prepared by Dimitri Tzanninis.}

2/ The first of these medium-term fiscal plans went in effect in 1982 to provide general guidelines for the operation of fiscal policy in accordance with the broader development objectives and national priorities set out in the Five-Year Economic and Social Development Plans. The fiscal plans are revised annually, taking into account the macroeconomic environment and the fiscal outlook. 
Table I.1. Korea: Structure of the Nonfinancial Public Sector, 19951

Nonfinancial Public Sector

Consolidated Central Government

Central Government

$\begin{array}{lll}\text { General Special } & \begin{array}{l}\text { Special } \\ \text { Account }\end{array} & \text { Accounts } \\ & & \begin{array}{l}\text { Budgetary } \\ \text { Funds }\end{array}\end{array}$

(1)

\section{Public Enterprises}

Special Accounts

General Special Account Accounts

Public Enterprise Special Accounts

(1)
Public Enterprises

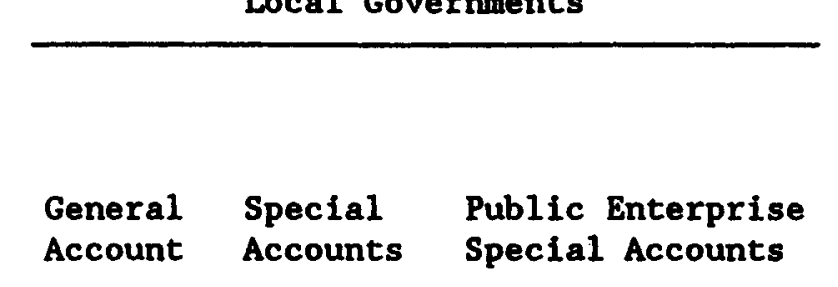

Government-invested enterprises

Government-funded enterprises

Subsidiaries of government-invested enterprises

Sources: Economic Planning Board, 1993 Budget in Brief; and Ministry of Finance and Economy, The FY 1995 Korean Budget in Brief.

1 Figures in brackets indicate the number of accounts and funds. For local governments, the number of special accounts varies by locality. 


\section{a. Consolidated central government}

The consolidated central government comprises the central government (general account, 19 special accounts, and 31 special budgetary funds) and four public enterprise special accounts. 1 / With the exception of the special budgetary funds, the general and special accounts comprise the consolidated central government budget which is submitted to the National Assembly for deliberation and approval.

The general account is the basic account of the central government and directly reflects government policies. It includes major government expenditures, such as defense, education, social and economic services, and grants to local governments, as well as most of the national tax revenue-with the exception of earmarked taxes--and some nontax revenue. The general account has usually generated surpluses, which have facilitated the transfer of funds to special accounts to offset any deficits from financing development operations. In 1994, the general account accounted for about 71 percent of total revenue and 59 percent of expenditure and net lending of the consolidated central government.

The central government special accounts have been established to finance specific projects and to manage special budgetary funds, with their revenues--usually supplemented by the general account--earmarked for specific expenditures. The most important of these accounts is the Fiscal Investment and Financing Special Account (FIFSA), which accounted for about one fifth of total expenditure and net lending of all central government special accounts in 1994. The FIFSA is mainly used for government investment in infrastructure and public enterprises, provision of policy loans by the Government, and management of the Government's external debt. It is funded primarily by dividends from, and the sale of, government-held securities, borrowing from special budgetary funds, and transfers from the general account and other special accounts. The other special accounts have been established to pursue more specific government objectives, with their revenues earmarked exclusively for these objectives. However, as dependence on earmarked revenue has contributed to a weak revenue base, the special accounts rely on transfers from the general account despite the general principle of self-financing. The operations of special accounts have usually resulted in shortfalls which have tended to offset the surplus in the general account.

The public enterprise special accounts cover the activities of a small number of nonfinancial public enterprises whose transactions are closely linked to those of the central government, thus necessitating a consolidated approach and full integration into the budget. Their purpose has been to manage certain government enterprises, and, in this capacity, they do not cover the operations of the entire public-enterprise sector.

1/ Table 15 in the Statistical Tables lists these accounts and funds. 
The special budgetary funds have been established to meet demands for various public services and achieve certain government objectives, principally the provision of financial support through net lending operations. Their number varies from year to year as government objectives change. Unlike the general account and special accounts, the special budgetary funds are outside the regular budgetary process of the consolidated central government and do not require deliberation and approval by the National Assembly. Their execution plans are formulated by the responsible ministry, approved by the President, and submitted to the National Assembly only for review. The special budgetary funds have been allowed considerable flexibility and discretion in budget execution as a result of their extra-budgetary nature. Several of them have run large deficits, affecting considerably the overall fiscal position of the consolidated central government. Recently, in an effort to improve fiscal discipline, the Government has started to integrate special budgetary funds into the formal budgetary process by abolishing problematic ones or consolidating their operations into special accounts. 1/ The special budgetary funds are not linked to the general account; instead, they transfer funds to or borrow from the FIFSA and other special accounts.

\section{b. Local governments}

There are approximately 300 local governments in Korea. Local governments have the power to formulate their own budgets which are approved by the respective local councils without requiring approval by the central government. 2/ However, the central government can exercise a degree of influence through limiting borrowing, providing grants from the general account to allocate revenue from sharing taxes, and underwriting localgovernment bonds. By law, a fixed portion of central government tax revenue is allocated to local governments in the form of grants. These grants have been used by the central government to correct fiscal imbalances and promote equality between the central and local governments and among local governments. In addition to these grants, local governments finance their operations with local tax and nontax revenue and local-government bonds.

\section{c. Nonfinancial public enterprises}

Nonfinancial public enterprises are productive entities in which the Government maintains ownership (i.e., it holds at least 10 percent of the outstanding equity) either directly or indirectly through other public entities. The extent of government ownership distinguishes them to government-invested enterprises (the Government holds at least 50 percent of

1) One such fund, the Grain Management Fund, was abolished in 1994 due to excessive accumulation of debt in grain-support operations. Its operations were taken over by the Grain Management Special Account.

2) In general, local-government budgets include a general account, a number of special accounts (including an education special account), and local public enterprise special accounts. 
the outstanding equity), and government-funded enterprises (the Government holds less than 50 percent of the outstanding equity). Subsidiary companies of government-invested enterprises are also classified as public enterprises.

Nonfinancial public enterprises operate on a commercial basis outside the consolidated central government budget, principally in the public utilities, manufacturing, and transport, storage and communications sectors. Their operations are financially independent from the budget, which includes only transfers to and from the public enterprises, notably through the public enterprise special accounts. Public enterprises are allowed to borrow from foreign sources, albeit subject to ceilings; however, they enjoy no special privileges on domestic borrowing.

\section{Trends in fiscal operations}

Fiscal policy has traditionally been an important vehicle for the Government's medium-term objectives. 1/ During the early 1980s, stabilization took precedence, and the deficit of the consolidated central government budget was brought down from an average of 3.9 percent of GDP during 1980-82 to 0.9 percent of GDP during 1983-86. Following the overall success of the stabilization efforts and the improvement in the fiscal and external balances, the priorities of fiscal policy in the late 1980s shifted toward the provision of social services, income redistribution through tax reform, and the extension of the social security system. This reorientation came in response to public concern regarding improvements in social welfare and the distribution of the benefits of economic growth. In recent years, fiscal policy has focused on addressing pressing infrastructure needs, enhancing the country's international competitiveness by investing in education and new technologies, and promoting social welfare.

\section{a. Expenditure}

Despite the important role the central government budget has played in support of government objectives, the size of the government (as expressed by the ratios of expenditure and tax revenue to GDP) has remained relatively moderate in relation to the size of the economy (Tables I.2 and I.3). 2/ The ratio of central government expenditure to GDP has remained at or below 20 percent, considerably lower than many other countries. The expenditure

1/ The principal objectives of the previous two Five-Year Economic and Social Development Plans were: economic stability, efficiency, and balanced regional and sectoral development (1982-86); and, social welfare, efficiency, and equity in the distribution of income and wealth (1987-1991). The current Five-Year Plan for the New Economy (1993-1997) has set the objectives of enhancing the growth potential of the economy, promoting internationalization, and improving the standards of living.

2/ The fiscal year coincides with the calendar year for all levels of government. 
Table I.2. Korea: Functional Classification of Central Government Expenditure and Net Lending, $1980-94$

1980

1982

1984

1986

1994

\section{(In percent of total expenditure)}

General public services

Defense

Education

Social services $1 /$

Economic services

Grants and others 2/

Total expenditure and net lending 100.
General public services

Defense

Education

Social services $1 /$

Economic services

Grants and others 2/

Total expenditure and net lending

Memorandum item:

General government

expenditure and net lending

\begin{tabular}{rr}
8.5 & 9 \\
30.6 & 27 \\
14.6 & 17 \\
9.9 & 13 \\
26.0 & 21 \\
10.4 & 11 \\
\hline
\end{tabular}

100.

9.0

26.6

16.8

15.0

19.1

$\underline{13.6}$

100.0

\begin{tabular}{rr}
10.0 & 9.0 \\
27.5 & 25.2 \\
17.0 & 17.7 \\
12.5 & 14.1 \\
18.1 & 19.4 \\
14.9 & 14.5 \\
\hline
\end{tabular}

100.0

100.0
8.5

20.0

17.0

20.4

20.4

13.7

100.0

9.8

19.3

14.4

17.9

18.7

19.8

$100.0 \quad 100.0$

\section{(In percent of GDP)}

$\begin{array}{llllllll}1.7 & 2.0 & 1.6 & 1.7 & 1.4 & 1.6 & 1.8 & 1.9 \\ 6.2 & 5.8 & 4.9 & 4.6 & 4.0 & 3.7 & 3.6 & 3.3 \\ 2.9 & 3.6 & 3.1 & 2.8 & 2.8 & 3.1 & 2.7 & 3.6 \\ 2.0 & 2.9 & 2.7 & 2.1 & 2.2 & 3.8 & 3.4 & 3.6 \\ 5.2 & 4.6 & 3.5 & 3.0 & 3.0 & 3.8 & 3.5 & 4.4 \\ \underline{2.1} & \underline{2.4} & \underline{2.5} & \underline{2.5} & \underline{2.3} & \underline{2.5} & \underline{3.7} & \underline{2.9}\end{array}$

20.1

21.3

18.3

16.6

15.7

18.5

18.7

19.7

24.3

25.3

22.3

20.6

19.5

23.5

25.1

26.3

Sources: Bank of Korea, Economic Statistics Yearbook; and data provided by the Korean authorities .

1/ Includes health, social security and welfare, housing and community amenities, and other community and social services.

2/ Includes transfers to local govermments and interest. 
Table I.3. Korea: Tax/GDP Ratio and Composition of Tax Revenue, 1980-94

\begin{tabular}{|c|c|c|c|c|c|c|c|c|}
\hline & 1980 & 1982 & 1984 & 1986 & 1988 & 1990 & 1992 & 1994 \\
\hline \multicolumn{9}{|c|}{ (In percent of GDP) } \\
\hline \multicolumn{9}{|l|}{ Tax/GDP ratio } \\
\hline $\begin{array}{l}\text { Total tax revenue } 1 / \\
\text { of which: }\end{array}$ & 16.7 & 17.5 & 17.1 & 16.5 & 17.7 & 18.5 & 18.6 & 19.8 \\
\hline National tax revenue & 14.6 & 15.4 & 15.0 & 14.6 & 15.2 & 14.9 & 14.6 & 15.5 \\
\hline \multicolumn{9}{|c|}{ (In percent of total) } \\
\hline \multicolumn{9}{|l|}{$\begin{array}{l}\text { Composition of tax } \\
\text { Total tax revenue } 1 /\end{array}$} \\
\hline Direct & 36.9 & 37.5 & 38.1 & 38.9 & 44.9 & 49.5 & 52.6 & $\ldots$ \\
\hline Indirect & 63.1 & 62.5 & 61.9 & 61.1 & 55.1 & 50.5 & 47.4 & $\ldots$ \\
\hline National tax revenue & & & & & & & & \\
\hline Direct & 28.7 & 31.2 & 28.9 & 31.6 & 37.9 & 43.7 & 45.3 & 45.7 \\
\hline Indirect & 71.3 & 68.8 & 71.1 & 68.4 & 62.1 & 56.3 & 54.7 & 54.3 \\
\hline
\end{tabular}

Sources: Economic Planning Board. The FY 1994 Korean Budget; data provided by the Korean authorities; and staff estimates and calculations.

1) Includes all national and local taxes. 
ratio declined substantially during the 1980s, as the Government's principal objective shifted from promoting growth during the 1970 s to stabilizing the economy and promoting efficiency with the assistance of fiscal consolidation. It increased again in the 1990s, reflecting government efforts to raise spending on infrastructure investment and other target areas, financed by an increase in the tax ratio.

While the overall expenditure ratio has remained relatively moderate, the structure of expenditure has changed substantially since the early $1980 \mathrm{~s}$, mirroring shifts in national priorities. The share of defence spending in total outlays was reduced drastically, reflecting a successful rationalization effort and the gradual improvement in the external security environment. The reduction in the share of defence in the budget released substantial resources for other priority areas.

Expenditure in education has been maintained at around 3 percent of GDP since the early 1980s, supported by an education surtax that was introduced in 1982. The temporary decline in the expenditure share of education in 1992 reflected the transfer in the previous year of the education surtax to an education special account for local governments. However, the share of education increased subsequently, as education was accorded greater priority in the current five-year plan.

The shift in government priorities in the late 1980 s was mainly reflected in increased spending on social services. The share of social services in the budget almost doubled during the last 15 years, mainly on account of increased spending on housing and community development projects, and financial support for social security programs. In the late 1980s, in particular, a sizable reduction in the share of defence spending facilitated a substantial increase in the share of social services in the budget.

The share of economic services in central government expenditure declined considerably during the first half of the $1980 \mathrm{~s}$. The decline reflected partly the higher priority given to social services, and also the change in government policies from direct support of industries to indirect support, focusing on measures to promote efficiency and competition. Nonetheless, the share rose again in the late 1980 s when, in response to mounting infrastructure bottlenecks and calls for agricultural support, the Government increased spending on infrastructure investment and the restructuring of the agricultural sector.

Finally, grants to local governments have remained broadly stable in relation to GDP since the early 1980s, owing mainly to the fact that grants are a constant share of central government tax revenue, which grew roughly in proportion to GDP. A temporary increase in the early 1990s reflected the transfer of the education surtax in 1991 to an education special account for local governments. 


\section{b. Tax revenue}

One of the principal objectives of tax policy since 1982 has been to reduce the regressiveness of the tax system by increasing the reliance on direct taxes through strengthening taxes on property and land. There were no major tax reforms in the $1980 \mathrm{~s}$, but a number of tax measures and tax incentives--the latter primarily aimed at housing construction--were introduced. The most important changes were the abolition of most tax privileges to heavy and export industries in 1981, the introduction of the education surtax in 1982, and the limited tax reform of 1988 . The latter came in response to intense public calls regarding the distribution of income and wealth. Among the principal aims of the 1988 tax reform was the reduction in the tax burden of low- and middle-income individuals. This was accomplished by lowering the marginal tax rates of the personal income tax and the inheritance tax, increasing the personal exemption level of the income tax, and removing certain consumer durables from the list of items subject to the special excise tax. These measures slowed considerably the growth of tax revenue as evidenced by the temporary decline in the national tax ratio after 1988 (Table I.3).

Tax reforms in the 1990 s were more comprehensive. In 1990, marginal tax rates of the personal income tax were reduced and a new tax on excess land profits was introduced to combat land speculation. As a part of the Five-Year Plan for the New Economy (1993-97), a multi-year tax reform plan was announced in 1993. If The reform plan intended to: increase the fairness of the tax system by subjecting all financi.ll income to taxation; improve its efficiency by expanding the revenue base and reducing marginal tax rates, exemptions and deductions; and, mobilize resources for expenditure in priority areas--such as infrastructure investment, education, social welfare, and the environment--by raising the tax ratio to about 22.5 percent of GDP by 1997.

Against the backdrop of these reforms, the national tax ratio remained broadly stable in the early 1990s, increasing only recently, partly on account of the implementation of measures in the multi-year tax reform plan. Notwithstanding a sizable increase in locally raised tax revenue in recent years, the local tax ratio remains relatively low. Measures aimed at reducing the regressiveness of the tax system by increasing direct taxation have resulted in a steady increase in the share of direct taxes in national tax revenue. Nevertheless, the Korean tax system continues to rely heavily on indirect taxes mainly for their administrative convenience.

\section{c. Overall balance, financing, and debt}

Despite the variety of objectives pursued by the central government and the operation of special accounts and funds which potentially complicate

1) Details of the plan are discussed in "Korea - Recent Economic Developments" (SM/94/28, 1/31/94), Chapter III. 
fiscal management, the government has maintained tight budgetary control. This achievement is owed to a broad consensus on fiscal conservatism, and has limited fiscal deficits, financing requirements, and government debt.

In support of the stabilization efforts in the early 1980s, the authorities were successful in controlling the budget deficit and central government debt (Table I.4 and Chart I.1). The budget deficit was brought under control within a few years and the commitment to fiscal discipline has since been maintained. For the first time since 1979, when the government consolidated its fiscal accounts into a unified budget, the balance of the consolidated central government registered a surplus in 1987 of about 0.2 percent of GDP. Since then, the consolidated central government budget has been, on average, roughly balanced.

In the first half of the 1980s, about one third of the budget deficit was financed from foreign sources, aggravating Korea's external debt problem. Following fiscal consolidation and the improvement in the balance of payments, foreign financing of the consolidated central government balance started registering net repayments in 1986, in line with the Government's efforts to pay back its external debt. Against this background, central government debt fell from a peak of about 17 percent of GDP in 1982 to around eight percent in the 1990s.

\section{Assessing the stance of fiscal policy}

The preceding section has argued that fiscal policy in Korea has been used primarily for the achievement of the Government's medium-term objectives. However, while short-term cyclical considerations have played a subordinate role in fiscal management, changes in the budget balance nevertheless affect aggregate demand, thus necessitating a closer examination of this influence.

Changes in the budget balance tend to be poor indicators of the cyclical impact of fiscal policy, because certain revenue and expenditure categories are affected by cyclical conditions and it is therefore not always clear whether such changes are the cause or the result of economic fluctuations. In order to overcome this shortcoming, special indicators of the cyclical impact of fiscal policy have been developed. $1 /$ One such indicator, the fiscal impulse measure, has been widely applied by Fund staff and is used in this section to examine the role of fiscal policy in recent business cycles in Korea. Fiscal impulse measures for different definitions of the central govermment balance and for different levels of government (central and general) are discussed. In addition, another fiscal indicator, the change in the structural balance, is briefly reviewed.

1/ For a detailed discussion of such fiscal indicators see Heller et al. (1986). 
Iable I.4. Korea: Operatione of the Coneolldated Contral Government, 1980-94

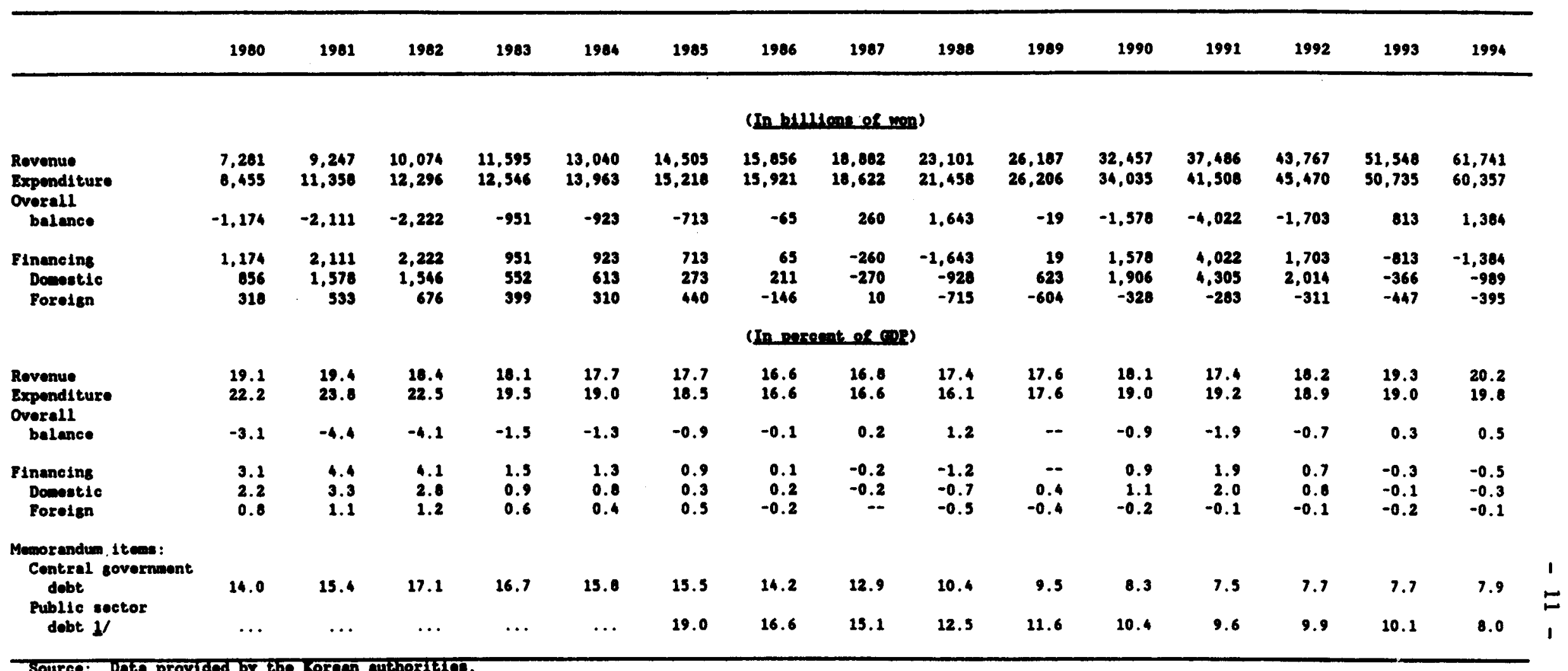

1) The public sector covers the contrel sovernent and nonfinencial public enterprises. 
The basic idea underlying the fiscal impulse measure is that in order to assess the impact of changes in the budget balance on aggregate demand, it is necessary to adjust the balance for the effects of economic fluctuations on revenue and expenditure. The fiscal impulse measure does this by comparing the actual budget with a "cyclically-neutral budget". 1/ The fiscal impulse concept has been criticized because it focusses on the overall cyclical impact of fiscal policy and fails to distinguish between discretionary policy measures and the effects of automatic stabilizers. The indicator based on the change in the structural balance attempts to overcome this shortcoming by adjusting for the effects of automatic stabilizers. It is thus a measure of the effects of discretionary fiscal policy rather than the overall cyclical impact of the budget. $2 /$

Calculations of fiscal indicators for the consolidated central government are summarized in Table I.5. The fiscal impulse calculations suggest that despite the relatively small size of the fiscal balance in relation to GDP, changes in the fiscal position have, on several occasions, had a substantial impact on changes in aggregate demand, and have at times, notably during $1990-93$, been procyclical. $3 /$

While fiscal policy was, on average, moderately restrictive during the expansion of 1986-88, it turned expansionary in 1989 in an effort to offset partly a sharp decline in net foreign demand. Fiscal policy remained expansionary in the 1990-91 expansion, imparting a substantial procyclical impact on aggregate demand. After a roughly balanced budget in 1989 , the fiscal position moved into deficit in 1990, which widened further in the following year to nearly 2 percent of GDP. The deterioration in the fiscal position was mainly due to expenditure increases in priority areas, and tax measures designed to increase equality which lowered revenue growth. The combined effect of these measures implied a positive fiscal impulse of over 1 percent of GDP per year in 1990-91, which contributed to the rapid growth in aggregate demand and the overheating of the economy.

In 1992, tighter monetary policy and restrictions on construction activity to rein in aggregate demand led to a cyclical downturn. Fiscal policy reinforced the cyclical downturn. Despite strong revenue growth, expenditure was kept subdued in 1992 and the deficit narrowed, with an

1) The difference between the actual budget and the cyclically-neutral budget is defined as the fiscal stance. The fiscal impulse refers to changes in the fiscal stance and thus measures the impact of fiscal policy on changes in aggregate demand. For a more detailed description of the calculation of the fiscal impulse see footnotes to Table I.5, as well as Heller et al. (1986).

2/ See footnotes to Table I.5 for details on the calculation of the structural balance.

3/ Positive fiscal impulse statistics imply expansionary stance of fiscal policy. 
CHART 1.1

KOREA

CENTRAL GOVERNMENT BALANCE, FINANCING, AND DEBT, 1980-94

(In percent of GDP)
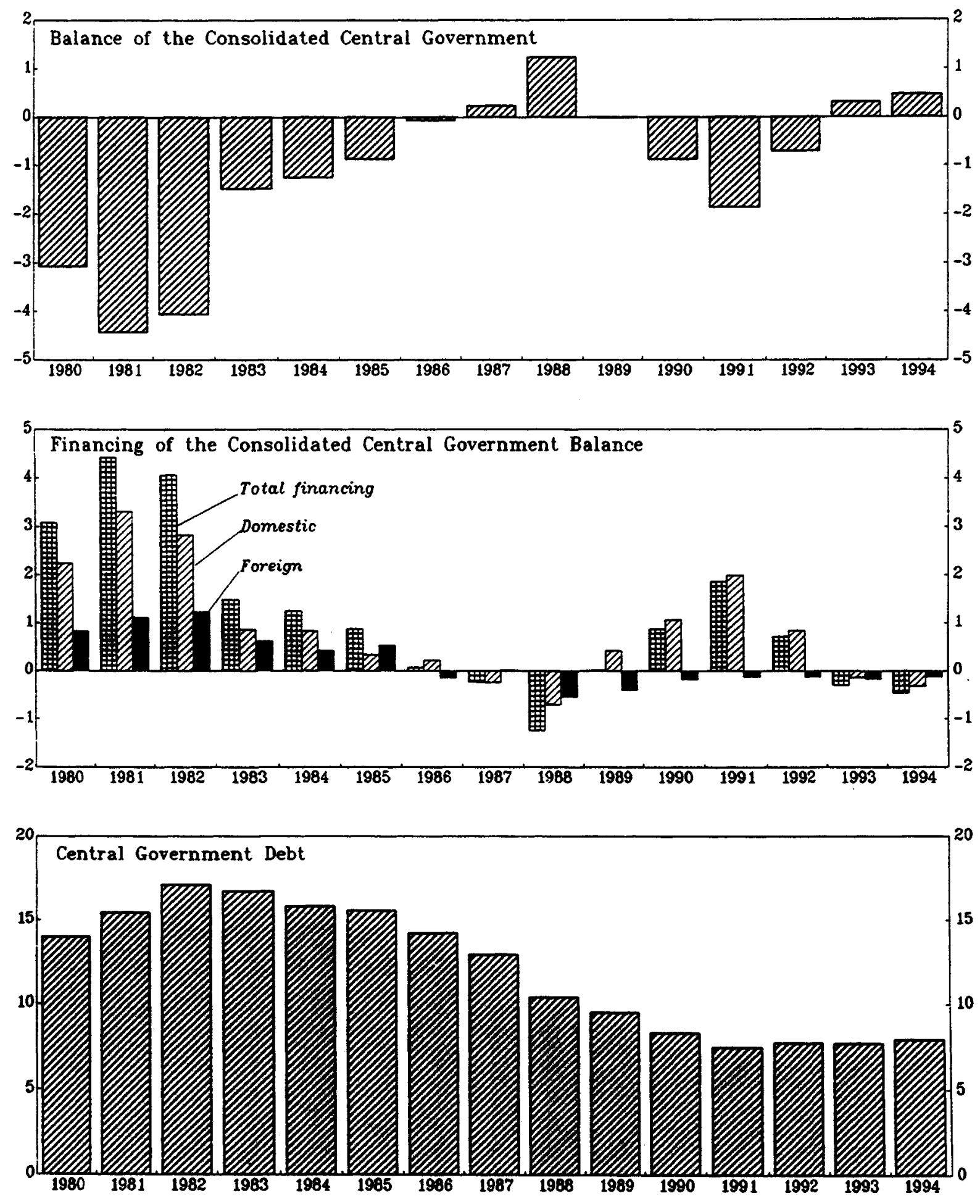

Sources: Data provided by the Korean authorities; and staff calculations. 
Table I.5. Korea: Consolidated Central Government--Indicators of Fiscal Policy Responses, 1985-94 (In percent of GDP)

\begin{tabular}{|c|c|c|c|c|c|c|c|c|c|c|}
\hline & 1985 & 1986 & 1987 & 1988 & 1989 & 1990 & 1991 & 1992 & 1993 & 1994 \\
\hline Overall balance & -0.87 & -0.07 & 0.23 & 1.23 & -0.01 & -0.88 & -1.86 & -0.71 & 0.30 & 0.45 \\
\hline Fiscal stance $1 /$ & 0.41 & -- & 0.04 & -0.66 & 0.18 & 1.20 & 2.32 & 0.75 & -0.58 & -0.61 \\
\hline Fiscal impulse $2 /$ & -0.58 & -0.41 & 0.04 & -0.70 & 0.84 & 1.02 & 1.12 & -1.57 & -1.33 & -0.03 \\
\hline Structural balance $\underline{3} /$ & -0.47 & -0.07 & -0.11 & 0.62 & -0.25 & -1.29 & -2.46 & -0.82 & 0.51 & 0.54 \\
\hline Structural impulse 4 / & -0.46 & -0.34 & 0.05 & -0.71 & 0.79 & 1.08 & 1.38 & -1.33 & -1.23 & -0.09 \\
\hline $\begin{array}{l}\text { Memorandum item: } \\
\text { Real GDP (annual percent change) }\end{array}$ & 6.93 & 11.55 & 11.52 & 11.27 & 6.38 & 9.51 & 9.13 & 5.07 & 5.75 & 8.37 \\
\hline
\end{tabular}

Sources: Data provided by the Korean authorities; and staff estimates and calculations.

1/ Defined as the difference between a "cyclically-neutral budget" and the actual budget. The former is defined as the budget in which expenditures grow at the rate of growth of potential output in nominal terms, and revenues grow at the rate of growth of actual nominal output.

2/ Defined as the change in the fiscal stance.

3/ Defined as the difference between a "full-employment budget" and the fiscal stance. The former is defined as the budget in which expenditures and revenues grow at the rate of growth of potential output in nominal terms. 4f Defined as the (negative) change in the structural balance. 
attendant withdrawal of stimulus of over 1.5 percent of GDP. Fiscal policy remained restrictive in 1993, despite the initially moderate pace of the recovery. Cuts in planned expenditure in anticipation of shortfalls in revenue--which did not materialize--resulted in an unexpected budget surplus, which implied again a substantial withdrawal of stimulus. Most recently, however, the Government has paid somewhat more attention to the cyclical impact of fiscal policy. In 1994, in line with cyclical requirements, fiscal policy avoided adding to resource pressures and was broadly neutral, with the surplus of the consolidated central government increasing slightly to about 0.5 percent of GDP.

The results in Table I.5 suggest that alternative measures of the cyclical impact of fiscal policy during 1985-94--i.e., the fiscal impulse and changes in the structural balance--convey essentially the same picture. A question that needs to be addressed, however, is whether the definition of the fiscal balance that was used for the calculations--the balance of the consolidated central government on a cash basis--is the appropriate measure of fiscal operations. In particular, two issues need to be clarified: the choice of an accounting system, and the coverage of government.

The first issue concerns the choice between a cash-based and a national accounts-based accounting system. While a cash-based accounting system is more closely linked to financing flows--and thus seems preferable when the analysis focuses on the financial implications of fiscal operations--a national accounts-based concept is more closely related to developments in aggregate demand. In particular, in a cash-based accounting system, net lending and asset sales by the Government are included in expenditure and revenue, respectively, thus affecting the overall fiscal position and the measured stance of fiscal policy, even though they do not directly affect aggregate demand. In the case of net lending, the Government mainly acts as a financial intermediary, while an asset sale is in essence a change in the liquidity structure of government assets. National accounts data correct for this shortcoming by focusing on real, rather than financial transactions. A national accounts-based measure of the budget balance may thus be more appropriate for an analysis of the effect of the budget on real economic activity.

The second issue concerns the scope of government operations. Since the operations of local govermments are significant in size and, to a considerable degree, influenced by the central government, a broader coverage of government might be more appropriate for capturing the true impact of government operations on the economy.

Table I.6 compares fiscal impulse indicators for different definitions of the government balance (using cash- and national accounts-based data) and for different levels of government. For most years, the indicators calculated from cash- and national accounts-based data for the central government are fairly similar, but in some cases they differ significantly. In 1985, 1986, and 1990, for example, the two measures point in opposite directions. The fiscal impulse measure calculated for the cash-based 
Table I.6. Korea: Alternative Measures of the Fiscal Impulse of Various Definitions of Government, 1985-94

(In percent of GDP)

\begin{tabular}{|c|c|c|c|c|c|c|c|c|c|c|}
\hline & 1985 & 1986 & 1987 & 1988 & 1989 & 1990 & 1991 & 1992 & 1993 & 1994 \\
\hline $\begin{array}{l}\text { Central government } 1 / \\
\text { Cash basis } \\
\text { Cash basis (excluding net lending) } \\
\text { National accounts basis }\end{array}$ & $\begin{array}{r}-0.18 \\
0.10 \\
0.21\end{array}$ & $\begin{array}{r}-0.67 \\
0.22 \\
0.21\end{array}$ & $\begin{array}{l}-0.18 \\
-0.32 \\
-0.35\end{array}$ & $\begin{array}{l}-0.78 \\
-0.70 \\
-1.01\end{array}$ & $\begin{array}{l}0.91 \\
0.77 \\
0.20\end{array}$ & $\begin{array}{r}1.01 \\
-0.21 \\
-0.42\end{array}$ & $\begin{array}{l}1.08 \\
1.23 \\
0.88\end{array}$ & $\begin{array}{l}-1.54 \\
-0.97 \\
-0.23\end{array}$ & $\begin{array}{l}-1.45 \\
-1.28 \\
-1.42\end{array}$ & $\begin{array}{r}0.43 \\
-0.12 \\
\ldots\end{array}$ \\
\hline $\begin{array}{l}\text { Consolidated central government } 2 / \\
\text { Cash basis } \\
\text { Cash basis (excluding net lending) } \\
\text { National accounts basis }\end{array}$ & $\begin{array}{r}-0.58 \\
-0.30 \\
\ldots\end{array}$ & $\begin{array}{r}-0.41 \\
0.48 \\
\cdots\end{array}$ & $\begin{array}{r}0.04 \\
-0.11 \\
\ldots\end{array}$ & $\begin{array}{r}-0.70 \\
-0.62 \\
\cdots\end{array}$ & $\begin{array}{l}0.84 \\
0.70 \\
\ldots\end{array}$ & $\begin{array}{r}1.02 \\
-0.21 \\
\ldots\end{array}$ & $\begin{array}{r}1.12 \\
1.27 \\
\ldots\end{array}$ & $\begin{array}{r}-1.57 \\
-1.00 \\
\cdots\end{array}$ & $\begin{array}{r}-1.33 \\
-1.16 \\
\ldots\end{array}$ & $\begin{array}{r}-0.03 \\
-0.59 \\
\ldots\end{array}$ \\
\hline $\begin{array}{l}\text { General government } \underline{3} / \\
\text { Cash basis } \\
\text { Cash basis (excluding net lending) } \\
\text { National accounts basis }\end{array}$ & $\begin{array}{l}0.08 \\
0.18 \\
0.13\end{array}$ & $\begin{array}{l}-0.89 \\
-0.06 \\
-0.06\end{array}$ & $\begin{array}{l}-0.63 \\
-0.70 \\
-0.73\end{array}$ & $\begin{array}{l}-0.64 \\
-0.61 \\
-0.75\end{array}$ & $\begin{array}{r}0.31 \\
-0.08 \\
-0.50\end{array}$ & $\begin{array}{r}0.89 \\
-0.07 \\
-0.27\end{array}$ & $\begin{array}{l}1.57 \\
1.73 \\
1.55\end{array}$ & $\begin{array}{r}-1.15 \\
-0.68 \\
0.12\end{array}$ & $\begin{array}{l}-2.36 \\
-1.95 \\
-1.62\end{array}$ & $\begin{array}{l}\cdots \\
\cdots \\
\cdots\end{array}$ \\
\hline
\end{tabular}

Sources: Bank of Korea, National Accounts and Economic Statistics Yearbook; data provided by the Korean authorities; and staff estimates and calculations.

1/ Includes: on a cash basis, the central government (general account, the special accounts and the special budgetary funds); on a national accounts basis, the central government and the social security funds (after netting out the relevant intragovernmental transfers).

2/ Includes the central government and the public enterprise special accounts.

3/ Includes: on a cash basis, the central government and the local governments (excluding public enterprise special accounts of the central and local governments); on a national accounts basis, the central government, the local governments and the social security funds. 
balance of the central government excluding net lending operations suggests that the latter account for a large part, albeit not all, of the difference between the two measures. Other factors, notably differences in the timing of reporting transactions (cash versus accrual method) and the treatment of asset sales, appear to have played a role as well.

A comparison of the fiscal impulse measures for the central and general goverment, both on cash and national accounts basis, suggests that the fiscal operations of local governments generally have a relatively small effect on aggregate demand. Nevertheless, while both measures generally point in the same direction, in some years, the magnitude of the cyclical impact is quite different.

To summarize, alternative fiscal impulse measures calculated for different definitions of the fiscal balance and for different levels of government do not fundamentally change the assessment of the cyclical impact of fiscal policy outlined above.

\section{Conclusion}

This chapter has examined the structure of Korea's public finances and the conduct of fiscal policy since the early 1980s. The analysis revealed a number of salient features. First, despite some constraints imposed by the structure of public finances, the Korean Government has generally managed to maintain tight budgetary control. Second, the size of the government has remained relatively small in relation to GDP, even though a wide range of objectives have been assigned to fiscal policy. The objectives have generally been met by shifting the composition of expenditure, rather than increasing the overall size. Finally, fiscal policy has primarily been used to serve the Goverment's medium-term fiscal objectives, and has, until recently, paid limited attention to the cyclical impact of the budget on the economy. As a result, fiscal policy has sometimes amplified cyclical movements in private demand. This has been confirmed by a range of indicators of the stance of fiscal policy. However, since 1994, fiscal policy appears to have paid somewhat more attention to the cyclical impact of the budget, striking a balance between meeting cyclical requirements and medium-term objectives. 


\section{References}

Economic Planning Board (1993), 1993 Budget in Brief, Republic of Korea. (1994), The FY 1994 Korean Budget, Republic of Korea.

Heller, P. S., R. D. Haas, and A. S. Mansur (1986), "A Review of the Fiscal Impulse Measure," International Monetary Fund, Occasional Paper No. 44.

International Monetary Fund, "Korea - Recent Economic Developments," $\mathrm{SK} / 94 / 28,1 / 31 / 94$.

Ministry of Finance and Economy (1995), The FY 1995 Korean Budget in Brief, Republic of Korea.

Park, Chong-Kee (1992), "The Korean Public Finance: An Overview," in K. Choi, D. K. Kim, T. Kwack, and K. Y. Yun (eds.), Public Finance in Korea, Seoul National University Press.

Yoon, Young-Dae (1992), "The Control and Management of Government Expenditure: The Case of Korea," Korea Development Institute, Working Paper No. 9219. 
II. Monetary Policy in Korea--Institutional Framework, Targets and Operating Procedures $1 /$

\section{Introduction}

Monetary policy in Korea has traditionally operated within a framework designed to foster investment and growth through preferential financing for targeted sectors and activities. In the $1970 \mathrm{~s}$, government intervention in the allocation of credit was extensive and monetary policy relied heavily on direct control instruments. The objective of promoting investment took precedence over price stabilization, with annual inflation rates averaging 16.9 percent. After 1979 , policy priorities shifted toward stabilization, while government intervention in the financial system was gradually scaled back. This reorientation of policies succeeded in bringing inflation down to 5.6 percent during 1985-94. At present, the medium-term goal of monetary policy is to lower inflation further to partner country levels. At the same time the Government's financial sector reform program envisages the phasing out of the remaining nonmarket elements in the operating procedures of monetary policy and the move to a fully market-based system. 2 /

This chapter reviews the institutional framework, targets and indicators, as well as operating procedures of monetary policy in Korea. Section 2 describes the main features of financial institutions and markets. Section 3 discusses the intermediate targets and indicators that have been used to conduct monetary policy. Section 4 describes how monetary policy has operated--the main instruments and how they have been employed. Finally, section 5 contains a brief summary.

\section{Institutional framework}

The Korean financial system consists of the Bank of Korea (BOK), banks and nonbank financial institutions, as well as money and securities markets. Financial institutions and markets have traditionally been subject to extensive government regulation and intervention and have undergone significant structural changes since the early 1980 s as a result of partial liberalization. One of the most notable developments has been the strong expansion of nonbank financial institutions and the simultaneous decline in the market share of deposit money banks. At the same time, the importance of the money market has gradually increased, as a less restrictive regulatory environment allowed the introduction of new instruments and thus improved the market's intermediation capacity.

1 Prepared by Harald Hirschhofer with assistance from Eduardo Borensztein and Marianne Schulze-Ghattas.

2/ The financial sector reform program is discussed in chapter III. 


\section{a. The Bank of Korea}

Established in 1950 under the Bank of Korea Act, the BOK has been assigned the task of maintaining the stability of the value of money and furthering the efficient utilization of national resources through the sound operation and functional improvement of the banking and credit system. $1 /$ The BOK is responsible for the implementation of monetary policy, issues bank notes and coins, and acts as lender of last resort of the banking system as well as the Government's bank. In the latter capacity it may extend credit to the Government in the form of advances or purchases of government bonds. The BOK is also responsible for the supervision of banking institutions and for holding and managing foreign exchange reserves.

The BOK acts under the direction and supervision of the Monetary Board, which consists of the Minister of Finance and Economy and the Governor of the BOK, who are members ex officio, as well as representatives of other ministries and banking institutions. 2/ The Monetary Board formulates monetary policy and guides the BOK's supervisory activities.

\section{b. Financial institutions}

The financial sector in Korea consists of two distinct groups of institutions whose roles and regulatory treatment have differed substantially: deposit money banks (DMBs) and nonbank financial institutions (NBFIs) (Chart II.1). In 1994, the group of DMBs comprised 96 commercial banks (14 nationwide banks, 10 local banks, 72 foreign bank branches) and 6 specialized banks. Commercial banks engage in short- and long-term financing, the foreign exchange business, and other financial services--while the partly government-owned, specialized banks provide preferential loans for special sectors such as housing, agriculture, and small - and medium-size enterprises (SMEs). Both commercial banks (with the exception of foreign bank branches) and specialized banks have traditionally played a key role as outlets for the Government's policy-based lending and have thus been subject to a greater degree of government regulation than other financial institutions.

The main funding source of DABs is deposits (including CDs), which accounted for over half of their total liabilities and net worth in 1994 . Within the DMB sector, foreign bank branches have only a small deposit base and rely mainly on foreign (interoffice) liabilities for funding (Table II.1). Borrowing from the BOK and the Government accounted for 4 percent and 3 percent, respectively, of DMB' total liabilities and net worth in 1994, with borrowing from the Government concentrated mainly among

1/ Bank of Korea (1993).

2) The Governor of the BOK is appointed by the President upon recommendation by the Minister of Finance and Economy. The central bank act is currently under revision and a change in the composition of the Monetary Board is being considered. 
Table II.1. Korea: Deposit Money Banks--Structure of Assets and Liabilities (In percent of total assets, end of 1994)

\begin{tabular}{|c|c|c|c|c|}
\hline & $\begin{array}{c}\text { Nationwide } \\
\text { Commercial } \\
\text { Banks }\end{array}$ & $\begin{array}{c}\text { Local } \\
\text { Commercial } \\
\text { Banks }\end{array}$ & $\begin{array}{c}\text { Foreign } \\
\text { Bank } \\
\text { Branches }\end{array}$ & $\begin{array}{c}\text { Specialized } \\
\text { Banks }\end{array}$ \\
\hline Assets & 100.0 & 100.0 & 100.0 & 100.0 \\
\hline Total loans and discounts & 39.6 & 41.3 & 36.1 & 62.4 \\
\hline In domestic currency & 34.3 & 39.8 & 20.4 & 61.4 \\
\hline In foreign currency & 5.4 & 1.5 & 15.7 & 1.0 \\
\hline Securities & 10.4 & 16.9 & 5.6 & 10.3 \\
\hline Foreign assets & 7.5 & 2.2 & 8.5 & 1.2 \\
\hline other 1 & 42.5 & 39.6 & 49.8 & 26.1 \\
\hline Liabilities and net worth & 100.0 & 100.0 & 100.0 & 100.0 \\
\hline Deposits and CDs & 51.1 & 56.9 & 9.8 & 69.6 \\
\hline Domestic currency deposits & 35.8 & 46.4 & 2.1 & 58.6 \\
\hline Foreign currency deposits & 7.9 & 2.9 & 0.7 & 1.3 \\
\hline CDs & 7.4 & 7.7 & 7.0 & 9.72 \\
\hline BOK borrowing & 5.1 & 4.3 & 0.0 & 3.3 \\
\hline Government borrowing & 0.3 & 0.2 & 0.0 & 9.3 \\
\hline Foreign liabilities & 4.5 & 0.4 & 50.6 & 0.3 \\
\hline Other $3 /$ & 39.0 & 38.1 & 39.5 & 17.4 \\
\hline
\end{tabular}

Source: Bank of Korea, Monthly Statistical Bulletin.

1/ Includes acceptances and guarantees, and net worth.

2/ Includes debentures which account for 5.1 percent of total assets.

3/ Includes net worth. 
Chart II.1. Korea: Financial Institutions in Korea 1 /

(End 1994)

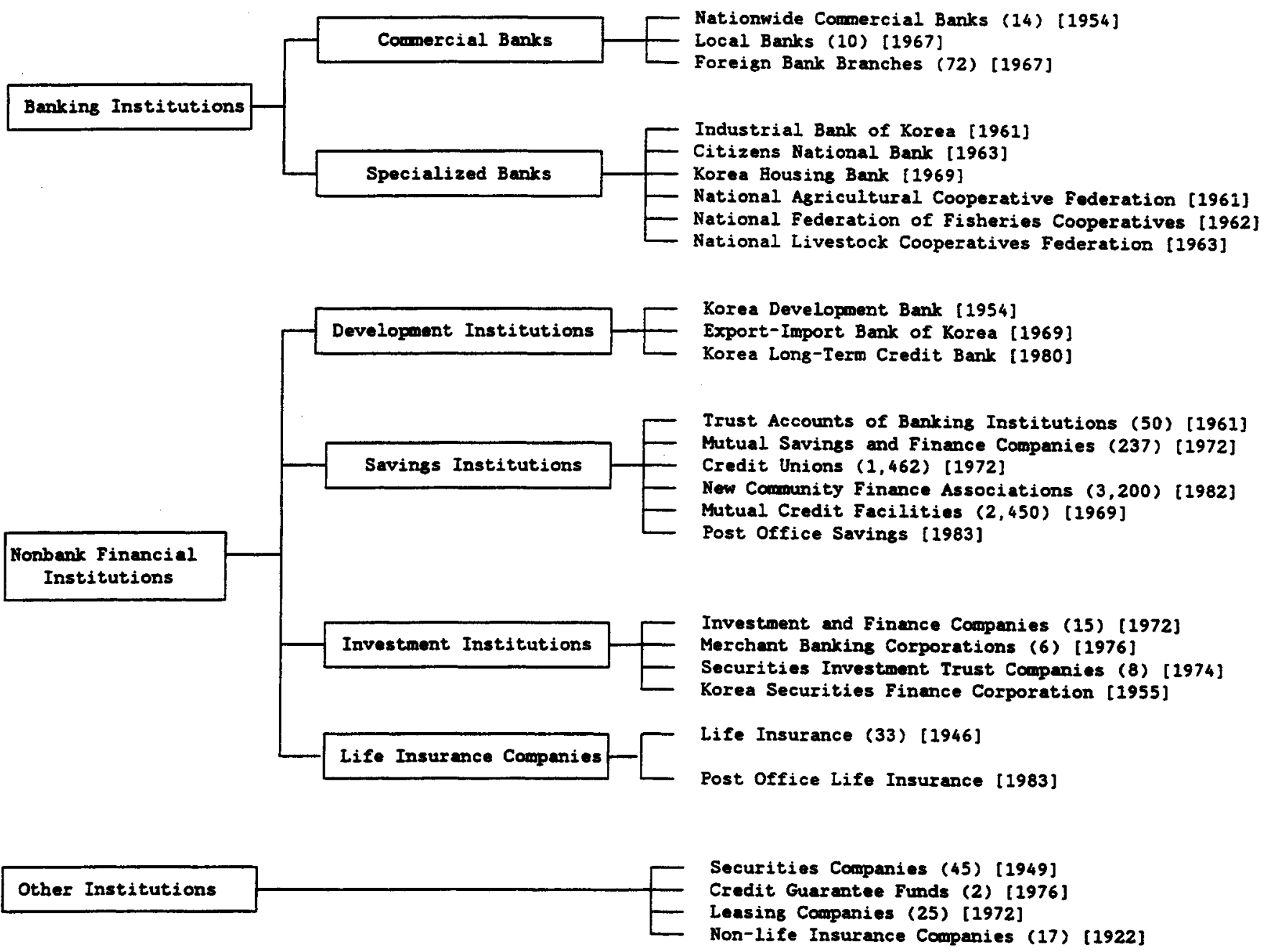

Source: Monetary Rolicy and Its Instruments, Bank of Korea, 1994.

1/ Figures in parentheses represent the number of institutions. Figures in brackets represent the year in which the institution was established. Where there is more than one institution in a group, the year refers to that of the first institution to be established. 
specialized banks. DMBs held nearly half of their assets in the form of loans and discounts in 1994, while securities and foreign assets accounted for 11 percent and 5 percent, respectively, of their assets.

Within the NBFI sector, four types of institutions can be distinguished: savings institutions, development institutions, investment companies, and life insurance companies. 1 / of these, savings institutions, such as mutual savings and finance companies, credit unions and mutual credit facilities, resemble banks closely in that they accept deposits from the public and grant loans (Table II.2). Development institutions, such as the Korea Development Bank (KDB), the Export-Import Bank of Korea (EXIMB), and the Korea Long-Term Credit Bank (KLCB), mainly provide long-term financing for targeted projects or sectors. Their main funding sources consist of government capital and lending, long-term debentures, and international promissory notes. Investment companies raise funds mainly by offering cash management accounts, borrowing, and issuing their own paper. They provide short-term financing to non-financial corporations and play an important role as brokers/dealers in money and capital markets.

Many NBFIs were established in the 1970 s in order to absorb funds from the curb market. While interest rates of both DMBs and NBFIs have been subject to regulation, NBFIs have been allowed to offer higher deposit rates to provide attractive investment alternatives to the curb market. As a result, the share of NBFIs in total deposit increased rapidly while the market share of DMBs, both commercial banks and specialized banks, declined (Table II.3). By the mid-1980s, the downward trend in the market share of DMBs had become so pronounced that they were permitted to compete with NBFIs through special NBFI subsidiaries offering trust banking services. Responding to the favorable regulatory conditions, money in trust doubled its share in total deposits from 8 percent in 1985 to 16 percent in 1990, while the market share of traditional DMB deposits continued to decline.

\section{c. Money and bond markets}

Currently, nine categories of instruments are traded in the Korean money market: call money, monetary stabilization bonds (MSBs), treasury bills (TBs), commercial paper (CPs), negotiable certificates of deposit (CDs), repurchase agreements (RPs), commercial bills, trade bills, and, recently introduced, cover bills (Table II.4). While most of these instruments were introduced in the 1970s, they were subject to a variety of regulations regarding interest rates, maturities, and denominations, which impeded the development of the money market. In the 1980s, these regulations were gradually eased, and, in 1991, interest rates on most money market instruments were effectively liberalized.

1/ In addition, the financial sector includes a number of other financial institutions such as securities companies, leasing companies, and non-life insurance companies. 
Table II.2. Korea: Selected Nonbank Financial Institutions-Structure of Assets and Liabilities

(In percent of total assets: end-1994)

\begin{tabular}{|c|c|c|c|c|}
\hline & $\begin{array}{c}\text { Korea } 1 \\
\text { Development } \\
\text { Bank }\end{array}$ & $\begin{array}{c}\text { Mutual } \\
\text { Savings } \\
\text { and Finance }\end{array}$ & $\begin{array}{l}\text { Trust } \\
\text { Accounts } \\
\text { of Banks }\end{array}$ & $\begin{array}{c}\text { Investment } \\
\text { and Finance } \\
\text { Companies }\end{array}$ \\
\hline Assets & 100.0 & 100.0 & 100.0 & 100.0 \\
\hline Loans and discounts & 52.7 & 78.1 & 22.4 & 61.8 \\
\hline Securities & 11.3 & 4.3 & 67.9 & 8.3 \\
\hline other & 36.0 & 17.5 & 9.7 & 29.8 \\
\hline Liabilities and net worth & 100.0 & 100.0 & 100.0 & 100.0 \\
\hline Deposits & 15.4 & 77.7 & $\cdots$ & 52.8 \\
\hline Money in trust & - & - & $90.72 /$ & $\cdots$ \\
\hline Beneficiary certificates & -- & -- & -- & $\cdots$ \\
\hline Borrowing and debentures issued & 48.9 & 0.1 & -- & 13.9 \\
\hline Other $\underline{3}$ & 35.7 & 22.3 & 9.3 & 33.2 \\
\hline
\end{tabular}

Source: Bank of Korea, Monthly Statistical Bulletin.

1) The Korea Development Bank is the largest of the three development institutions. It accounted for over two thirds of their combined assets in 1994 .

2/ Includes securities investment trust accounts.

3 Includes net worth. 
Table II.3. Korea: Trends in the Market Share of Financial Institutions, 1970-94

(In percent)

\begin{tabular}{|c|c|c|c|c|c|c|c|c|c|}
\hline & 1970 & 1975 & 1980 & 1985 & 1990 & 1991 & 1992 & 1993 & 1994 \\
\hline \multicolumn{10}{|l|}{ Deposits } \\
\hline $\begin{array}{l}\text { Commercial banks } \\
\text { Specialized banks } \\
\text { Nonbank financial }\end{array}$ & $\begin{array}{l}55.3 \\
30.5\end{array}$ & $\begin{array}{l}54.6 \\
24.3\end{array}$ & $\begin{array}{l}43.8 \\
26.4\end{array}$ & $\begin{array}{l}31.4 \\
22.3\end{array}$ & $\begin{array}{l}24.2 \\
15.6\end{array}$ & $\begin{array}{l}23.2 \\
15.2\end{array}$ & $\begin{array}{l}20.3 \\
14.2\end{array}$ & $\begin{array}{l}17.7 \\
13.2\end{array}$ & $\begin{array}{l}17.3 \\
11.9\end{array}$ \\
\hline institutions & 14.2 & 21.1 & 29.8 & 46.3 & 60.2 & 61.6 & 65.5 & 69.1 & 70.8 \\
\hline \multicolumn{10}{|l|}{$\begin{array}{l}\text { Loans and discounts } \\
\text { Commercial banks } \\
\text { Specialized banks } \\
\text { Nonbank financial }\end{array}$} \\
\hline institutions & 22.2 & 26.9 & 35.4 & 41.2 & 54.7 & 56.3 & 57.9 & 59.9 & 61.4 \\
\hline
\end{tabular}

Source: Bank of Korea, Monthly Statistical Bulletin, various issues. 
Table II.4. Korea: Monoy Market Instrumonts

\begin{tabular}{|c|c|c|c|c|c|c|c|c|c|}
\hline & Call Money & $\begin{array}{l}\text { Monotary } \\
\text { Stabllisation } \\
\text { Bonds }\end{array}$ & $\begin{array}{l}\text { Treenury } \\
\text { Bills. }\end{array}$ & $\begin{array}{l}\text { Coumercial } \\
\text { Paper }\end{array}$ & $\begin{array}{l}\text { Cortifleates } \\
\text { of Doposits }\end{array}$ & $\begin{array}{l}\text { Ropurchese } \\
\text { Asrecononts }\end{array}$ & $\begin{array}{l}\text { Cormerciel } \\
\text { B111. }\end{array}$ & Trede B111s & Cover B1L1 \\
\hline Function & $\begin{array}{l}\text { Adjustment of } \\
\text { temporary } \\
\text { murpluses and } \\
\text { shorteges of } \\
\text { short-term } \\
\text { eunde smons } \\
\text { linancial } \\
\text { institutions }\end{array}$ & $\begin{array}{l}\text { Monetary } \\
\text { control } \\
\text { Inotrumont }\end{array}$ & $\begin{array}{l}\text { Plnenoing of } \\
\text { teaporary } \\
\text { government } \\
\text { deflelts } b /\end{array}$ & $\begin{array}{l}\text { Reisins of } \\
\text { chort-term } \\
\text { operatins } \\
\text { sunds for } \\
\text { elxm }\end{array}$ & $\begin{array}{l}\text { Expansion } \\
\text { of the doposit } \\
\text { base of banks }\end{array}$ & $\begin{array}{l}\text { Short-term } \\
\text { funde backed } \\
\text { by bonds }\end{array}$ & $\begin{array}{l}\text { Liquidity for } \\
\text { elrwe: } \\
\text { diversifi- } \\
\text { cetion of the } \\
\text { funding base } \\
\text { of banks }\end{array}$ & $\begin{array}{l}\text { Llquidity for } \\
\text { exportins } \\
\text { elres; } \\
\text { chamelling of } \\
\text { L/C beoked } \\
\text { bIlle }\end{array}$ & $\begin{array}{l}\text { Rofinancing } \\
\text { of ste loans }\end{array}$ \\
\hline Issuars 21 & $\begin{array}{l}\text { All Einancial } \\
\text { Institutions }\end{array}$ & Bank of Korea & $\begin{array}{l}\text { Miniatry of } \\
\text { Finance and } \\
\text { Econowy }\end{array}$ & $\begin{array}{l}\text { Corporationa, } \\
\text { IrCs. } \\
\text { eorehent } \\
\text { Banke }\end{array}$ & Bank: & Banks, SCs & Corporation: & Boldors of $\mathrm{L} / \mathrm{C}$ & $\begin{array}{l}\text { Danks, IPCs, } \\
\text { ITCs, } \mathrm{mCO}_{3}\end{array}$ \\
\hline Dealers/brokers & & $\begin{array}{l}\text { IfCs, ITCs. } \\
\text { scs }\end{array}$ & $\begin{array}{l}\text { IFCs, ITCs, } \\
\text { SCs }\end{array}$ & $\begin{array}{l}\text { IFCs and } \\
\text { Dorchent } \\
\text { Danks }\end{array}$ & $\begin{array}{l}\text { IFCs, SCs, and } \\
\text { werchent banks }\end{array}$ & scs & Banks & $\begin{array}{l}\text { Banks, IFCe, } \\
\text { and merchent } \\
\text { benke }\end{array}$ & IFCs, banks \\
\hline Investors & $\begin{array}{l}\text { Financial } \\
\text { inatitutions }\end{array}$ & Open & Open & Open & Opon & Open & Open & Open & \\
\hline Maturities & 1 15, 30 days & $\begin{array}{l}\text { Less than } \\
1 \text { year }\end{array}$ & $\begin{array}{l}\text { Less than } \\
1 \text { year }\end{array}$ & $30 \sim 270$ days & $30 \sim 270$ days & 30 days 1 year & 60 180 days & $60 \sim 180$ days & $1 \sim 180$ days \\
\hline $\begin{array}{l}\text { Denoninations: } \\
\text { (won) }\end{array}$ & $\begin{array}{l}\text { Over } \\
100 \text { million }\end{array}$ & $\begin{array}{l}\text { Over } \\
1 \text { million }\end{array}$ & $\begin{array}{l}\text { Over } \\
1 \text { million }\end{array}$ & Vary & $\begin{array}{l}\text { Over } \\
20 \text { million }\end{array}$ & Vary & Vary & Vary & $\begin{array}{l}10 \text { million } \\
\text { for banks } \\
\text { and Mco; } \\
5 \text { million } \\
\text { for IFC. ITC }\end{array}$ \\
\hline Interest rates & $\begin{array}{l}\text { Llberal- } \\
\text { leod } 3 /\end{array}$ & $\begin{array}{l}\text { Partly } \\
\text { liboral- } \\
\text { leod } 1 /\end{array}$ & $\begin{array}{l}\text { Liberal- } \\
\text { laed 5/ }\end{array}$ & $\begin{array}{l}\text { Liberallzed } \\
\text { for denomina- } \\
\text { tione of more } \\
\text { then } \\
\text { w } 20 \text { million }\end{array}$ & $\begin{array}{l}\text { Llberal- } \\
\text { Leed } 6 /\end{array}$ & $\begin{array}{l}\text { Liberal- } \\
\text { laed } Z \text { for } \\
\text { denominations } \\
\text { of more than } \\
\text { W } 20 \text { millition }\end{array}$ & $\begin{array}{l}\text { Ltberalleod } \\
\text { for donomina- } \\
\text { tions of more } \\
\text { than } \\
\text { W } 20 \text { million }\end{array}$ & $\begin{array}{l}\text { Liberalieed for } \\
\text { denominations } \\
\text { of more then } \\
W 20 \text { million }\end{array}$ & Ltberalleed \\
\hline
\end{tabular}

Sources: Bank of Korea, and Minlatry of Plnence and Economy; updatod by staff.

1/ Malnly used as monotary control Instrumonts.

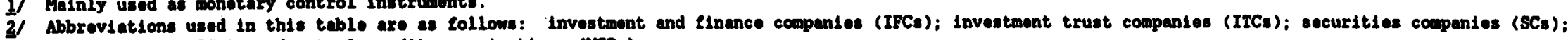
invurance compenies (ICs); and mutual credit organlzations (MCOA).

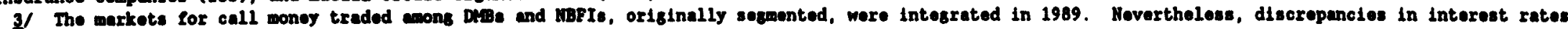
of 25 to 75 bass points have perselsted.

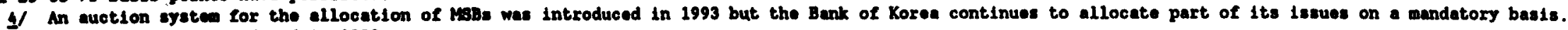

5/ An auction was introduced in 1993.

6f Restrictions on iesuo volives, maturities, and minimum denominations continue to apply.

If Restrictions on demominations and maturities very by issue.

CInternational Monetary Fund. Not for Redistribution 
As a result of the gradual liberalization of the regulatory environment, 1 / the money market expanded rapidly in the 1980s, both in terms of size and diversity (Table II.5). In the second half of the decade, the rapid growth of the money market reflected in large part the expansion of MSBs that were issued to sterilize the liquidity effects of large current account surpluses. Furthermore, CDs have accounted for a rapidly increasing segment of the market, while the relative importance of commercial paper, which dominated the market in 1980, has declined steadily. Since 1990, however, the expansion of the money market has lagged behind the growth of major monetary aggregates and its relative size has declined somewhat.

Korea has a sizable bond market with total outstanding bonds in 1994 amounting to some 40 percent of GDP. Various types of government and public bonds account for nearly two thirds of the outstanding volume and corporate bonds for somewhat more than one third. $2 /$ While some government and public bonds have maturities of five years or more, 3 / most bonds have relatively short maturities. In 1994, nearly all offerings of corporate bonds had maturities of four years or less. In addition, many corporate bonds are guaranteed by banks. While the share of guaranteed corporate bonds in total offerings has declined since the late 1980s, they still accounted for over 60 percent of new offerings in 1994. Most bonds are held by financial institutions, which accounted for 90 percent of total holdings in 1993. Notwithstanding the considerable volume of bonds outstanding, the secondary market is insignificant. 4 /

\section{Intermediate targets and indicators of monetary policy}

Monetary policy in Korea has traditionally been conducted by targeting monetary or credit aggregates. In the 1970 s, monetary policy was geared toward facilitating investment financing in order to achieve rapid growth, and domestic credit was used as an intermediate target. In the 1980s, the focus of monetary policy shifted toward price stabilization and $M 2$ became the principal intermediate target.

If In addition, technical improvements in the trading and settlement infrastructure--such as the introduction of a blind brokerage system for the call market, and, most recently, of the BOK wire system, which includes a large value gross settlement system for call money transactions-have enhanced the transparency and efficiency of trading and reduced transaction risks.

2/ Government and public bonds include national government bonds, state government bonds, state enterprise bonds and MSBs issued by the BOK. Although MSBs typically have maturities of one year or less and are considered money market instruments, they are generally included in bond market statistics. For a detailed description of the Korean bond market see World Bank (1995).

3/ Certain national housing bonds have a maturity of 20 years, the longest maturity of all government bonds.

4/ See World Bank 1995 for a description of the secondary market. 
Table II.5. Korea: Money Market Irends, 1980-94

(In billions of won, and percent) $1 /$

\begin{tabular}{|c|c|c|c|c|c|c|c|c|c|c|c|c|c|c|}
\hline & \multicolumn{2}{|c|}{1980} & \multicolumn{2}{|c|}{1985} & \multicolumn{2}{|c|}{1988} & \multicolumn{2}{|c|}{1990} & \multicolumn{2}{|c|}{1992} & \multicolumn{2}{|c|}{1993} & \multicolumn{2}{|c|}{1994} \\
\hline & Amount & Share & Amount & Share & Amount & Share & Amount & Share & Amount & Share & Amount & Share & Amount & Share \\
\hline Call market $2 /$ & 179 & 5.4 & 565 & 3.9 & 829 & 2.1 & 4,325 & 7.0 & 3,861 & 4.9 & 3,811 & 4.1 & 3,090 & 3.1 \\
\hline Commerolal paper & 2,083 & 63.3 & 7,283 & 49.7 & 12,331 & 31.9 & 22,741 & 36.8 & 24,072 & 30.5 & 29,805 & 32.3 & 28,049 & 28.0 \\
\hline $\begin{array}{l}\text { Short-term sovernment securities } \\
\text { Treasury bills } \\
\text { Monetary stabilization bonds }\end{array}$ & $\begin{array}{r}153 \\
150 \\
3\end{array}$ & $\begin{array}{l}4.7 \\
4.6 \\
0.1\end{array}$ & $\begin{array}{l}504 \\
504\end{array}$ & $\begin{array}{r}3.4 \\
-.4\end{array}$ & $\begin{array}{r}16,874 \\
1,500 \\
15,374\end{array}$ & $\begin{array}{r}43.7 \\
3.9 \\
39.8\end{array}$ & $\begin{array}{r}17,741 \\
2,500 \\
15,241\end{array}$ & $\begin{array}{r}28.7 \\
4.0 \\
24.7\end{array}$ & $\begin{array}{r}21,844 \\
1,580 \\
20,264\end{array}$ & $\begin{array}{r}27.7 \\
2.0 \\
25.7\end{array}$ & $\begin{array}{r}24,832 \\
630 \\
24,202\end{array}$ & $\begin{array}{r}26.9 \\
0.7 \\
26.2\end{array}$ & $\begin{array}{r}25,440 \\
100 \\
25,340\end{array}$ & $\begin{array}{r}25.4 \\
0.1 \\
25.3\end{array}$ \\
\hline Certlficates of deposits & & -- & 1,081 & 7.4 & 1,753 & 4.5 & 6,804 & 11.0 & 11,943 & 15.1 & 16,500 & 17.9 & 21,409 & 21.3 \\
\hline Commerclal bllls & 744 & 22.6 & 2,672 & 18.2 & 4,476 & 11.6 & 7,725 & 12.5 & 12,426 & 15.7 & 14,774 & 16.0 & 18,285 & 18.2 \\
\hline Repurchase agreements & 130 & 4.0 & 2,563 & 27.5 & 2,380 & 6.2 & 2,411 & 3.9 & 4,787 & 6.1 & 2,493 & 2.7 & 4,050 & 4.0 \\
\hline $\begin{array}{l}\text { Total } \\
\text { In percent of } M 2 \\
\text { In percent of } M 3 \\
\text { In percent of nominal GDP }\end{array}$ & $\begin{array}{r}3.289 \\
26.2 \\
18.3 \\
8.6\end{array}$ & $\underline{100.0}$ & $\begin{array}{r}\frac{14.668}{51.3} \\
26.5 \\
17.9\end{array}$ & 100.0 & $\begin{array}{r}38.643 \\
79.0 \\
32.1 \\
29.0\end{array}$ & 100.0 & $\begin{array}{r}61.747 \\
89.9 \\
31.2 \\
34.4\end{array}$ & 100.0 & $\begin{array}{r}78,933 \\
62.0 \\
26.5 \\
32.8\end{array}$ & $\underline{100.0}$ & $\begin{array}{r}92.215 \\
82.2 \\
26.0 \\
34.5\end{array}$ & 100.0 & $\begin{array}{r}100.323 \\
75.3 \\
22.7 \\
32.9\end{array}$ & 100,0 \\
\hline $\begin{array}{l}\text { Total excl. monotary stabili- } \\
\text { zation bonds } \\
\text { In percent of } M 2 \\
\text { In percent of } M 3 \\
\text { In percent of nominal GDP }\end{array}$ & $\begin{array}{r}3.286 .0 \\
26.2 \\
18.3 \\
8.6\end{array}$ & 99.9 & $\begin{array}{r}14.164 \\
49.6 \\
25.5 \\
17.3\end{array}$ & 96.6 & $\begin{array}{r}23.269 \\
47.5 \\
19.3 \\
17.5\end{array}$ & 60.2 & $\begin{array}{r}46.506 \\
67.7 \\
23.5 \\
25.9\end{array}$ & $\underline{75.3}$ & $\begin{array}{r}58.669 \\
60.9 \\
19.7 \\
24.4\end{array}$ & $\underline{74.3}$ & $\begin{array}{r}68.013 \\
60.6 \\
19.2 \\
25.5\end{array}$ & 73.8 & $\begin{array}{r}74.983 \\
56.3 \\
16.9 \\
24.6\end{array}$ & 74.7 \\
\hline $\begin{array}{l}\text { Momorandum items: } \\
\text { Ma } \\
\text { Nominal GDP }\end{array}$ & $\begin{array}{l}12,544 \\
17,962 \\
38,148\end{array}$ & & $\begin{array}{l}28,565 \\
55,450 \\
82,062\end{array}$ & & $\begin{array}{r}48,939 \\
120,359 \\
133,134\end{array}$ & & $\begin{array}{r}68,708 \\
198,124 \\
179,539\end{array}$ & & $\begin{array}{r}96,259 \\
298,277 \\
240,392\end{array}$ & & $\begin{array}{l}112,219 \\
354,933 \\
267,146\end{array}$ & & $\begin{array}{l}133,179 \\
442,663 \\
305,008\end{array}$ & \\
\hline
\end{tabular}

Sources: Data provided by the Ministry of Finance and Econorny; and Bank of Korea, Economic Statistics Yearbook.

1/ Outstanding balances at and of poriod except for call market.

$\underline{2}$ f Average daily transactions from December 23 to Januery 7 of the following year. 
M2 growth has been used as the intermediate target of monetary policy since 1979 (see Box). The selection of M2 was based on empirical findings which suggested a relatively stable relationship between the M2 aggregate and nominal income (Chart II.2). 1/ Moreover, M2 proved to be easier to control than broader monetary aggregates, such as M3. With few exceptions, growth targets for M2 have generally been expressed in terms of target ranges (Table II.6). From 1979 to 1990, these targets applied to annual average growth rates. Since 1991 they have been defined in terms of the December over December average in order to permit greater flexibility in for monetary policy in the course of the year. Consistent with the Government's objective of bringing inflation down to partner country levels over the medium term, the target range for $M 2$ growth has been gradually lowered in recent years.

The Monetary Board sets annual M2 targets consistent with the Government's overall macroeconomic management plan. 2/ In essence, the determination of the target is based on a modified quantity equation $(M * V=P * Y)$, which allows for changes in velocity, with projections for the main macroeconomic variables as inputs. In addition, the BOK makes use of more sophisticated money demand equations as well as detailed flow of funds projections. Once the M2 target range for the year has been determined, the BOK prepares detailed quarterly plans for monetary management, taking into account seasonal fluctuations in money demand, developments in government expenditures and revenues, as well as prospects for trade and capital flows.

In the early years of M2 targeting (1979-92), M2 growth tended to overshoot the targets by significant margins. Since 1983, however, the Bank of Korea has generally succeeded in keeping M2 growth within or close to the target range--with the notable exception of 1990 , when monetary policy shifted to an expansionary stance following a sharp slowdown in activity in 1989. The increased flexibility afforded by the switch in 1991 from an annual average growth target to a 12 -month growth target for December has enabled the BOK to accommodate unforeseen shifts in $M 2$ demand, such as the temporary increase in money demand following the introduction of the real name system for financial transactions in 1993. As a result, the variability of $M 2$ growth in the course of the year has increased and annual average growth rates have differed substantially from the 12 -month rates for December, both in 1993 and 1994 (Chart II.3).

While Korea's experience with M2 targeting has generally been positive, the question arises whether M2 continues to be the most suitable intermediate target for monetary policy. With NBFI liabilities expanding at a much faster rate than DMB liabilities, the relative size of $\mathrm{M} 2$, which

1/ See Tseng and Corker (1991) and Hur (1991) for a discussion of the stability of alternative money demand functions for Korea.

2/ See Bank of Korea (1995) for a detailed description of the process of determining $M 2$ targets. 
Table II.6. Monotary Targets and Outcomes, 1979-95

(Peroent chanse of (y?) 1

\begin{tabular}{|c|c|c|c|c|c|c|c|c|c|c|c|c|c|c|c|c|c|}
\hline & 1979 & 1980 & 1981 & 1982 & 1983 & 1984 & 1985 & 1986 & 1987 & 1988 & 1989 & 1990 & 1991 & 1992 & 1993 & 1994 & 1995 \\
\hline Outcomo & 26.8 & 25.8 & 27.4 & 28.1 & 19.5 & 10.7 & 11.8 & 16.8 & 18.8 & 18.8 & 18.4 & 21.2 & 18.3 & 18.6 & 17.3 & 17.6 & 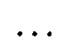 \\
\hline Upper bound & 25.0 & 20.0 & 25.0 & 22.0 & 20.0 & 13.0 & 14.0 & 18.0 & 18.0 & 18.0 & 18.0 & 19.0 & 19.0 & 18.5 & 17.0 & 17.0 & 16.0 \\
\hline Lower bound & 25.0 & 20.0 & 25.0 & 20.0 & 18.0 & 11.0 & 9.5 & 12.0 & 15.0 & 18.0 & 16.0 & 15.0 & 17.0 & 18.5 & 13.0 & 14.0 & 12.0 \\
\hline
\end{tabular}

Source: Bank of Korea.

1/ From 1979 to 1990 , the figures refer to annual average srowth rates; from 1991 onwerd, they refer to the 12 -month growth rate of the December average. 


\section{Box. Rorea: Composition and Developments of Monetary Aggregates} and $M 3$.

The main monetary aggregates are observed in Korea are M1, M2, M2A,

M1 includes currency in circulation and demand deposits held at deposit money banks.

M2 consists of M1 plus time deposits, savings deposits, and residents' foreign currency deposits held at deposit money banks. I/

$\mathrm{M} 2 \mathrm{~A}$ is a narrower, more transaction oriented version of $\mathrm{M} 2$. It excludes long-term time deposits and savings deposits with maturities of more than two years.

M3 is the broadest aggregate. In addition to M2 it includes deposits of nonbank financial institutions, as well as debentures issued, commercial bills sold, certificates of deposit, repurchase agreements, and, since July 1994, cover bills.

Partial liberalization of the financial sector since the early 1980 s has been reflected in a strong expansion of less regulated financial instruments that are excluded from the M1 and $M 2$ aggregates (Chart). Thus, while the increases in the ratios of M1 and M2 to nominal GDP have been relatively moderate, M3 grew from 40 percent of GDP in 1980 to nearly 150 percent of GDP in 1994.

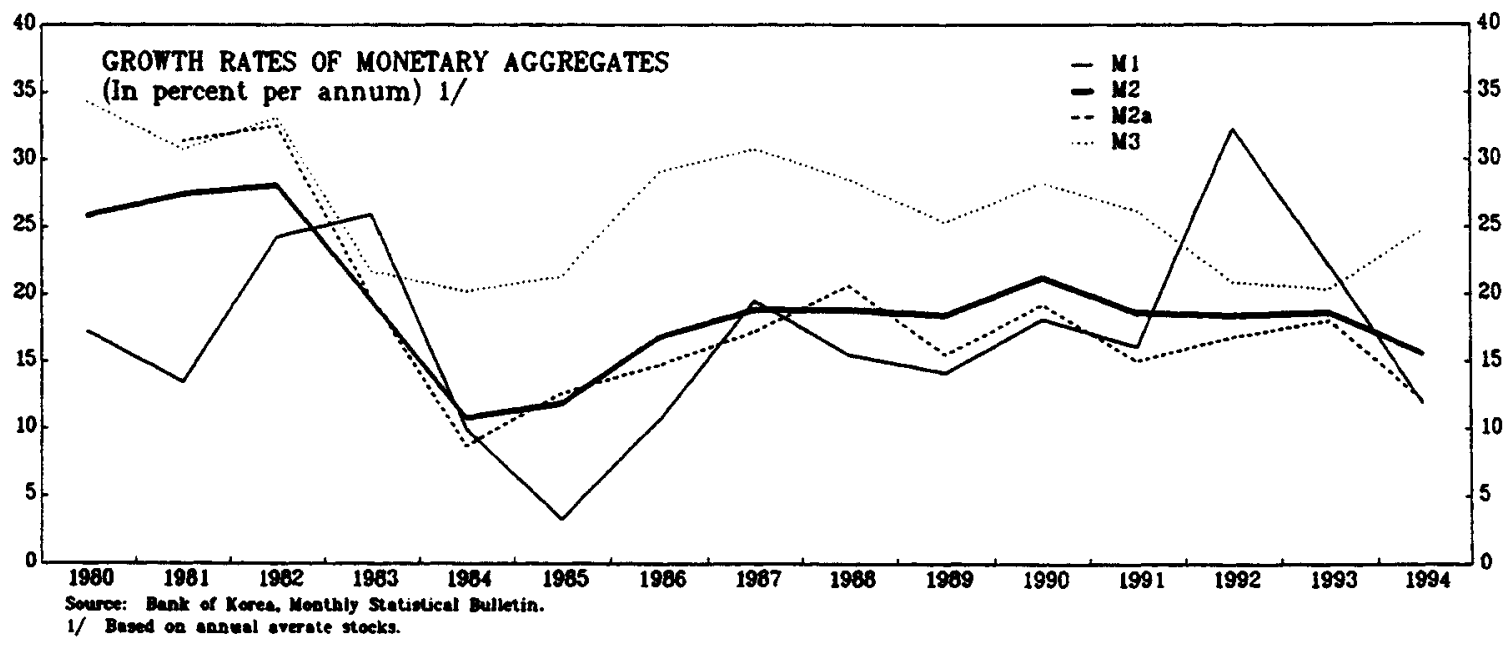

1 Another less commonly referred to aggregate is M2B. M2B consists of M2A plus certificates of deposit and repurchase agreements of deposit money banks, as well as short-term liabilities of NBFIs. 
CHART 11.2

KOREA

INCOME VELOCITY OF MONEY, 1980-94
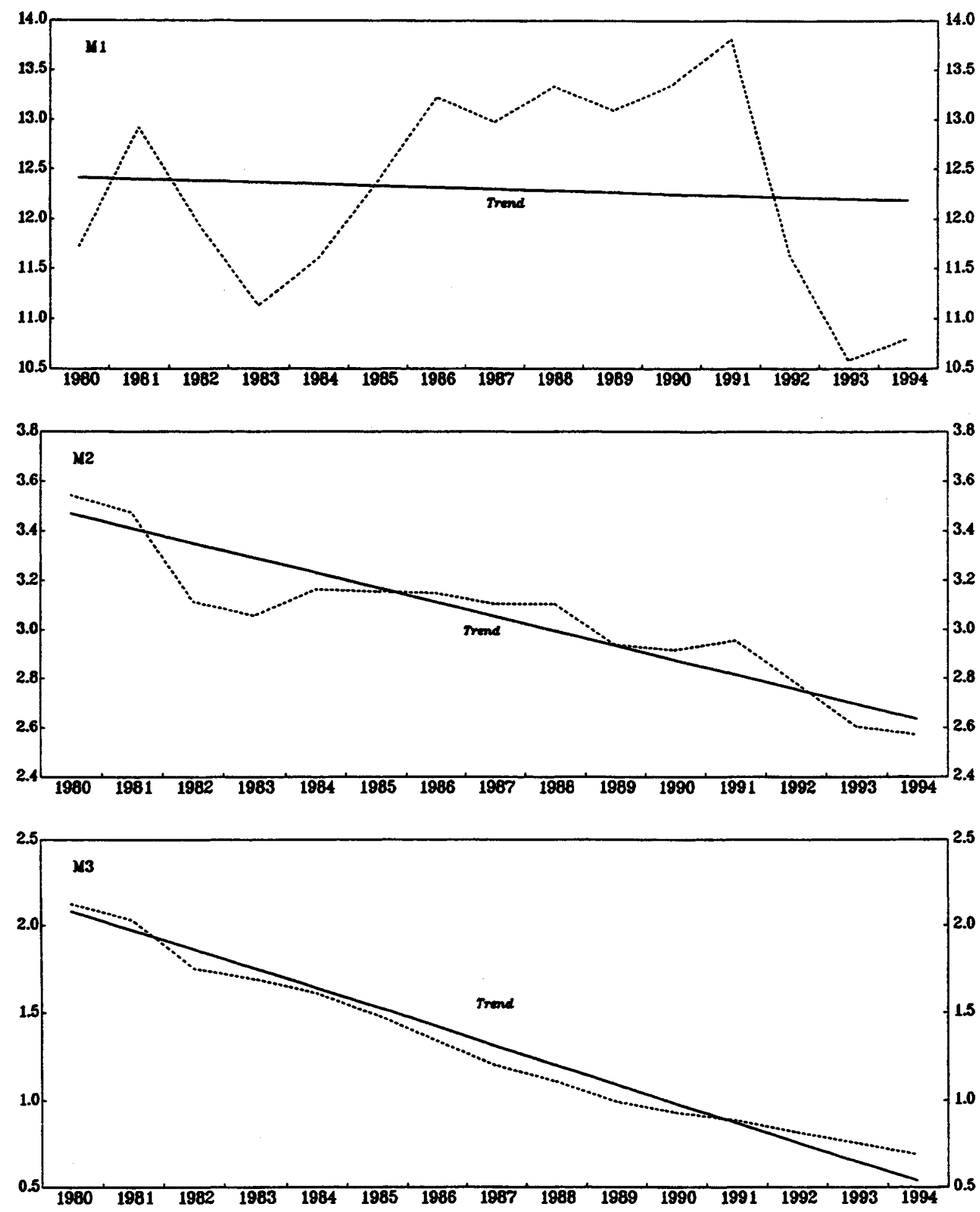

Sources: IMF, International Financial Statistics and Bank of Korea, Nontbly Statistical Bulletin. 


\section{M2 GROWTH AND TARGET RANGES, 1988-95}

(12-month percentage change) $1 /$

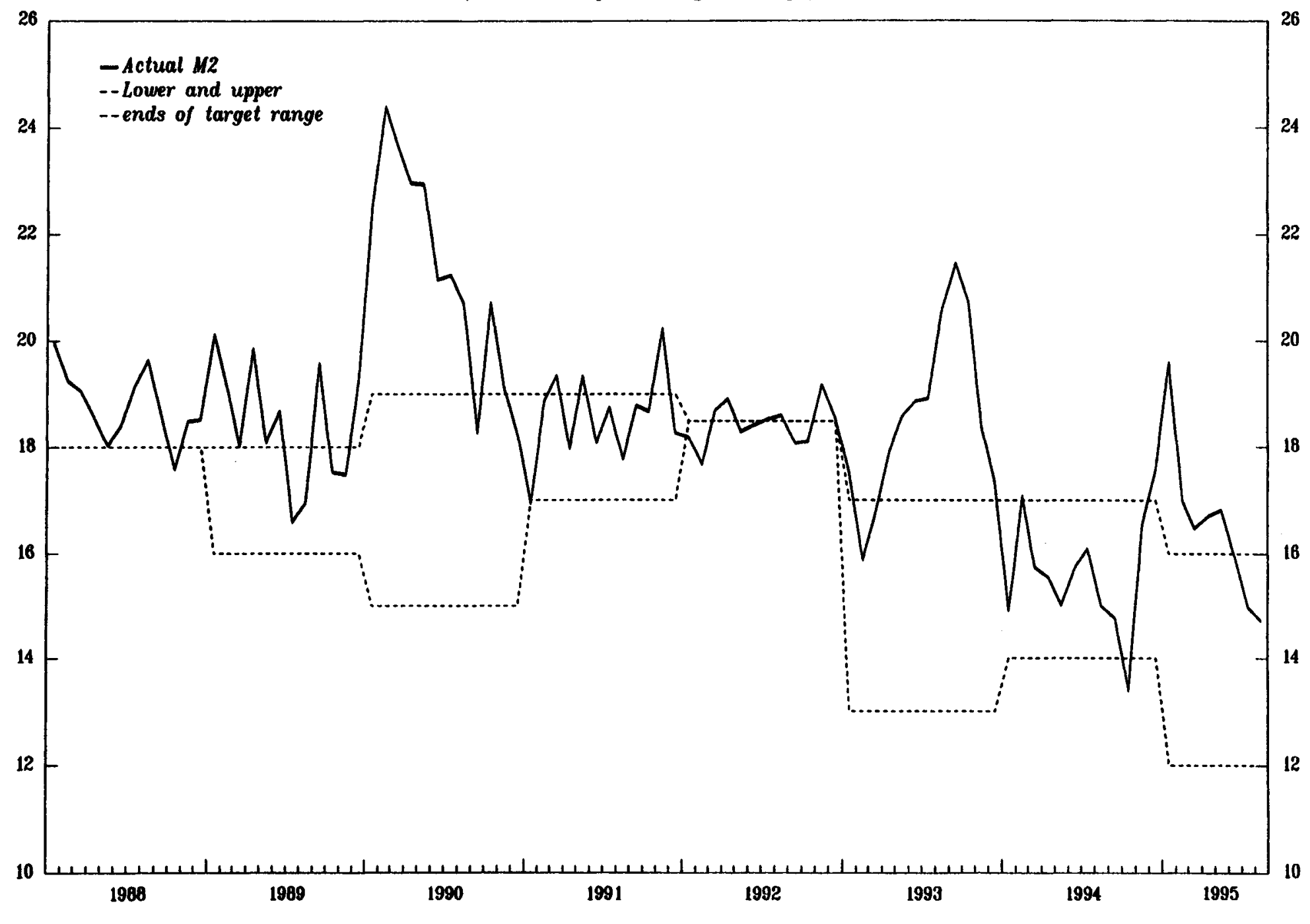

Source: Bank of Korea, Monthly Statistical Bulletin; data provided by the Korean authorities; and staff calculations. 
includes only the latter, has declined steadily since the early 1980s.

Moreover, the stability of M2 demand is likely to be affected by the ongoing process of financial sector liberalization. In principle, broader monetary aggregates such as $M 3$, which cover a large variety of financial instruments, are less likely to be influenced by portfolio shifts than narrower aggregates. In practice, however, M3 continues to be difficult to control, because it includes a large share of NBFI liabilities which are beyond the BOK's sphere of influence. With the choice of alternative intermediate targets thus effectively limited to modified versions of M2 or narrower aggregates, M2 has been retained as the principal intermediate target, albeit on a more flexible basis than in the past. In addition, other monetary aggregates, such as MI and M3, have been used as supplementary indicators.

With most interest rates subject to some form of control or window guidance, interest rates have played a subordinate role as monetary indicators. The yield of 3-year corporate bonds, which is determined freely in the relatively narrow secondary market, has generally been used as an indicator of developments in market determined interest rates. In addition, interest rates on different money market instruments, some of which were liberalized only in the early 1990s, have become more important in recent years (Chart II.4). While the primary focus continues to be on the M2 aggregate, on a number of occasions, notably in mid 1993 and in late 1994, the BOK has accepted deviations from its monetary targets in order to contain increases in interest rates.

\section{Operating procedures of monetary policy}

\section{a. The evolution of operating procedures}

The operating procedures used by the BOK to control the money supply have been determined by the limitations of available monetary policy instruments as well as shifts in the main sources of money growth. In the 1970s, monetary growth was dominated by the expansion of domestic credit, while the foreign sector absorbed liquidity (albeit generally on a moderate scale). Monetary policy relied mainly on credit ceilings and changes in reserve requirements to control monetary expansion. 1/ As the BOK's discount window was used primarily to refinance policy-based lending, rediscount policy could not be employed as a monetary control instrument. Open market operations were constrained by the limited availability of suitable government debt instruments and the underdeveloped money market.

In the 1980s, facilitated by the broadening and deepening of the money market and the scaling back of policy-based lending, the operating procedures of monetary policy gradually changed with the BOK relying increasingly on indirect instruments such as open market operations. Open

1) During 1970-77, domestic credit was in fact used as an intermediate target of monetary policy. In 1978 it was replaced by $M 1$ and in 1979 by $M 2$. 
market operations increased sharply in the second half of the 1980 s as the current moved into surplus and increases. in net foreign assets became an important source of liquidity growth (Chart II.5). In order to sterilize the excess liquidity, the BOK resorted to issuing large amounts of MSBs. 1/ In addition, the BOK raised minimum reserve ratios and introduced, on a temporary basis, marginal reserve requirements. Credit ceilings in the form of guidelines on the credit extension of individual banks were removed in late 1988. $2 /$

\section{b. Current operating procedures}

While current operating procedures of the BOK are mainly based on indirect monetary control instruments, non-market elements persist. In particular, open market operations, which have become the main instrument for the control of reserve money, continue to rely partly on mandatory allocations.

The main instruments used for open market operations are MSBs and RPs. While other financial instruments--such as treasury bills and Foreign Exchange Stabilization Fund Bonds-have also been employed, their role has been limited by their small volume. Open market operations in RPs involving government or public bonds were introduced in 1989. They are conducted exclusively with DMBs in order to control short-term bank liquidity. Very short-term RPs with maturities ranging from 2 to 3 days are used to finetune DMB reserves, while long-term RPs with maturities of 7 to 15 days are intended to absorb (cover) less temporary reserve surpluses (shortages) and to signal the BOK's intention to gradually tighten or loosen the monetary stance.

As noted above, placements of MSBs became an important instrument of liquidity control in the second half of the 1980s. MSBs are issued by the BOK with maturities ranging from 63 days to 546 days (with 364-day bonds dominating the market). 3/ In contrast to RPs, MSBs are also sold to NBFIs, which held nearly half of total outstanding MSBs at the end of 1994. MSBs have mainly been used to absorb non-temporary excess liquidity in the financial system, in particular liquidity arising from increases in net foreign assets. Thus, the outstanding amount of MSBs rose sharply during 1985-88 as the balance of payments registered large surpluses, declined during 1989-91 as the external position weakened, and increased again during

1. These placements of MSBs differed from conventional open market operations in that they were done on a mandatory basis and not at market interest rates.

2/ The evolution of the operating procedures of monetary policy in Korea is described in Bank of Korea (1993).

3) The Monetary Board determines the maximum amount of MSBs that can be issued by the BOK. The amount of MSBs outstanding peaked at 31 percent of M2 in 1988 and declined to 19 percent of M2 at the end of 1994 . 
KOREA

DEVELOPMENTS IN MARKET-DETERMINED INTEREST RATES, 1989-95

(Percent per annum)

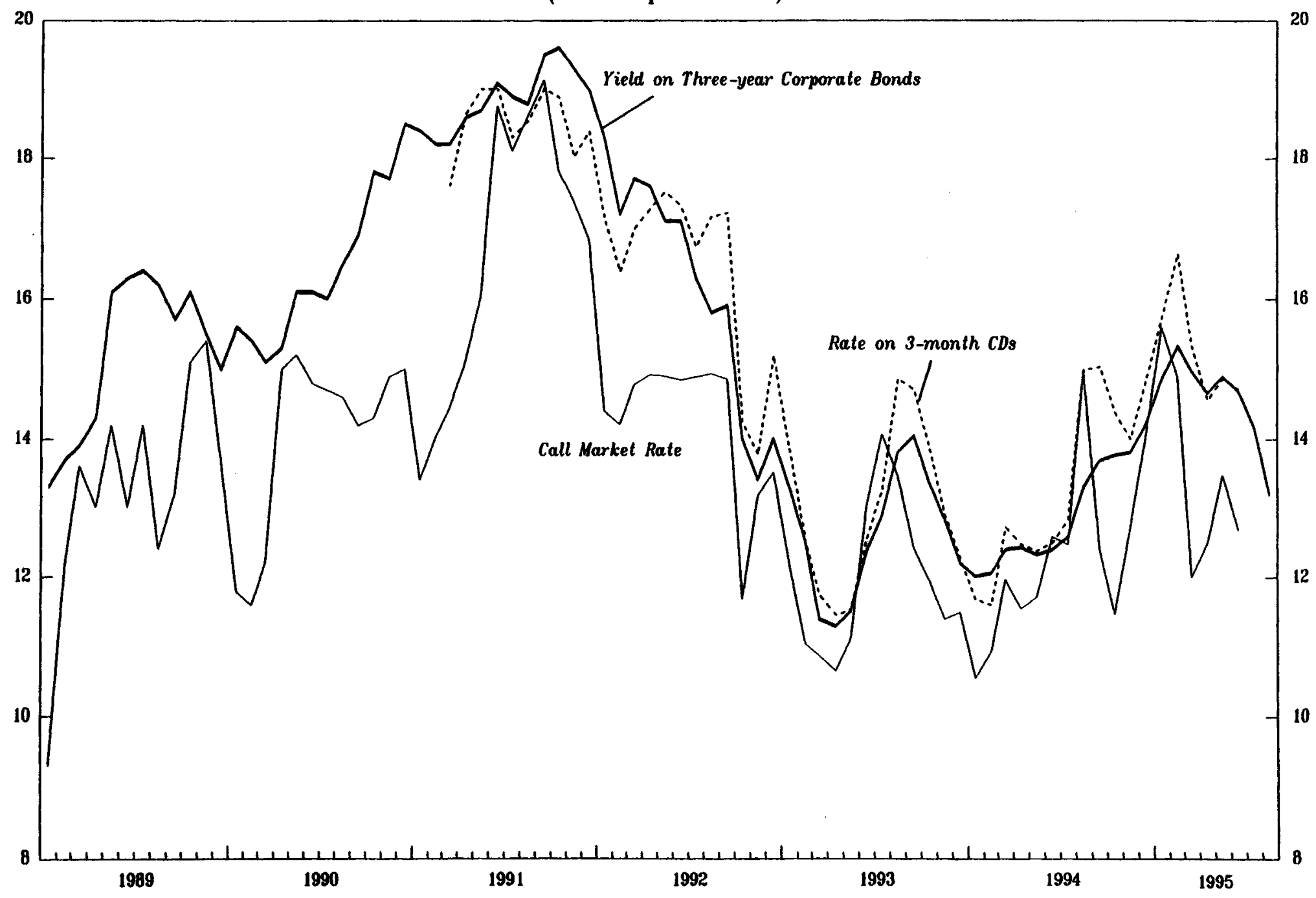

Source: Bank of Korea, Monthly Statistical Bulletin. 
(12-month percentage change) $1 /$

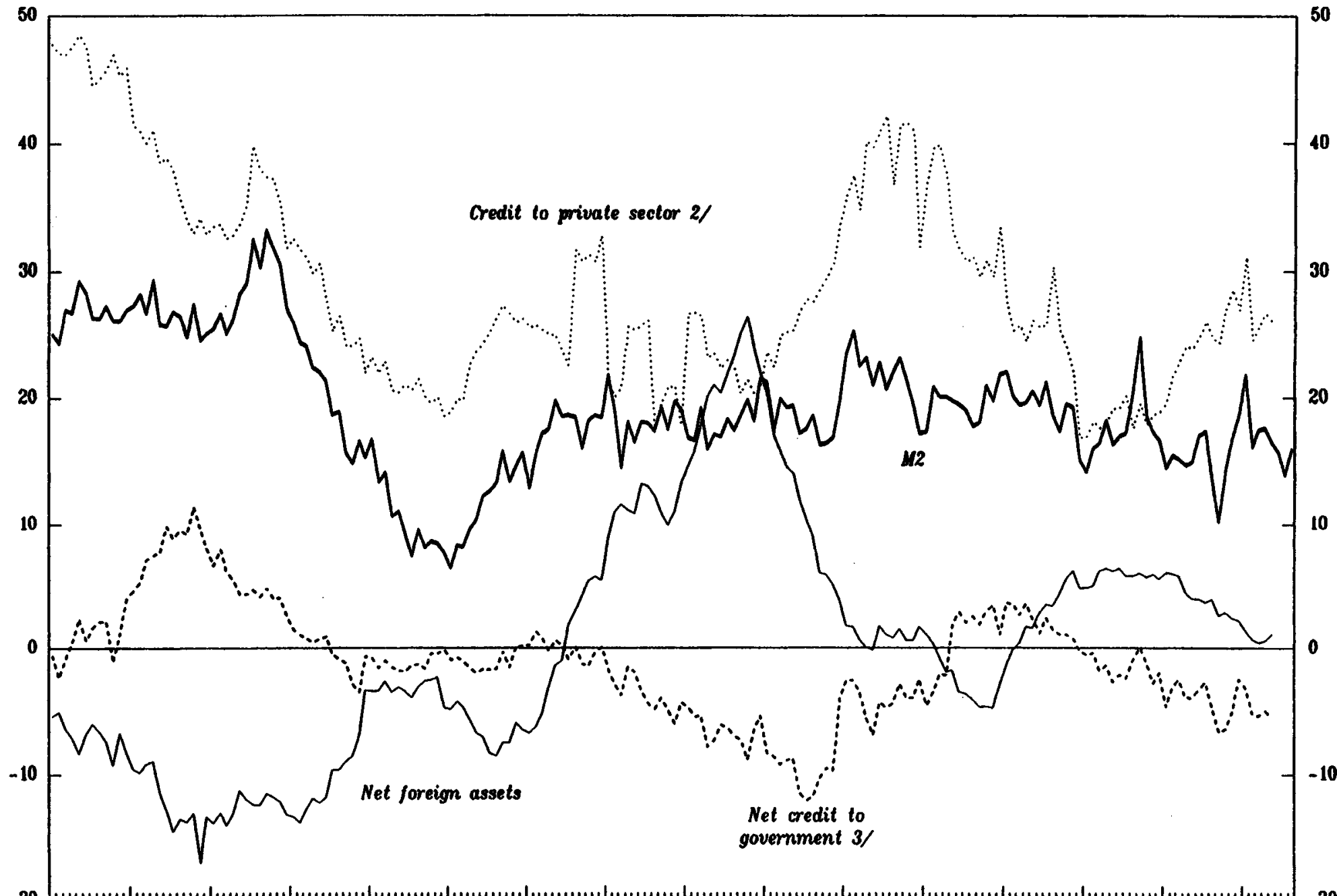

Source: Bank of Korea, Monthly Statistical Bulletin; data provided by the Korean outhorities; and staff calculations.

1/ End of period.

2/ Consists of claims on private sector, claims on other financial institutions, and claims on official entities.

3/ Consists of claims on government and government agencies.

\author{
CInternational Monetary Fund. Not for Redistribution
}


1992-94 as capital inflows necessitated significant sterilization operations.

While in the past RPs and MSBs were allocated on a mandatory basis, since March 1993, long-term RPs 1/ and 364-day MSBs have been sold through an auction process which resembles a Dutch auction. $2 /$ Based on the current level of the call market rate, the BOK determines a reservation price (maximum accepted yield) for RP auctions. All acceptable bids are executed at a single price determined by the BOK. If the volume of accepted bids does not match the desired transaction volume, the gap is closed by means of mandatory allocations at an interest rate which is usually five basis points below the rate fixed in the auction process. MSBs with 364-day maturity are auctioned in a similar fashion, with 64 primary dealers (DMBs and NBFIs) participating in the bidding. In the first five months of 1995 , nearly one third of all MSBs were still allocated on a mandatory basis. $3 /$ The Government's financial sector reform program envisages a gradual phasing out of such mandatory allocations.

Owing to the automatic rediscounting of policy loans at interest rates well below market rates (currently 5 percent), the BOK's discount window has not been actively used as an instrument of monetary control in Korea. 4/ Discount policy has generally been limited to altering the eligibility criteria and discount ratios for the refinancing of policy loans. However, in order to enhance the system of monetary control, the Government plans to change the role of discount policy by gradually relieving the BOK of the responsibility for the refinancing of policy loans and by permitting greater flexibiiity in setting the discount rate. As envisaged in the financial sector reform program, an aggregate ceiling for the refinancing of policy loans was introduced in March 1994. 5/ The ceiling is set on a quarterly basis by the Monetary Board in light of prevailing monetary conditions. Within the overall ceiling, the BOK allocates available discounts among DMBs on the basis of their past lending activities. Following the introduction of the ceiling system, outstanding loans and discounts of the Bank of Korea fell from W 16.5 trillion in 1993 to W 14 trillion in 1994.

1/ Short-term RPs are sold/bought directly at prices fixed by the BOK.

2) In a Dutch auction, bidders either congregate in one room or interact electronically. The auctioneer begins with calling an unreasonably high price (or low yield) and then progressively lowers the price until the entire stock is sold or a reservation price is reached (see Bartolini and Cottarelli (1994)).

3/ These mandatory allocations involved MSBs with shorter maturities which are not yet being auctioned.

4/ In 1994 the refinancing of policy loans accounted for almost 80 percent of total outstanding loans and discounts of the BOK.

5/ The ceiling applies to rediscounts of commercial and trade bills. Refinancing of policy loans to the agricultural, forestry and fisheries sectors remains outside the ceiling. 
While in the 1980 s the BOK used changes in reserve requirements and their enforcement to influence monetary conditions, required reserve ratios have remained unchanged since 1990. A required reserve ratio of 11.5 percent applies to all demand, time and savings deposits of DMBs, I/ with the exception of certain long-term time and savings deposits with lower, preferential reserve ratios. 2/ Required reserves are calculated semi-monthly. In order to give DMBs time to adjust their reserve position, the reserve maintenance period lags the computation period by seven days. If actual reserves fall short of required reserves, the BOK can impose a penalty or extend a temporary liquidity. loan (B2 loan), which carries a penalty interest rate (call rate plus 2 percent), as well as an obligation for the receiving bank to adjust its balance sheet. While NBFIs are not formally subject to reserve requirements, they are obliged to hold against a certain share their deposits MSBs at below-market interest rates.

Given the limited flexibility of reserve requirements and the limitations of rediscount policy, the BOK relies essentially on RP and MSB operations in order to influence bank reserves, which are used as an operational target in its day-to-day operations. Based on the monthly growth target for $M 2$, the BOK calculates targets for DMB reserves twice a month. At the same time, the expected level of reserves is forecast, taking into account historical trends in reserves, as well as expected developments in government accounts and foreign assets and liabilities. If projected reserves diverge from the target, open market operations are used to withdraw or inject liquidity.

\section{Summary}

Institutional framework, intermediate targets, and operating procedures of monetary policy in Korea have changed significantly in the past two decades. With the gradual liberalization of the financial sector, nonbank financial institutions have expanded rapidly and financial markets have been broadened and deepened. The focus of monetary policy shifted, from supporting investment and growth through extensive policy-based lending, toward price stabilization through control of monetary growth. Operating procedures, once heavily reliant on direct policy instruments such as credit ceilings, have increasingly been based on indirect instruments, notably open market operations in RPs and MSBs.

1) The same reserve requirements are imposed on KDB and KLCB deposits.

2/ Deposits with preferential reserve ratios include workman's savings for housing ( 3 percent), housing installment deposits ( 3 percent), mutual installment deposits ( 3 percent), workman's property formation ( 3 percent), as well as time and installment savings deposits with maturities exceeding

2 years and household preferential installment savings deposits (all

8 percent). Foreign currency deposits held by non-residents are subject to

a required reserve ratio of 1 percent. 
Since 1979, monetary policy in Korea has focussed on M2 growth as the principal intermediate target. While the experience with this approach has generally been positive, monetary targeting in recent years has been complicated by structural changes in the financial system resulting from gradual deregulation, notably the liberalization of interest rates. In order to accommodate unforseen shifts in money demand, the BOK has adopted a more flexible approach to monetary targeting, while retaining M2 as an intermediate target.

The medium-term objective of monetary policy is to bring inflation down to partner country levels. At the same time, a reform of operating procedures is under way, which envisages the gradual phasing out of the remaining nonmarket elements in the present system, such as mandatory allocations of open market instruments. As part of its financial sector liberalization program, the Government plans to move to a fully market-based system of monetary control. 


\section{References}

Bank of Korea, Annual Report, various issues.

(1990), Financial System in Korea.

(1993), Monetary Policy and its Instruments in Korea, Research Department.

(1995), Monetary Management Policies and Procedures in Korea, Research Department.

Bartolini, L., and C. Cotarel1i (1994), "Treasury Bill Auctions: Issues and Uses, " IMF Working Paper, WP/94/135.

Cho, Yoon-Je, and T. Hellmann (1994), "The Government's Role in Japanese and Korean Credit Markets: A New Institutional Economic Perspective," Seoul Journal of Economics, Vol. 7, pp. 383-415.

Frankel, J. A. (1994), Recent Changes in the Financial Systems of Asian and Pacific Countries, mimeo.

Hur, Jae-Sung (1991), Financial Market Liberalization and its Effects on the Velocity of Money in Korea, mimeo.

International Monetary Fund, "Korea--Market Liberalization and Macroeconomic Policies," SM/90/188, 9/26/90.

, "Korea--Recent Economic Developments," SM/94/28, 1/31/94.

, "Korea--Recent Economic Developments," SM/94/229, 8/29/94.

Jwa, Sung-Hee (ed.) (1993), "Korea--Market Liberalization and Macroeconomic Policies Monetary and Financial Policy Reforms: European Experiences and Alternatives for Korea," Papers and Discussions from a Joint KDI/FES Conference, Seoul.

Kang, Moon-Soo (1990), "Money Market and Monetary Policy in Korea," Korea Development Institute, Working Paper No. 9020.

Marquardt, J. C. (1994), "Monetary Issues and Payment System Design," (ch. 4), and "Payment System Policy Issues and Analysis," (ch. 9), in B. J. Summers (ed.), The Payment System: Design. Management and Supervision, International Monetary Fund.

Meulendyke, A. M. (1992), "Reserve Requirements and the Discount Window in Recent Decades," Federal Reserve Bank of New York Ouarterly Review, pp. 25-43. 
Nam, Sang-Woo (1992), "Korea's Financial Reform Since the Early 1980s," Korea Development Institute, Working Paper No. 9207.

OECD (1994), Country Study: Korea, Paris.

Park, Yung-Chul (1994), "Korea: Development and Structural Change of the Financial System," in H. T. Patrick and Yung-Chul Park (eds.), The Financial Development of Japan. Korea, and Taiwan: Growth. Repression, and Liberalization, New York.

Ro, Sung Tae (1994), "Korean Monetary Policy," in S. Haggard et al. (eds.), Kacroeconomic Policy and Adjustment in Korea, 1970-1990, Harvard Institute for International Development.

Tseng, W., and R. Corker (1991), "Financial Liberalization, Money Demand, and Monetary Policy in Asian Countries," IMF Occasional Paper, No. 84.

World Bank (1993), "Korea Financial Sector Study," World Bank Report No. 11373-KO. (1995), "The Emerging Asian Bond Market--Korea," June. 


\section{Financial Sector Reform and External Capital Account Opening 1}

\section{Introduction}

Financial institutions in Korea have traditionally played a key role as a vehicle of industrial policy based on preferential financing. This policy spawned a host of government regulations and interventions, which hampered the development of an efficient and competitive financial sector. In the 1980 s the drawbacks of the system became increasingly evident; giving rise to a series of selective liberalization measures. However, given the limited scope of these measures, financial sector development continued to lag behind the rest of the economy, prompting efforts to broaden and deepen the reform process. In the early 1990s, financial sector deregulation and capital account opening thus became top priorities for structural policies, and in 1993 a comprehensive, multi-year reform plan was presented.

This chapter reviews the process of financial sector liberalization and capital account opening in Korea. Section 2 provides a brief overview of the evolution of financial sector reform since the early 1980 s, while sections 3 and 4 focus on the main elements of the current reform program. Section 3 reviews reforms in the domestic financial sector, and section 4 discusses capital account liberalization and exchange reform. Section 5 summarizes the findings.

\section{Financial sector reform since the early 1980s: an overview}

In the 1960s and particularly in the 1970s, the main objective of financial sector policies was to channel credit at preferential interest rates to targeted sectors. The Government influenced the sectoral allocation of credit through direct government control over commercial and specialized banks, which at the time were state-owned, the Bank of Korea's (BOK's) rediscount facility, and control over foreign borrowing. Interest rates were regulated, financial innovation was restricted, and entry barriers were high to limit competition. Nevertheless, in order to absorb the sizable informal credit market, the Government in the 1970s permitted the establishment of new, less regulated and privately-owned financial institutions. These institutions quickly developed into a thriving nonbank financial sector, whose share in total deposits rose from 21 percent in 1975 to 71 percent in $1994.2 /$

In the late 1970s, the costs of extensive policy-based lending - inefficiencies in credit allocation and inadequate monetary control--became increasingly evident and prompted a move toward partial liberalization. $3 /$

1) Prepared by Harald Hirschhofer with assistance from

Eduardo Borensztein and Marianne Schulze-Ghattas .

2/ See Table II.3, chapter II.

3/ An overview of financial sector reforms in the 1980 s is included in OECD (1994), and Nam (1992). 
In the 1980s, commercial banks were privatized (1981-83), several new banks were allowed to enter the market, and restrictions on the business activities of bank and nonbank financial institutions were eased. While the Government continued to influence credit allocation through rediscount policy, the lending policies of government-owned special banks, $1 /$ and special lending requirements, $2 /$ the degree and scope of such interventions were scaled back.

In order to further the development of financial markets, a number of new financial instruments, such as repurchase agreements (RPs), certificates of deposit (CDs), and commercial paper (CPs) were permitted, and interest rates for some money and bond market instruments were liberalized in the 1980s. A more comprehensive plan for interest rate deregulation, which envisaged the liberalization of most lending and long-term deposit rates, was, however, effectively revoked shortly after its introduction in late 1988 because of a sharp rise in market-determined interest rates.

The partial reforms in the domestic financial sector were accompanied by selective measures to open it up to foreign competition and to ease restrictions on international capital movements. Indirect foreign investment in the Korean stock market through special investment funds and foreign portfolio investment by Korean institutional investors was permitted on a limited scale, regulations concerning foreign direct investment were relaxed, and restrictions on the operations of foreign banks were eased. 3/ In addition, foreign life insurance companies and, on a limited scale, foreign securities firms were granted access to the domestic market.

In the early 1990s, selective measures continued while preparations for a more comprehensive reform program began. In 1991, a four-stage schedule for the complete liberalization of interest rates was announced, which was subsequently included in a comprehensive, five-year plan (blueprint) for financial sector liberalization and capital account opening. This plan was presented in 1993 and describes the core of the financial sector reform program. In addition, the Government's revised medium-term economic development plan (Five-Year Plan for the New Economy) outlines in broad terms a number of supporting reforms in the structure of the financial

1/ These include deposit money banks, such as the Korea Housing Bank, as well as nonbank financial institutions, such as the Korea Development Bank. See section 3 for a more detailed description of policy-based lending.

2/ Such requirements stipulate, for example, that banks must allocate a certain share of their loan portfolios to certain types of borrowers, such as small- and medium-size enterprises. See section 3 for a more detailed description of the system.

3/ The establishment of foreign bank branches in Korea dates back to the late 1970s. Their treatment has combined both discriminatory as well as preferential elements. 
system. I/ Subsequently, in late 1994, the five-year Foreign Exchange Reform Plan was presented, which broadens the scope of the external part of the 1993 reform plan.

The overriding objective of the reform program is to enhance the efficiency of the financial sector by reducing government intervention and facilitating greater integration into international financial markets. The program focuses on the following areas: reform of policy loans, mandatory lending requirements, and credit controls; deregulation of interest rates and financial instruments; reform of monetary policy instruments; and liberalization of foreign exchange and capital account transactions. The implementation schedule is gradual to give financial institutions time to adapt to a more competitive environment. In addition, the program includes supporting reforms to strengthen the competitiveness of financial institutions as well as bank supervision to safeguard the soundness of the financial system.

\section{Reform of the domestic financial sector}

This section focusses on the main elements of the reform agenda for the domestic financial sector: the reform of policy loans, special lending requirements, and credit controls; and the deregulation of interest rates and financial instruments (Table III.1). It also covers reforms in regulations concerning bank management, financial institutions' business activities, and the supervisory framework. It excludes issues relating to the reform of the monetary policy framework, which are discussed in chapter IV.

\section{a. Policy loans, mandatory lending ratios, and credit controls}

The Korean Government has traditionally used three instruments to influence credit allocation: policy loans, mandatory lending ratios, and credit controls. While these instruments differ significantly in their nature and rationale, their ultimate purpose is to direct the distribution of credit among different types of borrowers and projects.

1) The blueprint reflects the results of financial policy talks between the Korean and the U.S. govermments and contains a set of specific measures as well as a detailed implementation schedule. The revised five year economic development plan provides a broader and more general outline of the government's reform agenda. The main elements of both plans are summarized in tabular form in the annex to "Korea - Recent Economic Developments" $(\mathrm{SM} / 94 / 28,1 / 31 / 94)$. 
Table III.1. Korea: Domestic Financiel Sector Liberalization--Schedule and Implementation of Selected Measures 1/

\begin{tabular}{|c|c|c|c|}
\hline & $\begin{array}{l}\text { Deregulation of } \\
\text { Interest Rates }\end{array}$ & $\begin{array}{c}\text { Deregulation of Financial } \\
\text { Instruments }\end{array}$ & $\begin{array}{l}\text { Credit Control System } \\
\text { and Lending Guidelines }\end{array}$ \\
\hline $\begin{array}{l}\text { Phase } 1 \\
(1993)\end{array}$ & $\begin{array}{l}\text { Deregulation of interest } \\
\text { rates on: } \\
\text { - all loans (except policy } \\
\text { loans) (11/93); } \\
\text { - time doposits with } \\
\text { maturities of two years } \\
\text { or more (11/93); } \\
\text { - corporate and financial } \\
\text { bonds with less thm two } \\
\text { gears maturity (11/93); } \\
\text { - monetary stabilization } \\
\text { bonds (MSBs), treasury } \\
\text { and public bonds (4/93). }\end{array}$ & $\begin{array}{l}\text { Auction sales of MSBs and } \\
\text { treasury bonds }(3 / 93) \text {. }\end{array}$ & $\begin{array}{l}\text { Simplification of credit control } \\
\text { criteria and procedures for } \\
\text { large corporations }(2 / 93) \text {. } \\
\text { Increasing transparency of } \\
\text { regulations governing mandatory } \\
\text { lending to small- and medium- } \\
\text { size enterprises (SNEs) (3/93). }\end{array}$ \\
\hline $\begin{array}{l}\text { Phase } 2 \\
(1994-95)\end{array}$ & $\begin{array}{l}\text { Deregulation of interest } \\
\text { rates on loans that are } \\
\text { elisible for Box } \\
\text { rediscounting (including } \\
\text { comercial bills) }(7 / 95) \text {. }\end{array}$ & $\begin{array}{l}\text { Diversification of short-term } \\
\text { instruments (ongoing). } \\
\text { Easing of restrictions on } \\
\text { short-term finencial } \\
\text { instruments (maturities and } \\
\text { issue limits) (ongoing). }\end{array}$ & $\begin{array}{l}\text { Prior approval for investment in } \\
\text { new businesses and real estate } \\
\text { by large conglomerates to be } \\
\text { waived ( } 5 / 95 \text { ); } \\
\text { Revision of laws relating to } \\
\text { credit control system for large } \\
\text { conglomerates (Fair Irade Act, } \\
\text { Industrial Developwent Act, tax } \\
\text { laws). } \\
\text { Reduction of policy loans to } \\
\text { sers; transer of such loans to } \\
\text { government sector (ongoing). } \\
\text { Expansion of credit guarantees } \\
\text { for sers to enhamce their access } \\
\text { to credit markets (ongoing). }\end{array}$ \\
\hline $\begin{array}{l}\text { Phase } 3 \\
(1996-97)\end{array}$ & 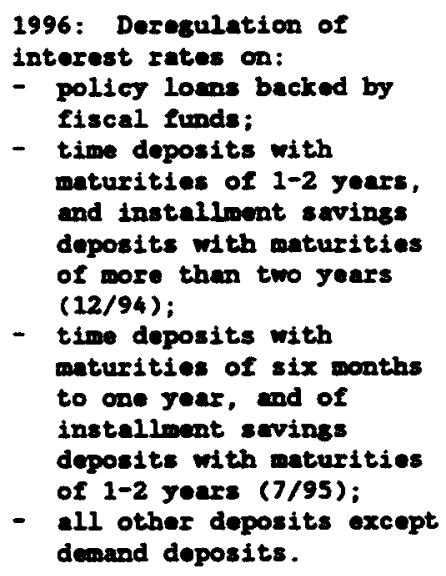 & $\begin{array}{l}\text { Authorieation of new short-term } \\
\text { products, includins money } \\
\text { market certificates and money } \\
\text { market funds. }\end{array}$ & 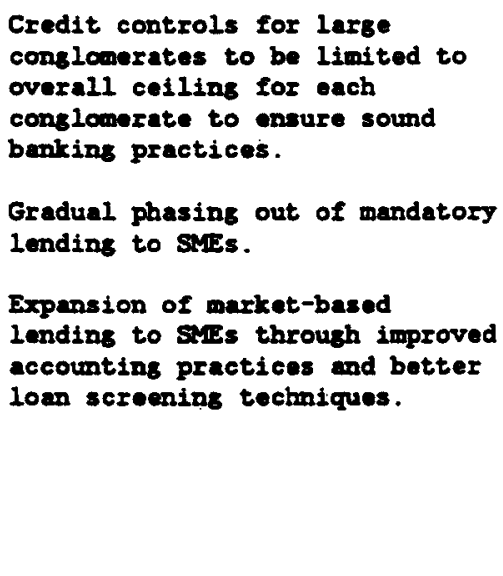 \\
\hline & $\begin{array}{l}\text { 1997: Preperation of plan } \\
\text { for phased deregulation of } \\
\text { interest rates on demand } \\
\text { deposits. }\end{array}$ & $\begin{array}{l}\text { 1997: Study on abolishins } \\
\text { restrictions on short-term } \\
\text { instruments. }\end{array}$ & \\
\hline
\end{tabular}

Source: Information provided by the Korean authorities.

1f The measures are presented accordins to the orisinal implementation schedule; dates in parentheses indicate month and year of implenentation, which, in scone cases, was ahead of schedule. 


\section{(i) Policy loans}

Policy loans can be defined as loans that are either directly (through government control of the lending institution) or indirectly (through government or central bank financial support) influenced by government policy. 1/ Based on this definition, which covers the lending activities of government-owned special banks $2 /$ and development institutions $3 /$ as well as a substantial share of commercial bank credit, policy loans accounted for 21 percent of total private sector credit in 1994, compared with 37 percent in 1980 (Table III.2). While direct financial assistance from the budget has been small, central bank refinancing has played a key role in supporting policy-based lending, with loans refinanced by the Bank of Korea (BOK) accounting for more than a quarter of the policy loans extended by deposit money banks (DMBs) during 1987-91. 4/ As a result, rediscount policy in Korea has traditionally been a tool of industrial policy and its role as a monetary control instrument has been limited.

As noted above, government intervention in the financial sector through policy-based lending was reduced substantially in the 1980s. The relative size of policy loans in relation to total private credit declined, and the differential between lending rates for general bank loans and policy loans was narrowed significantly. $5 /$ In addition, the focus of policy-based lending shifted from targeting specific industries toward functional support for activities such as exports and investment in R\&D, and support for smalland medium-size enterprises, which previously had benefitted little from the

1/ This concept is used in Cho and $\mathrm{Kim}$ (1995), and OECD (1994). There is, however, no generally agreed definition of policy loans.

2) The special banks include the Industrial Bank of Korea, which mainly lends to small-and medium-size enterprises; the Korea Housing Bank, which finances housing construction; and credit cooperatives for agriculture, forestry, and fisheries. The government is the largest shareholder in these institutions.

3/ These institutions include the Korea Development Bank, the Export Import Bank, and the Korea Long-Term Credit Bank. They are part of the nonbank financial sector. The Government is the main shareholder, with the exception of the Korea Long-Term Credit Bank, which was recently privatized. The Korea Development Bank has focussed on long-term loans for special projects, including infrastructure. The Export Import Bank has extended medium- to long-term export financing, mainly for capital goods such as industrial plants and ships. It also underwrites export insurance for domestic corporations and financial institutions. The Korea Long-Term credit bank has focussed on lending to industry.

4/ See Cho and Kim (1995).

5/ According to Cho and Kim (1995), the differential between interest rates for general bank loans and preferential loans for export financing narrowed from an average of more than 8 percentage points during 1975-80 to less than 2 percentage points during 1981-91. 
Table III.2. Korea: Policy-Based Lending, 1980-94 I/

\begin{tabular}{|c|c|c|c|c|c|c|c|}
\hline & 1980 & 1985 & 1990 & 1991 & 1992 & 1993 & 1994 \\
\hline & \multicolumn{7}{|c|}{ (In billions of won) } \\
\hline Industrial loans $2 /$ & 7,302 & 23,592 & 36,690 & 44,060 & 51,076 & 56,329 & 60,458 \\
\hline Other sectoral loans 3 & 2,178 & 6,013 & 16,810 & 20,086 & 24,092 & 28,667 & 33,030 \\
\hline \multirow[t]{2}{*}{ Total } & 9,480 & 29,605 & 53,500 & 64,146 & 75,168 & 84,996 & 93,489 \\
\hline & \multicolumn{7}{|c|}{ (In percent of private sector credit) } \\
\hline Industrial loans & 28.8 & 30.7 & 18.1 & 17.4 & 17.1 & 16.0 & 13.6 \\
\hline Other sectoral loans & 8.6 & 7.8 & 8.3 & 7.9 & 8.0 & 8.1 & 7.4 \\
\hline Total & 37.3 & 38.6 & 26.3 & 25.3 & 25.1 & 24.1 & 21.1 \\
\hline \multicolumn{8}{|l|}{ Memorandum item: } \\
\hline Borrowing from & & & & & & & \\
\hline government funds 4 & 1.2 & 5.7 & 3.0 & 2.7 & 2.6 & 2.5 & 2.3 \\
\hline
\end{tabular}

Sources: Bank of Korea, Economic Statistics Yearbook; and OECD (1994).

1) The definition of policy-based lending used in this table follows the concept adopted in OECD (1994).

2) Includes loans extended by the Industrial Bank of Korea, the Korea Development Bank, the EXIM Bank, the Long-term Credit Bank, as well as loans and discounts of the Bank of Korea.

3/ Includes loans extended by the Korea Housing Bank and Credit Cooperatives for Agriculture, Forestry, and Fisheries.

4/ Borrowing from government funds by financial institutions 1 isted in footnotes 2 and 3 , except the Bank of Korea. 
system. However, notwithstanding the reduction in the implicit subsidization of policy loans, they continued to play an important role by ensuring availability of financing in a system characterized by widespread non-price rationing due to interest rate controls.

The Government's plan for financial sector liberalization does not envisage a complete elimination of policy-based lending. It is planned, however, to further reduce its relative size in relation to total private credit, and to phase out the involvement of commercial banks and the Bank of Korea by shifting policy loans entirely to special, government-owned financial institutions with financial support provided by government funds.

The reform plan does not contain a precise schedule indicating when this shift would be completed. Nevertheless, as a first step, an aggregate ceiling on BOK rediscounts of foreign trade and commercial bills was introduced in March 1994, which ended the quasi-automatic rediscounting of such bills. 1/ Following the introduction of the ceiling system, the overall volume of BOK loans and discounts decreased from $W 16$ trillion in 1993 to W 13.5 trillion in 1994. In 1995, in order to cushion the impact on small- and medium-size enterprises (SMEs), a special fund was established to provide rediscounts for SME commercial bills. $2 /$ Furthermore, in line with the planned shift in the funding for policy-based lending, fiscal contributions to loan guarantee funds were raised from $W 150$ billion in 1993 to W 310 billion in 1994. $3 /$

\section{(ii) Mandatory lending ratios}

Mandatory lending ratios stipulate that financial institutions set aside a certain share of new loans for SMEs to ensure adequate financing for these enterprises. Formally introduced in the mid-1970s, these regulations

1/ Under the new system, the Monetary Board determines the ceiling on the aggregate rediscount volume on a quarterly basis consistent with the annual M2 target. The BOK allocates the available volume among DMBs based on their lending volume.

2/ The Industrial Bank of Korea and Kookmin Bank manage the fund. They will raise $W 1$ trillion, partly through bond issues, with the government contributing the remaining $W 250$ billion by selling small business development bonds. Firms raising funds abroad through international bond issues are expected to invest 20 percent in these bonds, or, alternatively, they will only receive permission to raise 80 percent of the intended issue volume.

3/ The Korea Development Bank, the Korea Credit Guarantee Fund, and the Korea Technology Credit Guarantee Fund were authorized to issue credit guarantees of up to $W 00$ billion, which will be backed by fiscal funds and a newly established "Infrastructure Credit Guarantee Fund." 
were expanded $1 /$ and more strictly enforced in the 1980s as disparities in access to financing between large conglomerates (which had been the main beneficiaries of extensive policy-based lending in the 1970s) and SMEs became a cause for concern. Mandatory lending ratios vary by type of financial institution. In 1992, nationwide commercial banks were required to allocate 45 percent, $2 /$ local banks 80 percent, and branches of foreign banks 25 percent of their lending to SMEs. $\underline{3} /$

Consistent with the objective of reducing government intervention in the operations of financial institutions, the financial sector reform program envisages a phasing out of mandatory lending ratios by the end of 1997, but a specific time has not been set. While the mandatory lending ratio for local banks was reduced from 80 to 70 percent in 1994, the corresponding ratios for nationwide commercial banks and branches of foreign banks have, so far, remained unchanged. 4/

\section{(iii) Credit controls}

As a complement to the system of mandatory lending ratios for SMEs, lending to large business groups has been subject to various forms of controls. Introduced in the mid-1970s to reduce companies' leverage and encourage stock market financing, such controls have been used since the mid-1980s mainly to prevent heavy concentration of credit and limit the expansion of large conglomerates through new acquisitions and real estate investment. $5 /$ In the late 1980s and early 1990s, the credit control system has focused on restricting credit to the 30 largest conglomerates through so-called basket provisions, which limit the share of lending to

1 Coverage of the system was extended from domestic commercial banks to foreign bank branches and nonbank financial institutions, and mandatory lending ratios were raised.

2/ In addition, nationwide commercial banks are required to allocate at

least 50 percent of their new loans to the manufacturing sector.

3/ Foreign bank branches that use the BOK's rediscount facility are required to set aside 35 percent of their loans for SMEs.

4/ With large enterprises resorting increasingly to capital market financing, many Korean commercial banks have begun to focus on SME lending, and, consequently, the SME lending requirements have become less constraining.

5/ While in the 1970s all business groups whose bank credit exceeded a certain amount were subject to credit controls, the coverage of the system was steadily reduced in the 1980s from 161 business groups in 1984 to the 50 largest groups in 1988. For a detailed description of the system see Nam and Kim (1993). 
these business groups in a bank's total. loan portfolio, $1 /$ and on controlling their investments in new businesses. In addition, real estate investments of the largest 50 conglomerates have been subject to controls. The system has been administered by banks under the guidance of the office of Bank Supervision and Examination. 2/

As outlined in the Government's plan for financial sector liberalization, the number of business groups that have to obtain approval for investment in real estate and new businesses has been reduced steadily in the past two years, and since May 1995 all conglomerates have been exempted. While the basket credit controls for the 30 largest conglomerates still apply, it is planned to phase out aggregate ceilings during 1996-97 and to replace them by prudential regulations limiting bank exposure to individual business groups.

\section{b. Deregulation of interest rates and financial instruments}

Interest rate controls have been extensive and affected in the past more or less all types of financial instruments. Controls on lending rates sought to keep financing costs low, $\underline{3}$ / while ceilings on deposit rates ensured a sufficient profit margin for financial institutions. The regulation of deposit rates at low levels necessitated in turn tight controls over other financial instruments so as to limit portfolio shifts away from deposits. Banks as well as nonbank financial institutions (NBFIs) have been subject to interest rate controls, but the latter have generally been allowed to offer higher deposit rates and charge higher lending rates than banks.

Selective measures during the 1980s focused on the liberalization of interest rates on money and bond market instruments such as commercial paper, call money, financial debentures, as well as guaranteed and

1 In addition to limits on total lending to the 30 largest conglomerates, there are separate limits on lending to the 5 largest business groups. In 1991, these limits were 10.81 percent and 5.8 percent, respectively, of a bank's loan portfolio. However, loans to a group's core companies, as well as loans to companies with a highly dispersed ownership have been exempted from these limits. Also, basket controls do not apply to nonbank financial institutions. See Nam and Kim (1993).

2f Each business group subject to the credit control system has a principal transactions bank which is responsible for implementing the various regulations of the system. The process of selecting a principal transactions bank is described in Nam and Kim (1993).

3. The effectiveness of these controls was, however, undermined to some extent by business practices such as compensating balances or bundling of financial services, which raised the effective cost of credit. 
unguaranteed corporate bonds. I/ In addition, new instruments such as CDs, RPs, cash management accounts, and bankers' acceptances were introduced. Nevertheless, many of these instruments, notably CDs, remained subject to restrictions on maturities, minimum denominations, and issues volumes. Even though a number of short-term bank lending rates (overdrafts, commercial bills, $2 /$ and trade bills) and long-term deposit rates (deposits with maturities exceeding three years) were liberalized in 1991 , most lending and deposit rates were still subject to controls when the financial sector reform plan was presented in 1993.

The plan envisages the deregulation of all lending and deposit rates, with the exception of interest rates on demand deposits, which will be considered in 1997. In order to limit competitive pressures during the transition to a fully liberalized system, the schedule for the liberalization of lending rates is faster than that for deposit rates, with the deregulation of long-term deposit rates preceding the liberalization of short-term rates. In addition, the plan envisions the introduction of new financial instruments such as money market certificates and funds, and a further easing of restrictions on existing ones.

In line with the plan's schedule, a substantial part of the measures have been implemented. In November 1993, all lending rates, except those for loans backed by BOK or government funds (policy loans) were deregulated. Subsequently, in July 1995, interest rates on loans that are eligible for BOK refinancing were liberalized, leaving only policy loans supported by government funds, which account for some 5 percent of total loans and discounts by DMBs and NBFIs, subject to controls.

On the deposit side, interest rates on time deposits with maturities of two years or more were deregulated in November 1993, followed in December 1994 (ahead of schedule) by the liberalization of interest rates on time deposits with maturities of one to two years, and of interest rates on installment savings deposits with maturities of over two years. With the deregulation in July 1995 (also ahead of schedule) of interest rates on time deposits with maturities of six months to one year, and on installment savings deposits with maturities of one to two years, interest rates of about 77 percent of all DMB and NBFI deposits were liberalized as of end July 1995. Liberalization of the remaining time and installment savings deposit rates scheduled for implementation by the end of 1996 .

1) Issue rates of non-guaranteed and guaranteed corporate bonds were first liberalized in 1984 and 1986, respectively. However, controls were subsequently reintroduced. The issue rates of corporate bonds were liberalized again in 1991 (for bonds with maturities exceeding two years) and in 1993 (for bonds with maturities of less than two years).

2/ Commercial bills that are eligible for BOK rediscount remained subject to controls. 
Judging from published data, the liberalization measures so far appear to have had little impact on interest rates. Lending and deposit rates have been broadly $s$, notwithstanding a rise in other market-determined rates since mid-1994 (Table III.3). I/ There is, however, some indirect evidence that rates of return on deposits may have changed after the liberalization. For example, time deposits with maturities of two years or more, whose interest rates were liberalized in 1993, have expanded rapidly since then, while time deposits with shorter maturities (one to two years) barely grew in 1993-94, picking up only in early 1995 after their interest rates were liberalized (Table III.4). There are also indications that the decontrol of deposit rates may have slowed the steady decline in the market share of commercial banks, which under controlled interest rates were at a disadvantage relative to NBFIs as the latter were allowed to offer higher returns. After declining steadily from 44 percent in 1980 to 18 percent in 1993, the share of commercial banks in total deposits of financial institutions stabilized in 1994.

With interest rates of most money market instruments liberalized prior to 1993, the financial sector reform program focuses on the gradual easing of restrictions regarding issue volumes, permissible maturities, and minimum denominations, which still apply to many short-term instruments. The Government plans to study the complete elimination of such restrictions in 1997. The measures taken so far have focused on gradually increasing issue limits for CDs, while expanding the range of permissible maturities at the short end, and lowering minimum denominations. 2/ As a result of these measures, DMBs increased their outstanding volume of CDs from $\mathrm{W} 10$ trillion in 1991 to W 24 trillion in March 1995. As for bond market instruments, yields on corporate bonds and financial debentures with less than two years maturity as well as treasury and public bonds were liberalized in 1993. The issue volume of corporate bonds continues to be controlled by the Association of Securities Dealers in order to stabilize the conditions in the primary market.

1) The apparent stickiness of nominal deposit rates may be partly due to the fact that published rates correspond to "posted" rates, while large customers tend to negotiate higher interest rates for their deposits. Similarly, published lending rates, which are presented in terms of a relatively wide range, may not adequately reflect actual lending rates. Furthermore, the stability of published deposit and lending rates may be due to nonprice competition for deposits and the continuation of practices such as compensating balances or product bundling in the lending business.

2) As of July 1995, issue limits for CDs were 150 percent of net worth for commercial banks, and the higher of 400 percent of net worth or W 25 billion for foreign banks. The shortest permissible maturity was 30 days, and the minimum denomination was $\mathrm{W} 20$ million. 
Table III.3. Korea: Developments in Selected Deposit and Lending Rates, 1990-1995

(In percent)

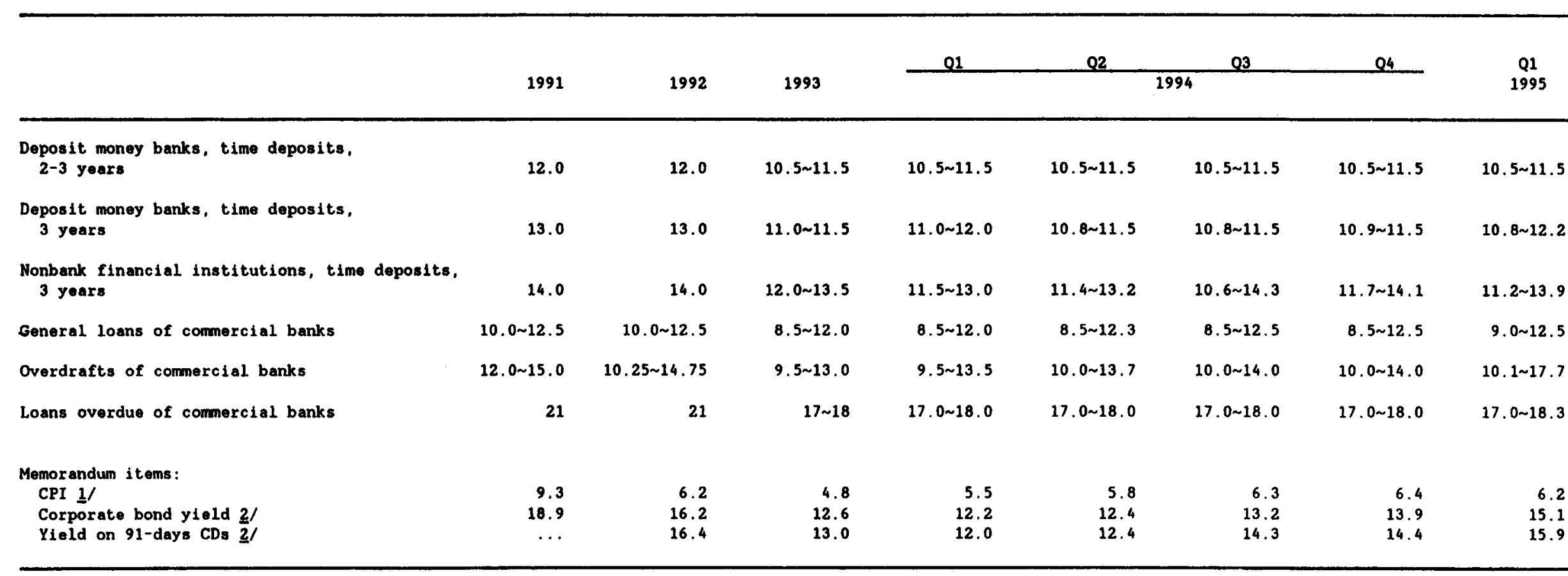

Source: Bank of Korea, Monthly Statistical Bulletin.

1/ Twelve-month average percentage change.

2/ Period average. 
Table III.4. Korea: Growth of Selected Deposits 1/

\begin{tabular}{|c|c|c|c|c|}
\hline & 1992 & 1993 & 1994 & 1995 \\
\hline & \multicolumn{4}{|c|}{ (Percentage change) } \\
\hline $\begin{array}{l}\text { Deposit money banks, } \\
\text { total deposits }\end{array}$ & $\underline{17.5}$ & $\underline{7.7}$ & $\underline{12.5}$ & $\underline{18.0}$ \\
\hline Demand deposits & 22.4 & -10.4 & 0.2 & 19.0 \\
\hline $\begin{array}{l}\text { Time \& savings } \\
\text { deposits }\end{array}$ & 15.3 & 16.1 & 16.9 & 17.7 \\
\hline Time deposits & 7.8 & 3.5 & 12.5 & 24.2 \\
\hline Less than one year & -20.0 & -9.4 & 14.8 & 10.0 \\
\hline One to two years & 14.3 & 0.4 & 0.3 & 19.6 \\
\hline More than two years & 29.1 & 19.0 & 29.7 & 37.0 \\
\hline $\begin{array}{l}\text { Installment savings } \\
\text { deposits }\end{array}$ & 19.4 & 8.1 & 16.4 & 18.6 \\
\hline Mutual installments & 8.0 & 0.5 & 19.5 & 22.2 \\
\hline Housing installments & 43.8 & 39.2 & 41.7 & 25.8 \\
\hline $\begin{array}{l}\text { Workman's property } \\
\text { formation }\end{array}$ & -9.1 & 0.6 & -10.4 & -15.8 \\
\hline Savings deposits & 13.4 & 46.1 & 33.0 & 25.7 \\
\hline $\begin{array}{l}\text { Preferential savings } \\
\text { deposits }\end{array}$ & 12.8 & 20.4 & 7.1 & 3.6 \\
\hline Company savings & 25.3 & 4.5 & 23.0 & 16.8 \\
\hline $\begin{array}{l}\text { Nonbank financial institutions, } \\
\text { total deposits }\end{array}$ & $\underline{22.6}$ & $\underline{28.6}$ & 24.9 & $\underline{19.2}$ \\
\hline
\end{tabular}

Source: Bank of Korea, Monthly Statistical Bulletin.

1) End of March of respective year relative to end of March of the previous year. 
c. Bank management, business boundaries, and the supervisory framework

In order to enhance efficiency and competitiveness, the financial sector reform program includes a number of measures to increase the autonomy of bank management and reduce restrictions on financial institutions' business activities. In addition, it envisages a strengthening of bank supervision and measures to deal with the problem of bad loans.

Even though commercial banks were privatized in the early 1980s, the Government continued to influence their management in a number of areas, such as the selection of senior bank managers, capital increases, dividend payments, and branch network expansions. Since 1993, several measures have been taken to reduce government involvement in these areas: a committee system for the nomination of commercial bank presidents was established, $1 /$ commercial banks were granted greater autonomy in the expansion of their branch network, $2 /$ and restrictions on the payment of dividends were eased. $3 /$ It is planned to gradually phase out the remaining restrictions on dividend payments in the coming years. In addition, deposit money banks were allowed to increase their capital without prior approval of the Monetary Board, and introduce new financial products without prior approval by the Office of Bank Supervision, provided the new products meet existing regulations.

Regarding financial institutions' business activities, the reform program envisions a lowering of the boundaries between DMBs and NBFIs, and a liberalization of the rules governing the activities of foreign banks and

1 The committee proposes a candidate who, if accepted by the office of Bank Supervision, is endorsed by the general meeting of stockholders. The committee consists of three ex-president of the bank, two large stockholders, two small stockholders, one representative of corporate clients, and one representative of general customers. The largest five conglomerates are excluded from representation on the nomination committee.

2/ In July 1995, nationwide banks were granted permission to open without prior approval up to 15 new branches in 1996, 23 in 1997, and 30 in 1998 provided that they meet several conditions, including a capital adequacy ratio of 8 percent.

3/ Commercial banks may currently pay up to 60 percent of their after tax net profits as dividends without prior approval by the Office of Banking Supervision if their loan loss reserves fully cover the weighted nonperforming loans and the ratio of weighted bad loans is less than 2 percent, or if they receive management performance ratings of $A$ in three consecutive years. Weighted non-performing loans include questionable loans, loan losses, and 20 percent of collateralized loans with interest payments overdue for more than three months. If loan loss reserves amount to more than 80 percent of weighted non-performing loans, banks are allowed to pay 50 percent of their net income as dividends. Banks which do not meet this requirement are allowed to pay dividends of up to 40 percent of net income. 
securities firms. The goal is to move toward a system based on three broad types of business: banking, securities, and insurance. $1 /$ So far, banks have been partly allowed to enter the securities business, $2 /$ while securities firms have been granted permission to enter the foreign exchange business on a limited scale. In addition, in order to enhance market access for foreign financial institutions, the regulations governing the operations of foreign securities firms in Korea have been eased. 3 /

In order to safeguard the soundness of the financial system as competitive pressures increase, the Government plans to strengthen the supervisory framework by integrating the supervision of the banking, securities, and insurance business. 4/ At the operational level of banking supervision, the ongoing implementation of an early warning system similar to the U.S. CAMEL system 5/ is expected to improve efficiency. Within this framework, BIS capital adequacy rules have been progressively phased in and will be applied in full beginning in 1996. BIS accounting procedures for market and interest rate risk are expected to be adopted after 1997. Introduction of a deposit insurance system for DMBs $6 /$ is scheduled for 1997 . I

Finally, in order to strengthen banks' balance sheets, a number of measures have been taken to encourage banks to write off bad loans. In 1994, the Office of Bank Supervision increased the maximum amount of bad loans which banks can write off at their own discretion to $W 1$ billion, and

1/ The three groups would be separated but business involvement across borders would be allowed through subsidiaries.

2/ Deposit money banks have been allowed to organize the issue and retail distribution of public sector bonds.

3/ Capital requirements were eased, the requirement to operate a representative office for more than two years prior to opening a branch office was dropped, the opening of more than one branch office was allowed. Foreign securities firms which have a good track record of more than two years have also been allowed to issue and trade CDs.

4/ Experiences in other countries suggest that financial sector liberalization and the ensuing higher levels of competition may lead to moral hazard and increase the systemic risk. A high burden of existing bad debt in the portfolios of financial intermediaries paired with low capitalization is likely to aggravate these problems. See Johnston (1994), and Galbis (1994).

5/ CAMEL stands for: capital adequacy, asset quality, management ability, earnings quality, and liquidity level.

6/ Currently deposit insurance is available only for NBFI deposits.

If According to a recently introduced government bill, each depositor would be insured for up to W 20 million. This would cover 97 percent of all depositors at domestic banks. The proposed insurance would protect wondenominated demand and savings deposits, and specific money trust accounts at domestic and foreign banks. Risk premia would eventually be differentiated according to business performance. 
the maximum amount of write-offs of doubtful loans from 50 percent to 90 percent of their total volume. Moreover, the permitted frequency of charge-offs during a year was increased from two to four times. The Office of Bank Supervision also changed its guidelines for providing against loan losses by requiring banks to increase loan loss reserves equivalent to the volume of expected loan losses, $1 /$ and introduced a maximum loss-risk weighted bad loan ratio of two percent of total loans which banks have to meet by 1998. 2/ Management performance reviews, which are a part of the CAMEL system, have increasingly taken into account the performance of bank managers in the identification and write-off of bad loans.

In response to these measures, commercial banks used their very high operating profit of W 4.7 trillion in 1994 (compared with $W 2.9$ trillion in 1993) to write off $W 1.7$ trillion or almost half of nonperforming loans, and to add about W 2 trillion (around twice the 1993 volume) to loan loss reserves. At the end of 1994, bad loans of commercial banks amounted to $W$ 1.9 trillion or 0.9 percent of total credit. 3 /

\section{Capital account opening and reform of the foreign exchange system}

Although in the past Korea made extensive use of foreign borrowing to finance domestic investment, most external capital transactions remained subject to tight controls and capital flows were closely monitored. In the first half of the 1980s, selective measures to liberalize capital account transactions focused on capital inflows to facilitate the financing of the current account deficit. 4/ As the current account shifted into surplus in the second half of the 1980s, several steps were taken to liberalize capital outflows. 5 However, notwithstanding these measures, and the

1 Prior to this change, banks were permitted to build up loan loss reserves equivalent to two percent of total loans.

2/ The sum of loss-risk weighted loans consists of 20 percent of substandard loans and 100 percent of doubtful and estimated loss loans.

3 In the first half of 1995, bad loans increased to $W 2.7$ trillion or 1.2 percent of total loans due to technical re-classifications and several bankruptcies.

4 Foreign investors were granted indirect access to the domestic securities market through international trust funds, and Korean firms were allowed to issue, subject to limits, convertible bonds, bonds with warrants, and depository receipts in international financial markets. At the same time, an increasing number of sectors were opened up for foreign direct investment.

5/ Korean securities companies were permitted to participate in syndicated underwriting of foreign securities, and insurance and investment trust companies were allowed to invest, subject to certain limits, in foreign securities. 
partial opening of the domestic stock market to foreign investors in 1992, 1/ restrictions on external capital account transactions have remained extensive.

The Government's reform program, which was outlined in the 1993 blueprint and elaborated and broadened in the 1994 Foreign Exchange Reform Plan, 2/ envisages a gradual reduction of controls on inward and outward capital flows (Table III.5). The strategy is to liberalize capital outflows at a faster pace and on a broader scale than capital inflows. 3 While the program entails a significant liberalization of capital flows, it does not imply the removal of all restrictions. For example, foreign investors would only gain limited access to the Korean bond market, and foreign borrowing by Korean firms would continue to be tied to imports of capital goods.

Liberalization of foreign direct investment (FDI) in Korea has focused on the gradual extension of the list of industries that are open to FDI, and on measures to facilitate the establishment and operations of FDI companies. The share of industries that are eligible for FDI has increased from 81 percent in early 1992 to 91 percent in April 1995, and is scheduled to rise further to 95 percent by early 1997. 4/ With the introduction of a "one-stop" notification system in 1994, administrative procedures were simplified and shortened. $5 /$ Furthermore, restrictions on land acquisition, foreign financing of capital goods imports, and acquisition of other companies' stocks were eased. $6 /$ Liberalization of outward direct investment (ODI) by Korean companies has concentrated on reducing the number

1) In January 1992, foreign investors were granted direct access to the domestic stock market subject to certain limits. Initially, a 10 percent limit applied to the share of total foreign investment in a company's stocks. This ceiling has since been raised twice, to 12 percent in December 1994, and to 15 percent in July 1995. The 3 percent cap on the share of a company's stocks held by a single foreign investor has so far remained unchanged.

2) In addition, in mid 1994, the Government presented a plan for the improvement of the environment for foreign direct investment

3/ This strategy is based on the presumption that given the large interest differential in favor of Korean assets, the opening of the capital account will lead to substantial net inflows of capital.

4/ Figures are based on the 1994 Reform Plan for the Improvement in the Foreign Investment Environment.

5/ Explicit approval is still required in exceptional cases.

6/ In addition, the tax treatment of FDI companies has been improved and measures to ameliorate labor management relations are planned. 
1. Outflows

Direct investment

$\$ 10$ million subject to
approval; investment in
14 Industries restricted

\section{Portfollo investmont}

Institutional. investors

F1 rms

\section{Individuals}

Overseas deposits for asset management

Institutional investors

Firms

Individuals

Credit to nonresidents for asset management

Institutional investors

\section{Firms}

Individuals

\section{Real estate purchases}

No limits, except for ponsion funds and

investonent and finance companies

W 300 million 11mit

W 100 million limit

$\begin{array}{ll}\text { Investments exceeding } & \begin{array}{l}\text { Approval system } \\ \text { abolished; }\end{array} \\ \text { \$30 million subject } & \text { investment in all } \\ \text { to opproval; number } & \text { nonfinancial } \\ \text { of restricted } & \begin{array}{l}\text { industries } \\ \text { permitted }\end{array} \\ \text { industries reduced } & \end{array}$

W 1 billion $11 \mathrm{mit}$

Limits abolished

W 500 million limit

Limits abolished

$\$ 100$ million limit Limits abolished

$\$ 1$ million limit

Limits raised

Limits abolished

$\$ 30,000$ limit

Limits raised

Limits raised

Prohibited
Prohibited
Prohiblted
Limited to certaln types
of investors and subject
to ceilings

$\$ 10$ million limit

Limits raised

$\$ 300,000$ 11mit

Limits ralsod

Prohibited

Prohibited

Expansion of list of

eligible investors:

to cellings

Expansion of list
of ellg1ble
investors;

ceilings raised
Limits raised

Limits raised

Permitted subject

to limits

Liberalized for

Institutional

investors and

firms; for

individuals

subject to

CInternational Monetary Fund. Not for Redistribution 
Table III.5 (Continued). Korea: Schedule of Planned Capital Account Liberalization Measures $\underline{1}$

\begin{tabular}{|c|c|c|c|c|}
\hline & Unt11 1994 & 1995 & $1996-97$ & 1998-99 \\
\hline $\begin{array}{l}\text { Issuance of securities in domestic } \\
\text { markets by nonresidents }\end{array}$ & Prohibited & $\begin{array}{l}\text { Issuance of equities } \\
\text { and equity-linked } \\
\text { bonds liberalized; } \\
\text { lasuance of won- } \\
\text { denominated bonds by } \\
\text { International } \\
\text { organizations } \\
\text { permitted }\end{array}$ & $\begin{array}{l}\text { Issuance of won- } \\
\text { denominated bonds } \\
\text { liberallzed }\end{array}$ & $\begin{array}{l}\text { Issuance of } \\
\text { forelgn-currency- } \\
\text { denominated bonds } \\
\text { liberalized }\end{array}$ \\
\hline
\end{tabular}

2. Inflows

Stock market investment by nonresidents

Bond market investment by nonresidents

Issuance of securities abroad

Commercial loans to finance capital goods imports $\underline{2}$ /

\section{Overseas financing of overseas} operation

\section{2 percent colling on foreign investment per company}

\section{Limited to public sector bonds with interest}

rates comparable to international interest rates and convertible as SME bonds

Permitted to subject to overall annual cellings

Prohlbited $3 /$

Restricted depending on use of funds

\section{5 percent ceiling on Ceiling raised foreign Investment \\ per company \\ Indirect Investment through bond funds \\ allowed \\ Investment in nonguaranteed, \\ long-term SME \\ bonds allowed \\ Ceiling raised or abolished \\ Limited investment

$$
\text { in all }
$$ \\ nonguaranteed \\ long-term \\ corporate bonds \\ allowed}

Annual cellings

raised

Permitted for certain types of firms

Restrictions eased
Ceilings abollshed for equity-linked bonds

Permitted for all firms subject to coilings and SMEs without collings

\section{Liberalized}

\section{Liberalized for}

All cellings

abolished

all firms 
Table III.5 (Concluded). Korea: Schedule of Planned Capital Account Liberalization Measures 1/

Unt11 1994

1995

1996-97

1998-99

Trade credit

Deforred Import payant

Export dompaymonts $\underline{4}$

Intermediary trade finencins
Importe for re-export: 150 days

Importe for domestic use: 60 days

Subject to ldmits (5 percent of previous year's export velue) Limited to 80 percent of
export value

Advance recelpt of export payments before import payments not allowed
Imports for reexport: 180 days

Imports for domestic use: 90 days (Stess : 120 days)

Limit raised to 10 percent of previous year's export value (SABs:

liboralized)

Unchanged

Advance recelpt period: 30 days period extended

Advance receipt period extended

Limit raised to 30 percent of previous year's export value

Unchanged

Limit abolished

Ther

Source: Ministry of Finance, Forelgn Exchange Reform Plan, December 1994.

1/ Based on the Foreign Bxchange Reform Plan presented in December 1994. Reform measures relating to forelgn direct investment in Korea are not covered by this plen.

2) Commerciel loans are defined as overseas borrowing which exceed $\$ 1$ million and maturity of over three years.

3 With the exception of publio enterprises, and, subject to restrictions, forelgn-invested companies.

If For ships and plants. 
of restricted industries and simplifying approval procedures. 1 It is planned to allow ODI in all nonfinancial sectors and to abolish the approval system by the end of 1997.

Regarding portfolio capital, the program envisages a more complete and faster liberalization of outflows than inflows. The remaining limits on outward portfolio investment by institutional investors have been abolished, and those for firms and individuals will be eliminated in 1996-97. By contrast, while further increases in the limit on foreign investment in the domestic stock market (currently 15 percent) are planned, it is not certain that they will be completely eliminated by 1999. 2/ Similarly, foreign investment in the domestic bond market, at present only permitted for certain types of public bonds and bonds issued by SMEs, $3 /$ is set to be expanded to other types of bonds but would remain subject to limits. 4/

While Korean firms have been permitted to issue foreign-currency denominated bonds abroad since the mid 1980s, albeit subject to annual limits on the issue volume, bond issues by foreign residents in Korea were first allowed in May 1995 when international organizations were granted permission to issue won-denominated bonds. The Government plans to widen the range of issuers in the coming years and to permit by 1999 also the issuance of foreign-currency denominated bonds in Korea. $5 /$ At the same time, limits on overseas issues of foreign-currency denominated bonds by Korean residents will gradually be raised and eventually abolished.

In addition to direct and portfolio investment, the capital account liberalization program covers the following forms of foreign investment:

1 As of July 1995, outward direct investment by Korean companies exceeding $\$ 30$ million was subject to approval, investments of \$0.3-30 million were subject to notification.

2/ The 3 percent limit of individual foreign ownership has so far been retained and the reform plan does not specify any changes in the limit.

3/ Foreign investment in public bonds is limited to the primary market for bonds whose interest rates are close to international rates. Foreign investment in bonds issued by SMEs is restricted to convertible, nonguaranteed bonds and subject to a 30 percent limit on total foreign investment per issue and a 5 percent limit on individual investors.

4/ Foreign investment would remain restricted to non-guaranteed bonds.

5/ Foreign as well as domestic residents would be allowed to issue such bonds. 
overseas deposits for asset management, 1 which so far have not been allowed; lending to foreign residents, 2/ which has been restricted to banks and ODI-related operations; and real estate investment, which has only been allowed for institutional investors, general trading companies, and in connection with ODI. It is planned to gradually liberalize these transactions by raising investment limits and broadening the range of investors. However, while restrictions on investments by institutional investors and firms are expected to be eliminated by 1999, 3 / limits would continue to apply to individual investors.

Direct foreign borrowing by Korean firms through commercial loans 4 / has so far been virtually prohibited, $5 /$ with access to such loans restricted to selected public enterprises and, on a limited basis, foreigninvested companies. $6 /$ It is envisaged to gradually expand the range of borrowers, initially mainly to SMEs, and the types of projects for which access to commercial loans will be permitted. By 1999, all commercial loans are expected to be liberalized, but borrowing would remain confined to capital goods imports or refinancing of foreign debt. At the same time, restrictions on guarantees and collateral offered by Korean residents to nonresidents would gradually be eased. I/ Restrictions on foreign borrowing for overseas investment are set to be abolished in 1996 .

1 Overseas holdings of foreign currency have so far been restricted to foreign business activities. Prior to 1993, only general trading companies were permitted to hold foreign currency overseas. In 1993, the permission was extended to other companies within certain limits, provided their external transactions exceed a certain minimum amount. Both, the limits and the eligibility criteria have since been eased but not abolished.

Individuals are allowed to hold, within relatively narrow limits, foreign claims overseas without remitting them to Korea.

2/ Defined as lending for the purpose of asset management.

3/ Lending for the purpose of asset management would remain subject to ceilings even for institutional investors.

4/ The category "commercial loans" covers foreign borrowing in excess of $\$ 1$ million and with a maturity of more than 3 years for the purpose of capital goods imports or the repayment of other foreign debt.

5/ Korean firms have had access to foreign currency loans through domestic financial institutions, which have been allowed to borrow abroad and onlend these funds. Such borrowing has, however, been subject to government controls.

6/ Earlier this year, foreign-invested companies in the manufacturing sector were allowed to borrow directly abroad. The limits on such borrowing are higher for high-tech related activities than for other activities.

If Currently only foreign exchange banks are free to offer or accept guarantees and collateral. Companies (financial as well as nonfinancial) and private individuals need approval. It is planned to gradually reduce this requirement within certain limits. 
While trade-related capital account transactions involving outflows, such as export financing, are relatively free of restrictions, transactions involving inflows, such as deferred import payments and advance payments on exports, have remained subject to a number of controls. According to the Foreign Exchange Reform Plan, these controls will be eased substantially but not eliminated completely. In particular, receipt of advance payments on exports would continue to be subject to an overall ceiling, $1 /$ and deferred payment of imports would remain subject to limitations on the payment period.

While Korea's foreign exchange system has been free of restrictions on current transactions since $1988,2 /$ the enforcement of existing controls on capital flows has required detailed regulations concerning foreign exchange transactions, such as documentation requirements, a foreign exchange concentration system, and restrictions on the operations of foreign exchange banks. The financial sector reform program envisages a significant easing of these regulations in order to enhance the efficiency of the foreign exchange system.

Substantial progress has been made in easing exchange regulations. The foreign exchange concentration system, which obliged residents to sell or deposit the foreign exchange they received at specified financial institutions, was de facto abolished in 1994. The remaining requirement to register with a foreign exchange bank foreign currency holdings that exceed a certain amount is expected to be abolished in 1995. Documentation requirements have been eased in recent years by granting waivers for transactions below certain limits and gradually raising these limits. The Government plans to eliminate the remaining documentation requirements in 1996, but the "real demand" principle for foreign exchange transactions will be retained. $3 /$

Operations of foreign exchange banks are constrained by ceilings on their net foreign asset and liabilities positions. These ceilings apply to the combined spot and forward positions in relation to a bank's net worth. 4/ They have been raised several times in recent years and it is

1/ This ceiling is defined as a percentage of the previous year's export value.

2 Korea accepted the obligations of Article VIII, sections 2, 3, and 4 in November 1988 .

3/ This implies that all foreign exchange transactions must be related to a current account transaction or a permitted capital account transaction, even though documentation verifying the underlying transaction is no longer required.

4/ Until 1993, the position limits were defined in relation to a bank's average balance of foreign exchange bought in the preceding month. During a two year transition period (1993-95) banks were permitted to chose between the average balance and the net worth concept. 
planned to increase them further. The Foreign Exchange Reform Plan leaves, however, open whether they will eventually be abolished.

\section{Summary}

As a result of extensive government regulation and intervention, the development of the financial sector in Korea has lagged behind. After a decade of partial reforms, financial sector liberalization and capital account opening became a top priority in the early 1990s, and in 1993 a comprehensive reform program was presented. The key objective is to deregulate the financial sector in order to enhance efficiency while avoiding financial instability. This is to be achieved through a gradual implementation schedule as well as supporting measures to strengthen the competitiveness of financial institutions and the supervisory framework.

The reform program entails a significant reduction in the degree and scope of goverment intervention in the financial sector, even though it does not imply complete liberalization in all areas. Implementation of the planned measures has so far been on, and in several cases ahead of, schedule. In particular, most lending rates and more than three quarters of the deposit rates have been liberalized, and a number of measures have been taken to reduce government intervention in the allocation of credit through policy loans, mandatory lending ratios, and credit controls. In addition, reforms to enhance the autonomy of bank management, ease restrictions on financial institutions' business activities, and improve bank supervision have been introduced. Substantial progress has also been made in reducing bad loans.

Consistent with the planned sequencing of the reforms, the Iiberalization of the donestic financial sector has proceeded at a faster pace than the opening of the external capital account. The reform program envisages a significant reduction of capital controls but not the complete elimination of all restrictions. The liberalization of capital outflows in such areas as portfolio investment, foreign lending, and trade credit is more advanced than the liberalization of inflows, and, according to the reform plan, would stay ahead, even though further liberalization of inflows is planned. Substantial progress has also been made in easing foreign exchange regulations such as documentation and concentration requirements, which are expected to enhance the efficiency of the foreign exchange system. 


\section{References}

Bank of Korea (1994), Financial Liberalization and Internationalization in Korea, Seoul.

Cho, Yoon-Je, and Joon-Kyung Kim (1995), "Credit Policies and the Industrialization of Korea," World Bank Discussion Paper, No. 286.

Cho, Yoon-Je, and T. Hellmann (1994), "The Government's Role in Japanese and Korean Credit Markets: A New Institutional Economic Perspective," Seoul Journal of Economics, Vol. 7, pp. 383-415.

Frankel, J. A. (1994), Recent Changes in the Financial Systems of Asian and Pacific Countries, mimeo.

(1993), "Foreign Exchange Policy, Monetary Policy and Capital Market Liberalization in Korea," in Korean - U.S. Financial Issues, Academic Studies Series, Joint Korea - U.S. Academic Symposium, Vol. 3, New York.

Galbis, V. (1994), "Sequencing of Financial Reforms: A Review," IMF Working Paper, WP/94/101.

International Monetary Fund, "Korea--Market Liberalization and Macroeconomic Policies," SM/90/188, 9/26/90.

Johnston, R. B. (1994), "The Speed of Financial Sector Reform: Risks and Strategies," IMF Paper on Policy Analysis and Assessment, PPAA/94/26.

Jwa, Sung-Hee (ed.) (1993), Monetary and Financial Policy Reforms: European Experiences and Alternatives for Korea, Papers and Discussions from a Joint KDI/FES Conference, Seoul.

Ministry of Finance (1993), Financial Sector Reform Plan of the New Five Year Economic Plan, Seoul.

\section{(1993), Third Stage Plan for Financial Liberalization and Market} Opening, Seoul.

(1994), Reform Plans for Improvements in the Foreim Investment Environment, Seoul.

(1994), Foreign Exchange Reform Plan, Seoul.

Nam, Sang-Woo (1992), "Korea's Financial Reform Since the Early 1980s," Korea Development Institute, Working Paper.

Nam, Sang-Woo, and Dong-Won Kim (1993), "The Principal Transactions Bank System in Korea and Its Comparison with the Japanese Main Bank System," Korea Development Institute, Working Paper No. 9312. 
OECD (1994), Country Study: Korea, Paris.

Park, Yung Chul (1994), "Korea: Development and Structural Change of the Financial System," in H. T. Patrick and Yung Chul Park (eds.), The Financial Development of Japan. Korea, and Taiwan. Growth. Repression. and Liberalization, New York.

Shin, Yoonsoo (1995), "The Policy Direction for Korea's Liberalization of Foreign Exchange and Capital Transactions," Ministry of Finance and Economy and Korea Development Institute, Economic Bulletin, pp. 20-27.

Tseng, W., and R. Corker (1991), "Financial Liberalization, Money Demand, and Monetary Policy in Asian Countries," IMF Occasional Paper No. 84. 


\section{Saving Behavior--Determinants and Prospects 1}

\section{Introduction}

A striking feature of Korea's experience has been the remarkable rise in its saving rate over the last 25 years (Table IV.1 and Chart IV.1). As a result, Korea now has one of the highest saving rates in the world. This chapter addresses the question of what accounts for the marked rise in the saving rate, and examines whether it is likely to be sustained, given the ongoing structural changes in the financial and external sector and changing demographic trends.

Several studies have examined saving behavior in Korea, most of them in the context of multi-country analyses using pooled data on national saving. 2/ Such an approach, however, runs the risk of overlooking particular characteristics of countries in the attempt to identify a minimum set of common influences. This study examines the determinants of private saving in Korea, and attempts to establish whether there has been a structural break in private saving behavior as a result of the gradual liberalization in the financial system initiated in the early 1980 s. The prospects for private saving in Korea are then assessed in light of the evidence on the impact of past liberalization measures.

The study suggests that demographic and income factors account for most of the rise in the private saving rate over the last 25 years. It also suggests that the moderate decline in the private saving rate since 1988 was mainly accounted for by the effects of the financial liberalization initiated in the $1980 \mathrm{~s}$. However, it does not find sufficient evidence to support the hypothesis that financial liberalization caused a structural break in private saving behavior. Finally, it argues that the private saving rate is not likely to decline any further over the medium term.

The remainder of this chapter is organized as follows. Section 2 reviews the historical trends in total and sectoral saving rates (household, corporate, and government) in Korea and analyzes their interactions.

Section 3 introduces the theoretical framework of the paper and outlines the issues to be addressed. Section 4 presents the empirical specification of the model and the estimation results. Section 5 discusses the results of a simulation exercise which illustrates the medium-term prospects for the private saving rate. Finally, the last section contains a summary and concluding remarks.

1/ Prepared by Dimitri Tzanninis.

2) See, for example, Collins (1994), Nam (1989) and (1990), Lahiri (1989), Giovannini (1985), and Yusuf and Peters (1984). Their results underscored the importance of anticipated and unanticipated income, demographic factors, the real interest rate, and inflation. See also Chandavarkar (1993) for a survey of the literature on saving behavior in Asian-Pacific countries. 
Table IV.1. Korea: Selected Economic Indicators, 1960-94 (In percent of GDP: unless otherwise indicated) 1

$$
1960-69 \quad 1970-79 \quad 1980-89 \quad 1990-94
$$

$\begin{array}{lcccc}\text { Real GDP growth (in percent) } & 7.6 & 8.4 & 8.1 & 7.0 \\ \text { Gross national saving } & 14.5 & 22.4 & 30.1 & 35.3 \\ \text { Gross private saving 2/ } & 7.3 & 18.3 & 23.8 & 27.0 \\ \text { Gross government saving } 3 / & 7.2 & 4.2 & 6.3 & 8.3 \\ \text { Gross domestic investment } & 17.2 & 28.1 & 30.1 & 36.7 \\ \text { Current account balance } & -2.0 & -5.0 & -0.1 & -1.3 \\ \text { Budget balance } 4 \text { / } & -0.5 & -1.6 & -1.0 & -0.4\end{array}$

Sources: Data provided by the Korean authorities; and staff estimates and calculations.

1/ Figures are averages over the specified period.

2/ Including public enterprises.

3/ Current revenue less current expenditure of general government, on a national accounts basis.

4/ Consolidated central government. 


\section{Trends in savino rates}

The gross national saving rate rose sharply from 1970 to 1988 , when it peaked, and subsequently stabilized at about 35 percent of GDP, almost double the level of 1970 (Chart IV.1). I/ The rise in the saving rate was punctuated by large cyclical swings associated with both domestic and external shocks, most prominently the oil shocks of 1973-74 and 1979-80, and their resulting impact on the terms of trade and inflation. Fluctuations in national saving have been largely reflected in the current account position, as domestic investment has been less volatile.

Chart IV.2 shows the contributions to national saving of the private (households and corporate enterprises) and public sectors (general government). Private saving accounts for most of national saving, and has been the driving force behind both the trend rise and the short-run fluctuations in the national saving rate. The government saving rate shows a slight upward trend, accounting, on average, for about one third of national saving. While the private saving rate has declined somewhat since 1988, the rise in the government saving rate has helped to maintain a broadly unchanged national saving rate. $2 /$

The decomposition of private saving indicates that household saving accounts for most of private saving and is also the principal determinant of both the long-run trend and short-run fluctuations in the private saving rate (Chart IV.2). 3/ Household and private saving rates have shown considerable volatility--mostly associated with the two oil shocks-declining in the mid-1970s and early 1980s, and recovering again during the strong expansions of 1976-78 and 1986-88. The latter recovery of private saving was initially due to strong profits in the business sector, followed by a rise in household saving in the wake of large real wage increases,

1) The difference between gross and net saving rates increased somewhat over the same period; nonetheless, the underlying trends have been very similar. The growing divergence between gross and net saving rates in recent years reflects accelerated depreciation related to increased investment in shorter-lived, new-technology capital equipment, such as computers.

$2 /$ The distinction between private and government saving and the seemingly weak response of private saving to changes in government saving implicitly raise the question of the validity of the Ricardian equivalence hypothesis. This question is addressed in the following sections.

3/ This study focuses on private, rather than household, saving for a number of reasons. First, national accounts data on private saving are generally more reliable. Second, given that many quasi-corporate enterprises in Korea are small family businesses, their classification as either households or corporate entities can be, at times, arbitrary. Finally, it has been suggested that households tend to offset changes in saving by corporations. As a result, changes in private rather than household saving are better indicators of fluctuations in national saving. 
- $64 a-$

CHART .V.1

KOREA

SAVING, INVESTMENT, AND THE CURRENT ACCOUNT, 1970-94

(In percent of GDP)
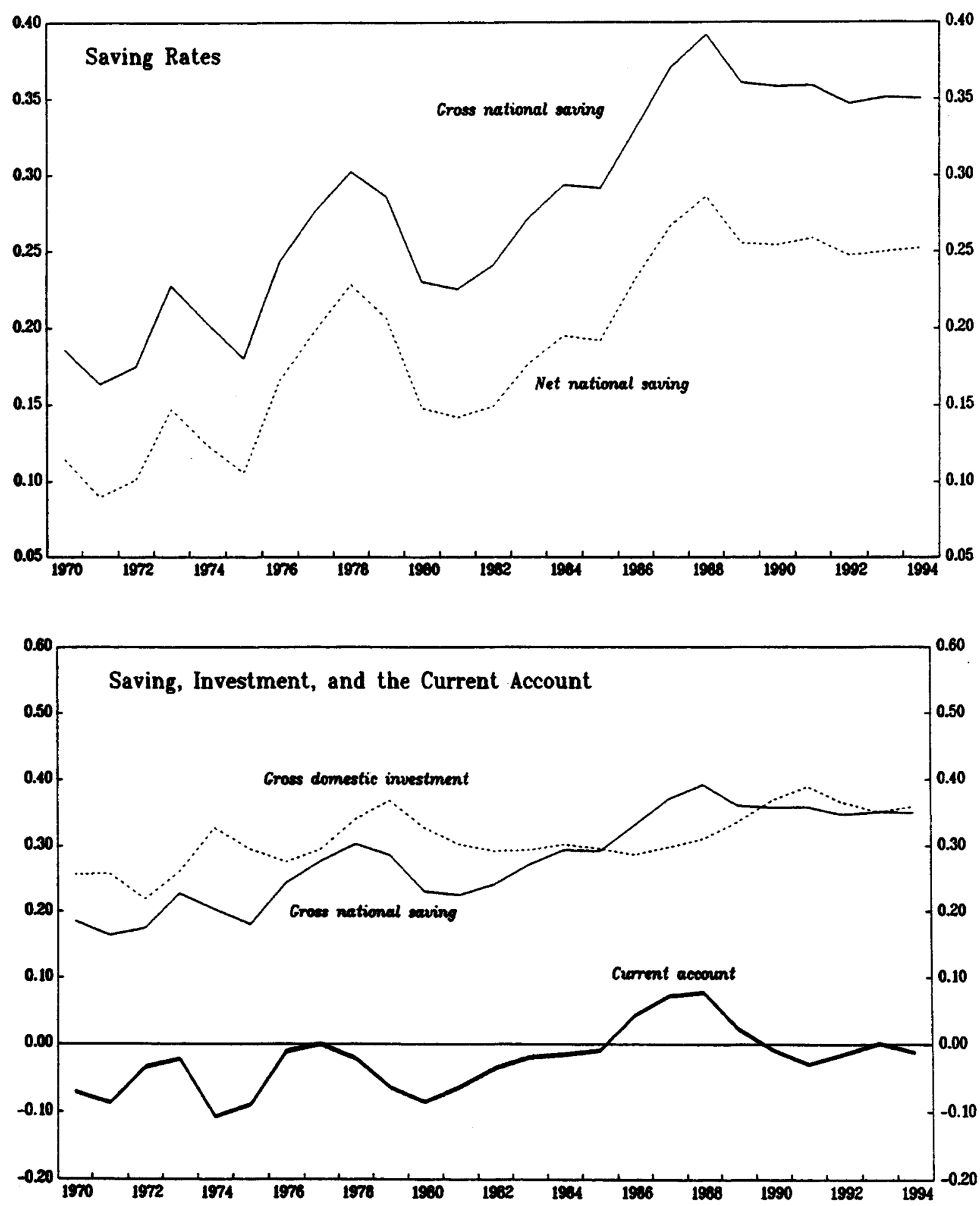

Sources: Dala provided by the Karean authorities; and staff calculations. 
CHART IV.2

KOREA

SAVING RATES, 1970-94
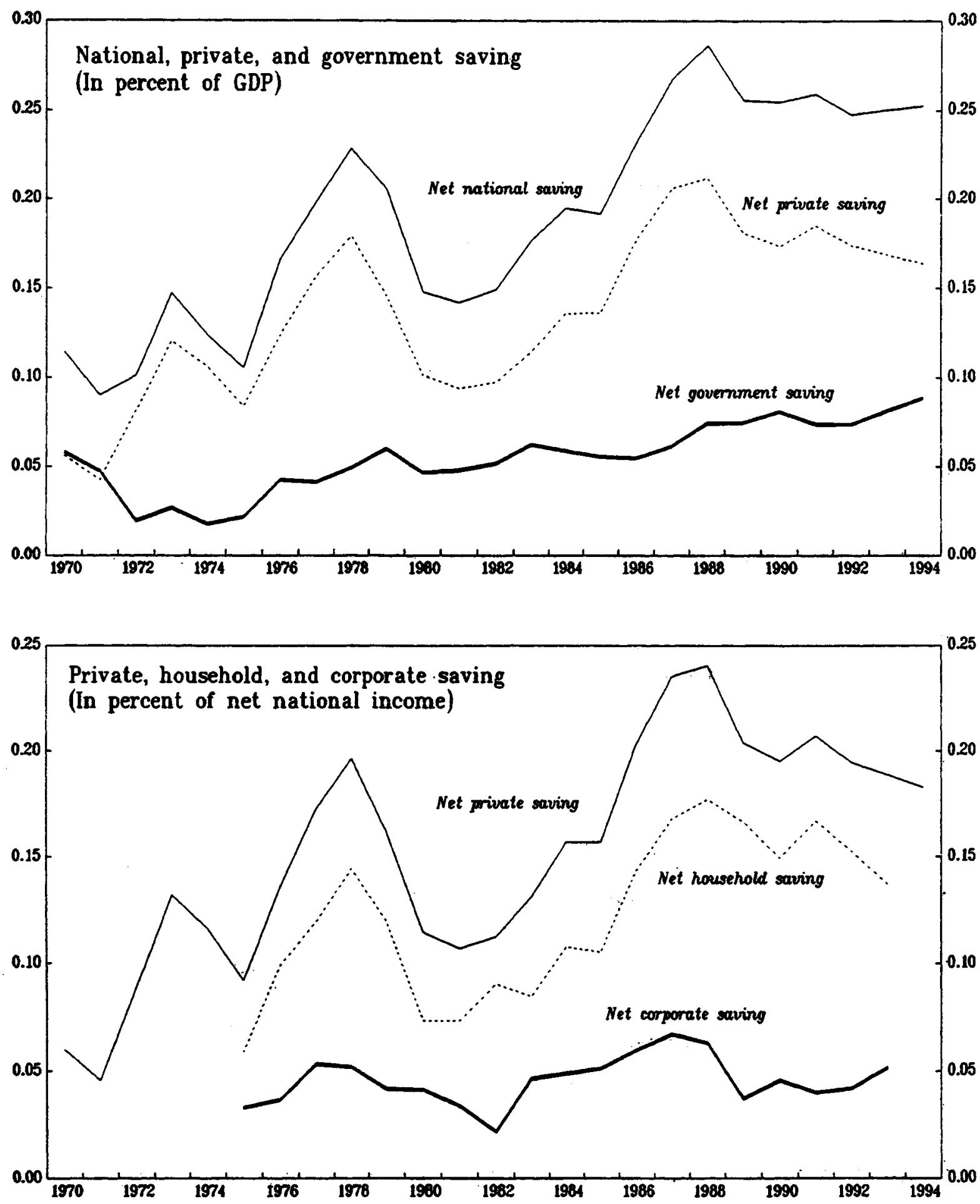

Sources: Bank of Korea, National Accounts; and staff calculations.

CInternational Monetary Fund. Not for Redistribution 
which benefitted the economically active segments of the population with a relatively high saving rate. I/ As a result, saving rates rose well above trend.

Household and private saving rates declined in the downturn of 1989 and did not recover in the subsequent expansion, even though growth rates of per capita income were comparable to rates prevailing in the past. This apparent change in private saving behavior occurred during a period when the process of financial liberalization gathered momentum and private credit expansion was facilitated, raising the question whether financial liberalization led to a decline in the private saving rate. As regards corporate saving, it was also affected during the two cyclical downturns in the 1980s, mirroring the reduction in profits and retained earnings.

\section{Theoretical framework}

\section{a. A basic theory of aggregate saving}

The most popular framework for examining individual saving behavior has been the life-cycle model. According to this model, individuals save principally to smooth consumption over their lifetime, subject to an intertemporal wealth constraint. 2/ A basic implication of this model is that individuals are likely to dissave when they are young, save during their prime working years, and dissave again when they retire. Several extensions to the basic model have incorporated bequest motives (to analyze the impact of government saving on private saving behavior), and imperfect capital markets characterized by the presence of liquidity constraints. $3 /$ The model in its extended form suggests that aggregate individual saving is likely to depend on the following variables: income (growth rate and level), wealth (stock of net wealth and accrued capital gains), demographic factors (age composition, retirement age and life expectancy of the population), the real return on saving (expected real interest rates and perhaps inflation), and government saving.

1/ The boom in the real estate market during 1986-88 may also have contributed to higher household saving rates during that period. Limited availability of consumer credit and housing finance, combined with large increases in housing prices probably helped to boost aggregate household saving during that period, notwithstanding opposing effects steming from capital gains of house owners. According to Jappelli and Pagano (1992), the loan-to-value ratio (the amount of loan granted over the value of the housing purchase) ranges from 20 to 40 percent in Korea, necessitating considerable saving for housing finance.

2/ The model was developed by Ando and Modigliani (1963).

3/ By liquidity constraints is meant the inability of economic agents to borrow or lend freely in capital markets to smooth consumption intertemporally. As a result, current consumption becomes more sensitive to current rather than expected lifetime income. 
These variables affect aggregate saving through the following mechanisms. Growth in per capita income-raises aggregate saving and the aggregate saving rate, although it does not, per se, affect the individual average propensity to save. This effect works through the aggregation process, where by increasing the incomes of the workers (who are savers), relative to those who do not earn labor income (the young and retired, who are dissavers), the aggregate saving rate moves closer to the saving rate of the workers. Improvements in net wealth and accrued capital gains may depress saving by raising the present discounted value of lifetime wealth, thus diminishing the need for saving out of current income. The age composition of the population determines the proportion of dependents (dissavers) to working-age individuals (savers). The higher is the proportion of dependents in the population, the lower is aggregate saving.

The impact of changes in (expected) real interest rates on saving behavior is ambiguous, as theory predicts two potentially offsetting effects: a negative income effect and a positive substitution effect. Similarly, the effect of inflation is also ambiguous, as it could potentially influence saving in several ways. On the one hand, the erosion of the real value of wealth and the precautionary motive work to raise saving. On the other hand, higher uncertainty about the real rate of return on saving could reduce saving. Government saving and dissaving--defined as the excess of current revenue over current expenditure--could also affect private saving. Under certain assumptions, a decline in government saving through a tax cut could be fully offset by an increase in private saving in anticipation of future tax obligations, leaving the overall national saving unchanged. $1 /$

\section{b. Further analytical issues}

The theoretical framework of the present study is primarily based on the life-cycle hypothesis of consumption smoothing, which provides a reasonable theory of long-run saving behavior. However, it also attempts to integrate related theories to allow for various other saving motives in an intertemporal framework. Such an approach is justified by the empirical evidence which suggests that no single theory seems to fully describe short-

1) This is the essence of the Ricardian equivalence hypothesis (Barro, 1974), which postulates that individuals will fully offset any increase/decrease in government saving to counter through intergenerational transfers any future tax obligations to their offspring. The hypothesis relies on bequest motives, farsighted individuals, and perfect capital markets. 
and long-run private saving behavior. 1/ The study departs from the pure life-cycle model by allowing for imperfect capital markets and thus a potentially stronger correlation of consumption with current (anticipated) income due to pervasive liquidity constraints. Furthermore, the study incorporates the presence of bequest motives and thus a test of the Ricardian equivalence hypothesis.

Preliminary regressions were run which included anticipated and unanticipated income (the former derived from regressing current income on its two lags and a time trend, and the latter being the residuals of that regression). The results (not reported) indicated that unanticipated income did not bring any new information into the regression beyond the information already conveyed in the growth rate of income. As for the influence of anticipated income, it was positive and statistically significant, indicating some responsiveness of saving to anticipated current income. 2/

Rising per capita real income is expected to increase saving rates, especially in economies where a fraction of the population face liquidity constraints or are involved in subsistence consumption. The latter could apply to Korea until the early 1970s, when private saving rates were very low, reflecting per capita real incomes at only a small fraction of the ones prevailing in the United States. 3/ As per capita real incomes rise over time, individuals move away from subsistence consumption and start saving. As rising real incomes contribute to rising marginal propensity to save and increasing wealth, the negative feedback from wealth effects begins to gradually offset the positive effect of rising incomes on saving rates.

1 Empirical failures of random-walk type models of consumption have often been attributed to the presence of liquidity constraints, which prevent a fraction of the population from fully smoothing their consumption over time, thus rendering consumption and saving responsive to current total income, not just the unanticipated component. For similar reasons, the validity of the life-cycle model has been questioned for economies where capital markets are imperfect. For such economies, a variant of the lifecycle model which incorporates a simple Keynesian feature to account for the dependence of consumption on current (anticipated) income would seem more appropriate.

2/ However, the "smoothing" of the income variable introduced the problem of multicollinearity. Consequently, current total income was used in subsequent regressions.

3/ One could, of course, argue that these low saving rates may just be a data problem, as a portion of private saving took, in the absence of better saving outlets, the form of real physical assets which count as consumption in the national accounts. Moreover, low-income economies are associated with a relatively large underground economy. Since consumption expenditure is better captured than income, this could also understate saving. Nevertheless, the very low per capita levels of real income in Korea during the 1960s and part of the 1970s suggest that subsistence consumption was prevalent for a large part of its population, especially in rural areas. 
Another negative effect comes from the fact that the accumulated wealth increases the value of one's collateral thereby providing greater access to credit markets and reducing further the need for saving. Indeed, such a "hump-shaped" effect of income on saving has been observed in many countries through their various stages of development.

This study also attempts to capture the effects of the partial liberalization of financial markets and capital movements since the early 1980s. If Since the reforms have been gradual and interspersed with occasional setbacks, the effects of the measures on private saving may be hard to uncover in a regression analysis. Nevertheless, it seems essential to attempt to capture these effects in order to shed light on the question of how the process of financial liberalization currently under way is likely to affect private (and national) saving over the medium term.

Theory suggests that the impact of financial liberalization on private saving behavior is ambiguous. On the one hand, reforms of the financial system could help raise saving by expanding the range of available assets, and also potentially raising real interest rates with the removal of controls on nominal rates. However, if the deregulation of the domestic financial sector is accompanied by an easing of capital controls, and domestic interest rates are, as currently in Korea, higher than international interest rates, an increase in the availability of foreign saving is likely to exert downward pressure on domestic interest rates and aggregate domestic saving. On the other hand, financial liberalization could result in greater access to credit by previously liquidity-constrained individuals, thus weakening certain saving motives, such as saving for purchases of consumer durables. Furthermore, the easing of liquidity constraints could reduce the sensitivity of saving to current income, and increase its sensitivity to real interest rate changes, since the presence of liquidity constraints implies a relatively small interest rate elasticity of saving. Both implications can be tested empirically.

While financial liberalization affects saving though a variety of variables, the proxy for financial liberalization in Korea adopted here is the outstanding stock of credit to the private sector, expressed as a ratio to GDP. This variable could capture, in particular, the increased availability of credit to the private sector and the resulting easing of

1/ The liberalization measures included the gradual easing of several interest rate controls, expansion of the permissible range of activities to financial institutions, opening of capital markets to small savers, greater access by households and businesses to credit, and some relaxation of controls on the international movement of capital. 
liquidity constraints for individuals and businesses. 1/ An advantage of using this proxy variable for financial liberalization is that it abstracts from the effects that work through the real interest rate, thus resolving any theoretical ambiguity about its sign.

Finally, the only remaining conceptual issue to be addressed concerns the definition of the dependent variable, i.e, the choice of an appropriate measure of private saving. Net saving is the relevant concept for measuring changes in net worth and the increment to the nation's capital stock. Gross saving is an accounting concept with no normative or behavioral interpretation, and would be an inappropriate measure of economic performance, especially given that depreciation allowances have risen in recent years. Thus, the study focuses on net private saving.

\section{Empirical specification and estimation}

A number of preliminary regressions were run to test the significance of the variables prescribed by economic theory. These regressions failed consistently to produce plausible wealth effects, and statistically significant coefficients for inflation. $2 / 3 /$

The following equation was estimated, using annual data for 1970-94: 4]

$$
\mathrm{SP}_{t}=\beta_{0}+\beta_{1} \mathrm{GROWTH}_{t}+\beta_{2} \mathrm{INCOME}_{t}+\beta_{3} \mathrm{AGE}_{\mathrm{t}}+\beta_{4} \mathrm{INT}_{\mathrm{t}}+\beta_{5} \mathrm{Sg}_{\mathrm{t}}+\beta_{6} \mathrm{FIN}_{\mathrm{t}}+\epsilon_{\mathrm{t}}
$$

where

Sp $\quad$ - private saving rate, defined as net private saving over net private disposable income;

IV In the case of Korea, small and medium-sized enterprises have also had difficulty in obtaining credit because of lack of adequate collateral, and, as a result, they were required to self-finance investment out of their own saving. More recently, government policies have facilitated the provision of credit to these enterprises thereby easing their borrowing constraints.

2/ The influence of net wealth and accrued capital gains were tested by the following proxies: the beginning-of-period stock of net financial assets of the private sector as a ratio to private income (using national accounts data), and changes in its value; and the stock-market index deflated by the CPI, to capture effects of capital gains in stocks. None of these variables produced statistically significant results.

3/ It seems that most of the influence of inflation on saving in Korea manifests itself through the real interest rate effect; once the latter is included in the regression, a separate variable accounting explicitly for the effects of inflation does not significantly add to the explanatory power of the equation.

4/ Detailed descriptions of the variables and data sources are provided in the appendix to the chapter. 


\begin{tabular}{|c|c|c|}
\hline GROWTH & $=$ & growth rate of per capita real private disposable income; \\
\hline INCOME & $=$ & $\begin{array}{l}\text { index of the level of per capita real private disposable } \\
\text { income relative to the United States; }\end{array}$ \\
\hline AGE & $=$ & age dependency ratio; \\
\hline INT & $=$ & expected real interest rate; \\
\hline $\mathbf{S g}$ & $=$ & government saving as a ratio to private disposable income; \\
\hline FIN & $=$ & proxy for financial liberalization; and, \\
\hline G & & stochastic error term with assumed standard propert \\
\hline
\end{tabular}

According to the theoretical framework discussed above, the expected signs of the coefficients are: $\beta_{1}$ and $\beta_{2}>0, \beta_{3}, \beta_{5}$, and $\beta_{6}<0$. The sign of $\beta_{4}$ is ambiguous depending on whether income or substitution effects are dominant. Finally $\beta_{5}=-1$ is a test of the validity of full Ricardian equivalence.

The equation was estimated by ordinary least squares (OLS) and twostage least squares (2SLS), in view of the simultaneous determination of the private saving rate and the income variables, the real interest rate, and the proxy variable for financial liberalization. 1/ Table IV.2 reports the results. All estimated coefficients are statistically significant at the five percent level, with signs that agree with prior expectations. The two estimation techniques produced similar results, suggesting small simultaneity bias and appropriate choice of instruments. The presence of first-order serial correlation was initially suspected as the Durbin-Watson test was inconclusive for OLS. Lagrange multiplier tests for the presence of up-to-second order serial correlation indicated the presence of firstorder positive serial correlation. The coefficients and statistics reported are based on the Cochrane-Orcutt method to correct for first-order serial correlation.

The coefficient of income growth indicates that a 1 percentage point rise in the rate of growth of per capita real income increases the average private saving rate by 0.48 percentage point. $2 /$ Over the sample period,

1 The choice of instruments involved: two lags of each of the endogenous variables (GROWTH, INCOME, INT, and FIN), real domestic investment, inflation, and the previous period's growth rate of the money supply; and, current values of the exogenous variables (AGE, and $\mathrm{Sg}$ ) as well as the percent change in Korea's terms of trade.

2/ References to regression results are from the 2SLS estimation. Numerical implications from point estimates should be treated with the required caution. 
Table IV.2. Korea: Determinants of Private Saving, Estimation Results, 1970-94 1/

\begin{tabular}{|c|c|c|}
\hline \multirow[t]{2}{*}{ Explanatory variable } & \multicolumn{2}{|c|}{ Estimated Coefficient } \\
\hline & OLS & 2SLS \\
\hline Constant & $\begin{array}{r}0.545 \\
(8.77)\end{array}$ & $\begin{array}{r}0.535 \\
(10.72)\end{array}$ \\
\hline GROWTH & $\begin{array}{r}0.395 \\
(4.96)\end{array}$ & $\begin{array}{r}0.481 \\
(5.64)\end{array}$ \\
\hline INCOME & $\begin{array}{r}0.282 \\
(5.57)\end{array}$ & $\begin{array}{r}0.296 \\
(6.90)\end{array}$ \\
\hline AGE & $\begin{array}{c}-0.466 \\
(6.22)\end{array}$ & $\begin{array}{l}-0.456 \\
(7.63)\end{array}$ \\
\hline INT & $\begin{array}{r}0.287 \\
(3.09)\end{array}$ & $\begin{array}{r}0.273 \\
(3.05)\end{array}$ \\
\hline $\mathbf{S g}_{\mathbf{g}}$ & $\begin{array}{r}-0.597 \\
(2.40)\end{array}$ & $\begin{array}{l}-0.516 \\
(2.30)\end{array}$ \\
\hline FIN & $\begin{array}{l}-0.279 \\
(6.64)\end{array}$ & $\begin{array}{r}-0.297 \\
(8.01)\end{array}$ \\
\hline
\end{tabular}

Sumary statistics:

Adjusted R-squared

0.931

0.954

$F(6,18)$

54.543

84.468

D-W

1.820

1.798

LM test for up-to-second order

serial correlation: $x^{2} 2$

4.803

4.433

CHOW (1988): $F(6,12)$

2.908

4.885

Source: Staff estimates.

1 Figures in parentheses are t-statistics. 
the growth rate of per capita real income averaged 6.4 percent, accounting, ceteris paribus, for an upward shift of the saving rate of about 3.1 percent from what it would otherwise have been.

The coefficient of the income index is positive and statistically significant. $1 /$ This result is consistent with the presence of liquidity constraints for a fraction of the population over the sample period. The hypothesis of the "hump-shaped" effect of income on saving was tested by running regressions using only the early part of the sample and increasingly adding observations and monitoring the evolution of the estimated coefficients. $2 /$ Indeed, the coefficient of income showed a marked decline of more than one third of its size when estimation was gradually extended to include the entire sample. This result could indicate, through the diminishing sensitivity of saving to current income, the gradual easing of liquidity constraints. $3 /$

The demographic variable showed a negative influence on the saving rate, as expected. 4/ The point estimate suggests that demographic factors account for a substantial part of the secular rise in the private saving rate. During the period 1970-94, the dependency ratio was halved, from about 84 percent in 1970 to just over 41 percent in 1994, raising the private saving rate by over 19 percentage points from where it would otherwise have been, given the influence of other factors. Unlike in other countries, the "baby boom" in Korea occurred during the mid-1950s to mid1960s, which implies that the "baby boom" generation is now at the prime of its working life. It will take several years before demographic factors reverse their effect on saving once that generation enters retirement age.

The positive sign and the magnitude of the coefficient of the real interest rate was consistent across a number of specifications. The statistical evidence suggests that substitution effects dominate income effects. The estimated coefficient implies a rather small positive elasticity of private saving with respect to expected real interest

1/ Collins (1994) found a statistically significant influence of anticipated income but only on the national saving rate.

$2 /$ Econometric estimation was carried out in AREMOS. The software allows for tracking the stability of the estimated coefflcients. Formal statistical tests for parametric stability are discussed later.

3/ In a parametric test for liquidity constraints in a number of countries, Haque and Montiel (1989) found that about one-fifth of households in Korea were liquidity constrained. Nam (1989) also found a diminishing sensitivity of saving to current income, using a quadratic formulation for current income.

4/ A regression which distinguished between the dependency ratio of the young and the retired failed to produce satisfactory results due to the high collinearity between the two demographic variables. 
rate. I/ If real interest rates were to decrease from their average level of about 8 percent over the sample period to 4 percent, the private saving rate would decline, on average, by just over one percentage point. The assumption that financial liberalization increases the sensitivity of saving to real interest rate changes was tested with the same technique employed for the coefficient of the income index, namely a sequence of rolling regressions. The results support this assumption. The coefficient of the real interest rate increased by over one third from regressions which utilized only the first half of the sample. $2 /$

Government saving has a statistically significant negative effect on private saving. However, the null hypothesis of full Ricardian equivalence (i.e., $\beta_{5}=-1$ ) was rejected at the one percent level of significance. The estimated equation suggests that private saving in Korea only partially offsets government dissaving. On average, a 1 percentage point decline in the government saving rate would induce private agents to raise their average saving rate by 0.52 percentage point. $\underline{3} /$

The estimated coefficient of the proxy variable for financial liberalization implies that increased provision of credit to the private sector may have reduced the need for saving. Since 1988, when the private saving rate reached its peak, outstanding credit to the private sector has increased sharply from 83 percent of GDP to 133 percent of GDP in 1994. This increase would have, ceteris paribus, reduced the private saving rate by nearly 15 percentage points during this period. According to the regression, this probably explains the actual decline in the private saving rate since 1988, notwithstanding the positive influence from other factors.

Given the strong indications of an apparent effect of financial liberalization on private saving behavior, the hypothesis of a structural break in the estimated relationship in 1988 was tested formally with a Chow test for parametric stability (results of the test are reported in the last line of Table IV.2). The null hypothesis of no structural break in 1988 could not be rejected for the OLS regression at the five percent level but was rejected for the 2SLS regression. However, the latter result should be viewed with a degree of skepticism for two reasons. First, the result was not robust across different specifications: the hypothesis of no structural

1 Collins (1994) estimated a very similar coefficient for Korea. Nam's (1989) estimates, derived from a household saving function, were somewhat lower. On the other hand, Giovannini's (1985) estimation of a consumption function for Korea failed to produce a statistically significant effect of real interest rates.

2/ This result is consistent with the empirical evidence provided by Ogaki et al. (1995), who found in a study of low-and middle-income countries that the real interest rate elasticity of saving increases with the level of development and income of the country.

3/ Corbo and Schmidt-Hebbel (1991) found a similar response in their study of public policies in developing countries. 
break in 1987 or 1989 --or any other year for that matter which did not represent such an extreme deviation from the trend--could not be rejected for the 2SLS regression as well as a host of other specifications. This points to non-robustness of such inferences owing to the short estimation periods. And, second, the choice to test the hypothesis at 1988 (at the kink of the private-saving rate curve) was very artificial because liberalization measures were phased in, and no single year represented a significant departure from the previous structure of the financial system. However, given the ambiguity of the result and the importance of the hypothesis tested, ideally one should try to retest the hypothesis with additional observations.

\section{A simulation exercise}

The preceding analysis has pointed to the liberalization of the financial system as a likely reason for the decline in the private saving rate in recent years. In this section, a simple static simulation exercise is undertaken with the main objective of investigating whether the private saving rate in Korea is likely to be sustained at the current level over the medium term. Rather than trying to forecast the private saving rate, this exercise intends to evaluate the effects of the contribution of current trends in the explanatory variables. Two counterfactual scenarios are also computed to illustrate the impact on private saving of certain government policies. The estimated regression equation was used to derive the path of private saving. $1 /$

\section{a. Baseline scenario}

A baseline scenario was formulated through the year 2000 , assuming the return of the economy to its long-run growth path, and current or announced future policies. In designing the baseline scenario, projected values for a number of variables were taken from other sources. In particular, the two income variables were derived from information in the Fund's Summer 1995 WEO database, after certain adjustments were made to match the definitions used in this chapter (Table IV.3 summarizes the data used in this exercise). United Nations projections of population and age-dependency ratios were used to establish anticipated demographic trends. The remaining variables were either treated as policy variables (government saving, and the proxy for financial liberalization) or assumed to be largely determined by certain government policies (the real interest rate).

The baseline scenario assumes that the government saving rate and the private credit variable continue their gradual upward movement along the fairly constant trends of the last ten years. The rise in the former is consistent with the Government's medium-term fiscal objective to raise spending on social overhead capital, which is to be financed by reducing

1/ Both estimated regressions in Table IV.2 yielded similar results. We only report the results obtained from the 2 sLs equation. 
Table IV.3. Korea: Simulation of the Private Saving Rate, 1970-2000 I/

\begin{tabular}{|c|c|c|c|c|c|c|c|}
\hline & Sp & GROWTH & INCOME & AGE & INT & $\mathbf{S g}$ & FIN \\
\hline $\begin{array}{l}1970-79 \\
1980-89 \\
1990-94 \\
1994\end{array}$ & $\begin{array}{l}.139 \\
.200 \\
.244 \\
.233\end{array}$ & $\begin{array}{l}.066 \\
.062 \\
.063 \\
.067\end{array}$ & $\begin{array}{r}.111 \\
.404 \\
.874 \\
1.000\end{array}$ & $\begin{array}{l}.735 \\
.534 \\
.430 \\
.415\end{array}$ & $\begin{array}{l}.072 \\
.077 \\
.083 \\
.071\end{array}$ & $\begin{array}{l}.049 \\
.081 \\
.112 \\
.126\end{array}$ & $\begin{array}{r}.405 \\
.756 \\
1.156 \\
1.326\end{array}$ \\
\hline \multicolumn{8}{|c|}{ Baseline scenario } \\
\hline $\begin{array}{l}1995-2000 \\
2000\end{array}$ & $\begin{array}{l}.247 \\
.244\end{array}$ & $\begin{array}{l}.063 \\
.060\end{array}$ & $\begin{array}{l}1.252 \\
1.441\end{array}$ & $\begin{array}{l}.406 \\
.405\end{array}$ & $\begin{array}{l}.047 \\
.030\end{array}$ & $\begin{array}{l}.141 \\
.153\end{array}$ & $\begin{array}{l}1.491 \\
1.646\end{array}$ \\
\hline & \multicolumn{7}{|c|}{ Alternative scenario I } \\
\hline \multirow[t]{2}{*}{$\begin{array}{l}1995-2000 \\
2000\end{array}$} & $\begin{array}{l}.215 \\
.204\end{array}$ & $\begin{array}{l}.058 \\
.055\end{array}$ & $\begin{array}{l}1.230 \\
1.401\end{array}$ & $\begin{array}{l}.406 \\
.405\end{array}$ & $\begin{array}{l}.043 \\
.030\end{array}$ & $\begin{array}{l}.146 \\
.161\end{array}$ & $\begin{array}{l}1.560 \\
1.728\end{array}$ \\
\hline & & \multicolumn{6}{|c|}{ Alternative scenario II } \\
\hline $\begin{array}{l}1995-2000 \\
2000\end{array}$ & $\begin{array}{l}.254 \\
.267\end{array}$ & $\begin{array}{l}.063 \\
.060\end{array}$ & $\begin{array}{l}1.252 \\
1.441\end{array}$ & $\begin{array}{l}.406 \\
.405\end{array}$ & $\begin{array}{l}.065 \\
.061\end{array}$ & $\begin{array}{l}.137 \\
.145\end{array}$ & $\begin{array}{l}1.464 \\
1.563\end{array}$ \\
\hline
\end{tabular}

Source: Staff calculations.

1 Figures are averages over the specified periods. Units correspond. to the definitions provided in the appendix to this chapter. 
inessential spending on current operations and by mobilizing resources through broadening the tax base. Furthermore, real interest rates are assumed to gradually converge from their present level of over 7 percent to projected international levels of around 3 percent by the year 2000 . This is consistent with the authorities' plan to gradually open the capital account, which should eventually eliminate the gap between domestic and international real interest rates.

\section{b. Alternative scenario I}

This is a low-private-saving scenario. It assumes that the authorities move ahead of schedule in opening the capital account, and as a result, the adjustment of real interest rates is more front-loaded and fully completed by 1999. Moreover, the inflow of foreign saving permits the extension of additional credit to the private sector to finance consumption or investment. By the year 2000, the stock of outstanding credit to the private sector would thus be 5 percent higher than in the baseline scenario. Government saving will also be higher over the medium term, under the assumption that the authorities accelerate their current program of investment in infrastructure. For this purpose, the Government would need to achieve by the year 2000 additional saving of 5 percent relative to the level assumed in the baseline scenario (or, equivalently, an increase in its saving rate of almost one percentage point). . The improved current position of the Government would be achieved through further reductions in current expenditure and increases in the tax burden. "Although the simulations are static and ignore interactions between variables, a pseudo-second-round feature was added to this experiment: it was assumed that the increased tax obligations would fall on private disposable incomes, thus affecting both the level and the growth rate of income. Specifically, it was assumed that the annual growth rate of per capita real private disposable income would be 0.5 percentage point lower than in the baseline scenario.

\section{c. Alternative scenario II}

This is a high-private-saving scenario. It assumes that the authorities move slowly to open the capital account. As a result, the real interest rate differential between Korea and the rest of the world would be reduced by only one percentage point over the medium term. High domestic interest rates would be reflected in lower demand for private credit and, as a result, the outstanding stock of private credit in the year 2000 would be 5 percent lower than the stock in the baseline scenario. To ensure uninterrupted flow of financing to small- and medium-sized enterprises, the Government provides subsidies which raise current expenditure, and consequently government saving turns out 5 percent lower by the year 2000 relative to the level assumed in the baseline scenario. Unlike scenario $I$, no effects on private incomes were assumed. 


\section{d. Simulation results}

Simulation results are presented in Table IV. 3 and Chart IV. 3 . The baseline scenario projects a stabilization of the private saving rate at a level which is about 1 percentage point higher in the year 2000 than at present. Following an initial jump of about 2.5 percentage points in 1995 -owing to projected above-potential growth--the saving rate will gradually converge to a stable trajectory, reflecting the return of the economy to its long-run path. Without ignoring the limitations of this static exercise, a partial equilibrium analysis of the effect of lower real interest rates following the gradual opening of the capital account indicates that this factor would have a negligible effect on the private saving rate. Consistent with the regression estimate of a low real interest rate semielasticity of private saving of about 0.3 , the reductions in real interest rates assumed in the baseline scenario would keep the private saving rate, other things constant, at about 0.2 percentage point lower every year.

The first alternative scenario projects a decline in the private saving rate of 4 percentage points over the medium term, against the outcome in the baseline scenario. Increased availability of credit to the private sector accounts for most of the decline. The second alternative scenario projects a rise in the private saving rate to just under 27 percent by the year 2000, 2.3 percentage points higher than in the baseline scenario. Again, the private credit variable was the most influential in driving the change in the private saving rate.

\section{Conclusion}

This study examined private saving behavior in Korea over the last 25 years. A life-cycle model of saving behavior was estimated, allowing for liquidity constraints and bequest motives. A proxy for financial liberalization was used, and the effects of gradually eased liquidity constraints were observed through the diminishing sensitivity of private saving to current income and increasing sensitivity to real interest rates.

The results indicate that demographic and income factors account for most of the secular rise in the private saving rate over the last 25 years. The evidence did not provide support for a full Ricardian equivalence effect; therefore, the results suggest that the Government can raise national saving by increasing government saving. The study found that changes in real interest rates have a positive, albeit small, effect on the private saving rate.

The findings support the hypothesis that financial liberalization has affected private saving behavior. However, given the gradual process of financial liberalization, the statistical evidence in favor of the hypothesis of a clear structural break in private saving behavior was weak.

A simple simulation exercise was undertaken to investigate the mediumterm path of the private saving rate, under the assumption of continuing 
current trends. The exercise suggests that the private saving rate will remain, on average, at about the same level it has been in recent years. significant changes in demographic factors are projected over the medium term which might impact the private saving rate in an adverse way. 
PRIVATE SAVING, MEDIUM-TERM PROSPECTS, 1980-2000

(In percent of net private disposable income)

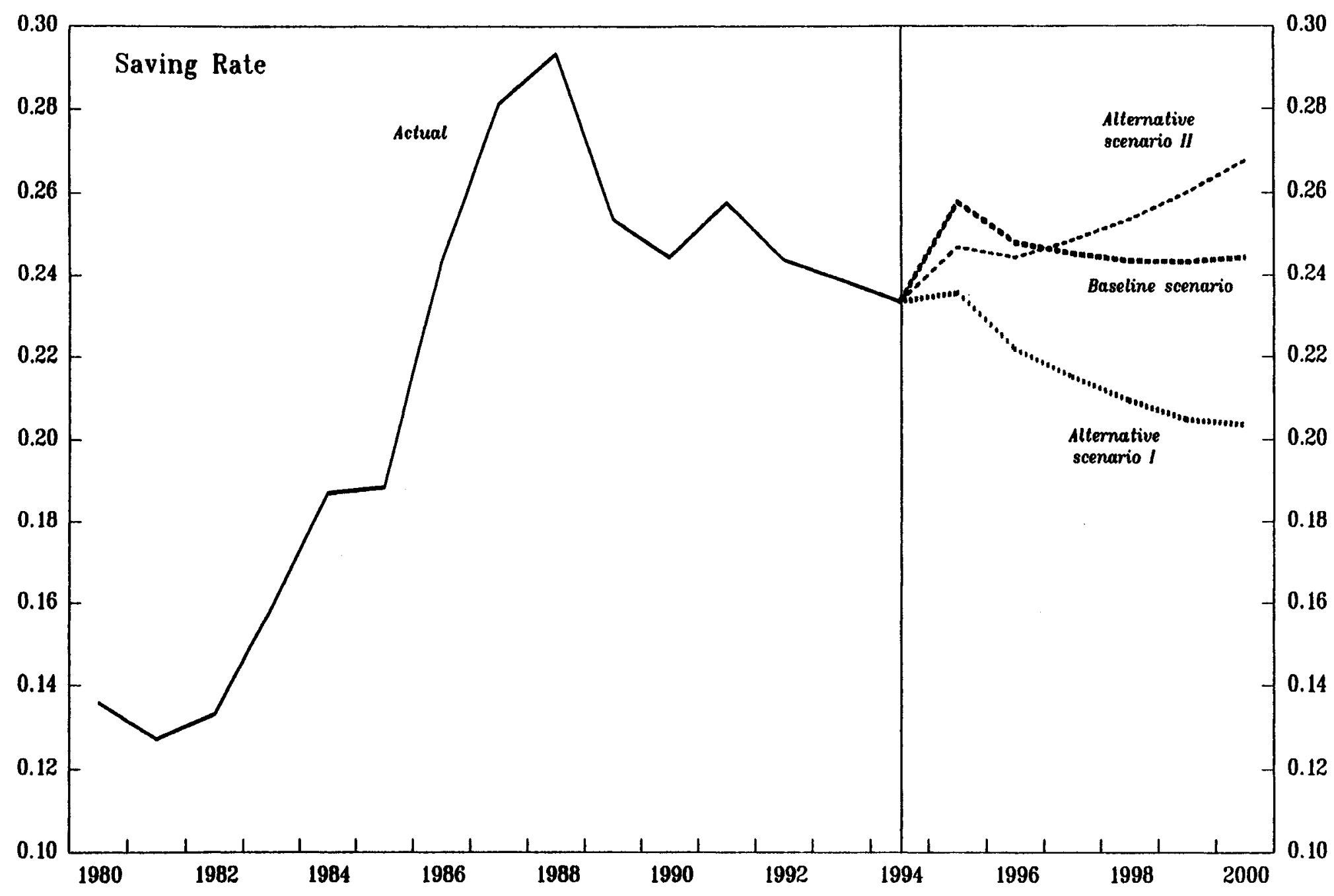

Sources: Bank of Korea, National Accounts; and staff calculations.

CInternational Monetary Fund. Not for Redistribution 


\section{Definitions of Variables and Data Sources}

Variable

Sp

GROWTH

INCOME

AGE

INT

$S_{g}$

FIN

Definition

Private saving rate: net private saving at current prices divided by net private disposable income at current prices.

Growth rate of per capita real net private disposable income, expressed as a proportion rather than a percentage.

Real-income index: derived as per capita net private disposable income (at 1990 constant prices) divided by per capita national income of the U.S. (at 1990 constant prices) times the exchange rate, and indexed to range from 0 to 1.

Age dependency ratio: number of people under 15 and over 64 years of age, divided by the number of people between 15 and 64 years of age.

Real interest rate: yield on corporate bonds less a weighted average of present and two lags of consumer price inflation rates (annual average).

Government saving: net government saving at current prices divided by net private disposable income at current prices.

Proxy for financial liberalization: ratio of outstanding stock of private sector credit at current prices (period average) to GDP at current prices.

\section{Data Sources}

Data for Sp, GROWTH, INCOME, and Sg are from: Bank of Korea, "National Accounts" (various issues). Data for the U.S. are from: International Monetary Fund, "International Financial Statistics" (various issues). Data for AGE are from: National Statistical Office, "Social Indicators in Korea" (various issues). Data for INT and FIN are from: Bank of Korea, "Monthly Statistical Bulletin" (various issues). Population projections for the simulation exercise were obtained from: United Nations, "World Population Prospects", 1992 revision. 


\section{References}

Ando, A., and F. Modigliani (1963), "The 'Life Cycle' Hypothesis of Saving: Aggregate Implications and Tests," American Economic Review, Vol. 53, pp. 55-84.

Barro, R. J. (1974), "Are Government Bonds Net Wealth?," Journal of Political Economy, Vol. 82; pp. 1095-1177.

Chandavarkar, A. (1993), "Saving Behaviour in the Asian-Pacific Region," Asian-Pacific Economic Literature, Vol. 7, pp. 9-27.

Collins, S. M. (1994), "Saving, Investment, and External Balance in South Korea," in S. Haggard et al. (eds.), Macroeconomic Policy and Adjustment in Korea, 1970-1990, Harvard Institute for International Development.

Corbo, V., and K. Schmidt-Hebbel (1991), "Public Policies and Saving in Developing Countries," Journal of Development Economics, Vol. 36, pp. 89-115.

Giovannini, A. (1985), "Saving and the Real Interest rate in LDCs," Journal of Development Economics, Vol. 18, 197-217.

Haque, N. U., and P. Montiel (1989), "Consumption in Developing Countries: Tests for Liquidity Constraints and Finite Horizons," The Review of Economics and Statistics, Vol 71., pp. 408-15.

Jappe11i, T., and M. Pagano (1992), "Saving, Growth and Liquidity Constraints," Centre for Economic Policy Research, Discussion Paper No. 662 .

Lahiri, A. K. (1989), "Dynamics of Asian Savings: The Role of Growth and Age Structure," IMF Staff Papers, Vol. 36, pp. 228-61.

Nam, S. W. (1989), "What Determines National Saving? A Case Study of Korea and the Philippines," World Bank Working Papers, WPS 205.

(1990), "A Sectoral Accounting Approach to National Savings Applied to Korea," Journal of Development Economics, Vol. 33, Pp. 31-52.

Ogaki, M., J. D. Ostry and C. M. Reinhart (1995), "Saving Behavior in Lowand Middle-Income Developing Countries: A Comparison," IMF Working Paper, WP/95/3.

Yusuf, S., and K. R. Peters (1984), "Savings Behavior and its Implications for Domestic Resource Mobilization: The Case of the Republic of Korea," World Bank Staff Working Papers, No. 628. 


\section{Output, Prices and the Balance of Payments--A Medium-Term Scenario 1/}

This chapter discusses a simple medium-term scenario for the Korean economy. It focusses on the outlook for output, prices, and the balance of payments, and is based on the assumption that policies will be implemented as currently planned, in the macroeconomic area as well as in the area of structural reform.

Even though estimates of potential output tend to be subject to considerable error margins, they provide a rough measure of the growth rate that can be sustained over the medium term without creating price pressures. A revision and extension of previous estimates of potential output $2 /$ suggests that this rate is at present about $71 / 2$ percent for Korea. This estimate is somewhat higher than previous estimates of potential GDP growth for the period 1994-98 but still considerably lower than the 9 percent estimated for the second half of the 1980s. The revisions take into account the recent surge in investment, which raised the investment ratio from 35 percent of GDP in 1993 to nearly 36 percent in 1994, with a further increase to $371 / 2$ percent projected for 1995 . Over the medium term, the investment ratio is expected to stabilize at just under 38 percent, sustained by a gradual improvement in financing conditions as capital flows are being liberalized. $3 /$

The strength of investment is reflected in a somewhat larger contribution of capital to estimated potential output growth ( 5.2 percentage points on average during 1995-2000 compared with an earlier estimate of 4.9 percentage points for 1995-98). In addition, revised estimates of the trend growth of total factor productivity (TFP) suggest a somewhat larger contribution of productivity growth (1.4 percentage points compared with 1.1 percentage points estimated previously). Finally, the estimate of the contribution of labor remains unchanged ( 0.9 percentage points).

With actual growth in 1994 and so far in 1995 exceeding potential by a considerable margin, the negative output gap that emerged in the 1992-93 recession is likely to have been closed and output for 1995 as a whole may turn out somewhat above potential (Table V.1). However, the positive output gap is expected to be small, and, on planned policies, unlikely to increase further in 1996 as growth slows and reaches the neighborhood of potential. The moderation of growth in 1996 would set the stage for a sustained expansion at the rate of potential over the medium term. Such a growth path would be consistent with a gradual further reduction of inflation over the medium term, as envisaged by the Government, from 5 percent in 1995 to 3 percent by 2000 .

1) Prepared by Marianne Schulze-Ghattas.

2/ See "Korea--Recent Economic Developments" (SM/94/229, 8/29/94) for a detailed discussion of these estimates.

3/ The investment to GDP ratio reached a historical peak of almost 39 percent in 1991. 
Table V.1. Korea: A Medium-Term Scenario (Annual percentage change, unless indicated otherwise)

\begin{tabular}{|c|c|c|c|c|}
\hline & 1994 & 1995 & 1996 & $1997-20001$ \\
\hline $\begin{array}{l}\text { Real GDP } \\
\text { Total consumption } \\
\text { Fixed investment } \\
\text { Foreign balance } 2\end{array}$ & $\begin{array}{r}8.4 \\
7.0 \\
11.7 \\
-1.8\end{array}$ & $\begin{array}{r}9.7 \\
8.2 \\
13.2 \\
-0.3\end{array}$ & $\begin{array}{l}7.6 \\
7.2 \\
7.1 \\
0.3\end{array}$ & $\begin{array}{r}7.5 \\
7.5 \\
7.5 \\
--\end{array}$ \\
\hline Consumer prices & 6.3 & 5.0 & 4.5 & 3.5 \\
\hline $\begin{array}{l}\text { Gross domestic investment } 3 / 4 / \\
\text { Gross national saving } 3 / \\
\text { Current account } 3 /\end{array}$ & $\begin{array}{l}35.9 \\
35.0 \\
-1.2\end{array}$ & $\begin{array}{l}37.7 \\
35.7 \\
-2.0\end{array}$ & $\begin{array}{l}37.5 \\
35.8 \\
-1.7\end{array}$ & $\begin{array}{l}37.9 \\
36.4 \\
-1.5\end{array}$ \\
\hline $\begin{array}{l}\text { Export volume } \\
\text { Import volume }\end{array}$ & $\begin{array}{l}14.9 \\
21.5\end{array}$ & $\begin{array}{l}16.9 \\
17.5\end{array}$ & $\begin{array}{r}10.5 \\
9.5\end{array}$ & $\begin{array}{l}9.3 \\
9.2\end{array}$ \\
\hline $\begin{array}{l}\text { Debt-to-GDP ratio } \\
\text { Debt-service ratio } 5 /\end{array}$ & $\begin{array}{r}14.7 \\
6.2\end{array}$ & $\begin{array}{r}14.1 \\
5.5\end{array}$ & $\begin{array}{r}14.0 \\
5.3\end{array}$ & $\begin{array}{r}14.0 \\
5.5\end{array}$ \\
\hline
\end{tabular}

Source: Staff estimates.

1. Average of annual figures

2) Contribution to GDP growth.

3/ In percent of GDP.

4/ Total investment.

5/ In percent of exports of goods and nonfactor services. 
As growth converges to the growth rate of potential, the composition of demand is projected to shift. In particular, fixed investment--which expanded at a double-digit rate in 1994 and, according to current projections, will probably do so again this year--is expected to moderate and grow in line with output over the medium term. At the same time, consumption, which has picked up only recently after lagging behind output growth in 1993-94, is expected to be sustained over the medium term at the rate of growth of potential output. This would imply a broadly stable national savings ratio of $361 / 2$ percent over the medium term.

The projected medium-term path of saving and investment implies a current account deficit of about $11 / 2$ percent of GDP, somewhat smaller than the deficit projected for 1995 (2 percent of GDP), which reflects special cyclical factors such as the buoyancy of investment expenditure with a high import content. Assuming income elasticities of export and import demand of 2.5 and 1.5 , respectively, $1 /$ and taking into account the projected growth in Korea and in partner countries, $2 /$ the projected current account balance would be consistent with the real effective exchange rate remaining broadly unchanged at the level of August 1995, which is close to the level of December 1994 .

With the planned gradual opening of the capital account, a substantial part of the current account deficit would be financed by non-debt-creating flows, notably further inflows into the stock market as the ceiling is being raised, and, on a limited scale, into the bond market. While foreign borrowing would be higher than in the early 1990s, the resulting growth of foreign debt would be broadly in line with GDP growth, with the debt to GDP ratio stabilizing at about 14 percent, and the debt service ratio at about $51 / 2$ percent of exports of goods and nonfactor services.

1) These elasticities are within the range of available estimates. See "Korea--Recent Economic Developments," (SM/94/229, 8/29/94) for an econometric analysis of Korean exports and imports.

2/ The World Economic Outlook projects real GDP growth of 4 percent for Korea's partner countries. 


\section{The Inflation Process in Korea 1/}

\section{Introduction}

A notable feature of the present expansion in Korea is the subdued behavior of inflation. Recent price developments bear some similarities with developments in the expansion of 1986-88, and contrast markedly with the more rapid acceleration of inflation in the 1990-91 expansion. Given broadly similar rates of monetary growth $2 /$ and a similar degree of overall resource pressures as measured by the estimated output gaps, the question arises why price behavior has differed in these expansions. One factor accounting for the differences appears to be the structure of the expansions. While the expansion of 1990-91 was mainly concentrated in the nontraded goods sectors such as construction and services, the present expansion, as that of 1986-88, has been led by strong growth in the manufacturing sector, stimulated by buoyant exports. 3 Another important factor appears to be differences in wage behavior.

This chapter analyzes the inflation process in Korea since the early 1980s. The analysis focusses on the behavior of wages and prices in the traded and nontraded goods sectors and takes the factors that affect the level and the composition of demand, including monetary policy, as given. Section 2 briefly describes the main features of recent expansions: their structure and developments in wages and prices. Section 3 develops a simple model for the analysis of the wage-price mechanism in a small open economy. Section 4 discusses some stylized facts of the process of wage and price determination in Korea. Section 5 presents estimation results for wage and price equations for the traded and nontraded goods sectors, and section 6 summarizes the main conclusions of the chapter.

1) Prepared by Marianne Schulze-Ghattas.

2/ While in the 1970s, rapid monetary growth fuelled by extensive policybased lending played an important role in the inflation process, in the 1980 s the focus of monetary policy shifted toward stabilization and monetary growth was brought down. As a result of this reorientation, inflation declined from an average of 16 percent in the 1970s to just over 5 percent during 1983-94. Since the mid 1980s, monetary policy has generally attempted to strike a balance between accommodation and restraint. Even though monetary control was complicated by large shifts in the balance of payments position, monetary policy generally succeeded in insulating domestic monetary conditions through extensive sterilization operations.

3/ While the degree of exposure to foreign competition varies among industries in the manufacturing sector, the sector as a whole can be identified with the traded goods sector. 


\section{Wage and price behavior in recent expansions}

Since the mid-1980s Korea has experienced three economic expansions: in 1986-88, in 1990-91, and, most recently, since late 1993. These three expansions have been broadly similar in term of the estimated overall output gaps (Table VI.1) and average rates of money growth. M2 averaged 18.1 percent in 1986-88, 19.8 percent in 1990-91, and 16.5 percent in 1994 and the first half of 1995. Average consumer price inflation, however, was more than twice as high in 1990-91 ( 9 percent) as in 1986-88 (4.3 percent), and was 5.5 percent in 1994 and the first half of 1995 . The expansions have also differed in a number of other important aspects: the composition of demand, the sectoral contributions to growth, and the behavior of wages. $1 /$

Both, the boom of 1986-88 and the most recent expansion, were led by rapid export growth, reflecting strong demand in partner countries as well as gains in competitiveness (Chart VI.1). $2 /$ Buoyant investment activity in 1986-88, and even more so in the present expansion, reflected largely strong equipment investment, with construction growing at a more moderate pace. In both expansions, private consumption lagged behind the growth of overall economic activity. However, the composition of demand changed in the course of the 1986-88 expansion with construction investment and consumption picking up, and there are indications that a similar shift is now under way.

In contrast to these expansions, the boom of 1990-91 was driven by domestic demand. Construction investment accelerated sharply, stimulated by expansionary financial policies, which sought to offset the faltering of exports following a sharp appreciation of the real effective exchange rate in 1988-89. Private consumption was boosted by large income gains due to a sharp acceleration of wage increases since 1988. The composition of demand shifted only in the latter part of the expansion, with construction and private consumption moderating and exports recovering.

1 They also differed significantly in terms of the external positions. In particular, while the current account registered large surpluses in the expansion of 1986-88, both the expansion of 1990-91 and the most recent one have featured current account deficits.

2) While gains in competitiveness in the mid 1980 s were associated with a sharp depreciation of the won in real effective terms during 1985-86, the decline in the real effective exchange rate since the early 1990 s has been relatively moderate. In both periods, however, the won depreciated significantly against the yen. The differences in the response of exports to changes in the real effective exchange rate may be due to changes in the geographical distribution of Korean exports, which are not captured in the weights of the real exchange rate index. They may also be due to changes in the commodity composition of exports, which imply shifts in the response to a given change in partner countries' exchange rates. 
Table VI.1. Korea: Growth, Wages, and Prices, 1985-95

(Percent chmie per mom, uniess othemise indicated)

\begin{tabular}{|c|c|c|c|c|c|c|c|c|c|c|c|}
\hline & 1985 & 1986 & 1987 & 1988 & 1989 & 1990 & 1991 & 1992 & 1993 & 1994 & $\begin{array}{c}19951 / \\
\text { Q1 }\end{array}$ \\
\hline $\begin{array}{l}\text { Real GDP } \\
\text { Private consumption } \\
\text { Fixed investment } \\
\text { Equipunt } \\
\text { Construction } \\
\text { Exports } \\
\text { Imports }\end{array}$ & $\begin{array}{r}6.6 \\
6.2 \\
4.4 \\
4.9 \\
4.2 \\
4.6 \\
-0.6\end{array}$ & $\begin{array}{r}11.6 \\
8.2 \\
10.6 \\
23.8 \\
2.6 \\
26.5 \\
17.9\end{array}$ & $\begin{array}{r}11.5 \\
8.1 \\
17.0 \\
19.1 \\
15.5 \\
21.7 \\
19.6\end{array}$ & $\begin{array}{r}11.3 \\
8.9 \\
13.7 \\
13.1 \\
14.3 \\
12.6 \\
13.0\end{array}$ & $\begin{array}{r}6.4 \\
10.9 \\
15.9 \\
14.2 \\
16.8 \\
-4.1 \\
16.3\end{array}$ & $\begin{array}{r}9.5 \\
10.7 \\
25.9 \\
19.0 \\
31.2 \\
4.2 \\
14.3\end{array}$ & $\begin{array}{r}9.1 \\
9.5 \\
12.6 \\
12.1 \\
13.0 \\
11.8 \\
19.3\end{array}$ & $\begin{array}{r}5.1 \\
6.6 \\
-0.8 \\
-1.1 \\
-0.6 \\
11.0 \\
5.1\end{array}$ & $\begin{array}{r}5.8 \\
5.8 \\
5.2 \\
-0.2 \\
8.9 \\
11.3 \\
6.7\end{array}$ & $\begin{array}{r}8.4 \\
7.5 \\
11.7 \\
23.5 \\
4.6 \\
16.2 \\
21.8\end{array}$ & $\begin{array}{r}9.9 \\
8.9 \\
15.6 \\
25.2 \\
8.0 \\
23.8 \\
22.9\end{array}$ \\
\hline $\begin{array}{l}\text { Value added in private } \\
\text { nonfarm sector } 2 / \\
\text { Manufacturins } \\
\text { Other sectors } 3 / \\
\text { Of which: Construction }\end{array}$ & $\begin{array}{l}7.7 \\
6.2 \\
8.5 \\
5.6\end{array}$ & $\begin{array}{r}13.9 \\
19.5 \\
11.1 \\
3.1\end{array}$ & $\begin{array}{l}15.4 \\
19.6 \\
13.2 \\
12.8\end{array}$ & $\begin{array}{r}12.3 \\
13.8 \\
11.5 \\
8.6\end{array}$ & $\begin{array}{r}7.5 \\
4.2 \\
9.4 \\
14.7\end{array}$ & $\begin{array}{r}11.7 \\
9.7 \\
12.8 \\
25.7\end{array}$ & $\begin{array}{r}10.5 \\
9.1 \\
11.3 \\
14.8\end{array}$ & $\begin{array}{r}5.1 \\
5.1 \\
5.1 \\
-0.7\end{array}$ & $\begin{array}{l}6.8 \\
5.0 \\
7.7 \\
8.4\end{array}$ & $\begin{array}{r}9.5 \\
10.4 \\
9.1 \\
4.6\end{array}$ & $\begin{array}{r}10.8 \\
12.9 \\
9.7 \\
7.8\end{array}$ \\
\hline $\begin{array}{l}\text { Output gap 4/ } \\
\text { Unewployment rate } \\
\text { Unewployment gap 6/ }\end{array}$ & $\begin{array}{r}-3.4 \\
4.0 \\
0.4\end{array}$ & $\begin{array}{r}-1.2 \\
3.8 \\
0.4\end{array}$ & $\begin{array}{r}2.5 \\
3.1 \\
-0.1\end{array}$ & $\begin{array}{r}3.7 \\
2.5 \\
-0.5\end{array}$ & $\begin{array}{r}0.8 \\
2.6 \\
-0.2\end{array}$ & $\begin{array}{r}2.3 \\
2.4 \\
-0.3\end{array}$ & $\begin{array}{r}3.2 \\
2.3 \\
-0.3\end{array}$ & $\begin{array}{r}-0.6 \\
2.4 \\
-0.1\end{array}$ & $\begin{array}{r}-2.5 \\
2.8 \\
0.4\end{array}$ & $\begin{array}{r}-1.7 \\
2.4 \\
0.1\end{array}$ & $\begin{array}{r}-\overline{2} \\
-0.2\end{array}$ \\
\hline $\begin{array}{l}\text { Wages in private } Z / \\
\text { nonfarm sector } \\
\text { Manufacturing } Z / \\
\text { Other I/ }\end{array}$ & $\begin{array}{r}10.2 \\
11.1 \\
9.6\end{array}$ & $\begin{array}{l}7.1 \\
7.1 \\
7.1\end{array}$ & $\begin{array}{r}11.3 \\
13.2 \\
9.9\end{array}$ & $\begin{array}{l}17.4 \\
22.9 \\
13.1\end{array}$ & $\begin{array}{l}25.7 \\
30.2 \\
22.0\end{array}$ & $\begin{array}{l}21.2 \\
22.3 \\
20.2\end{array}$ & $\begin{array}{l}18.2 \\
17.9 \\
18.6\end{array}$ & $\begin{array}{l}16.1 \\
16.9 \\
15.4\end{array}$ & $\begin{array}{l}12.5 \\
10.8 \\
13.9\end{array}$ & $\begin{array}{l}12.5 \\
14.9 \\
10.3\end{array}$ & $\begin{array}{c}\ldots 0 \\
\ldots .0\end{array}$ \\
\hline $\begin{array}{l}\text { Productivity in nonfarm sector } 8 / \\
\text { Manufacturins } \\
\text { Other } \underline{3} /\end{array}$ & $\begin{array}{l}1.0 \\
2.5 \\
0.3\end{array}$ & $\begin{array}{l}6.4 \\
7.5 \\
5.9\end{array}$ & $\begin{array}{l}7.0 \\
5.0 \\
7.9\end{array}$ & $\begin{array}{r}8.2 \\
10.5 \\
6.4\end{array}$ & $\begin{array}{l}5.5 \\
3.6 \\
6.4\end{array}$ & $\begin{array}{r}7.8 \\
11.0 \\
6.2\end{array}$ & $\begin{array}{l}5.7 \\
8.2 \\
4.3\end{array}$ & $\begin{array}{r}3.1 \\
9.9 \\
-0.1\end{array}$ & $\begin{array}{l}3.8 \\
9.0 \\
2.0\end{array}$ & $\begin{array}{l}4.2 \\
8.9 \\
2.6\end{array}$ & $\ddot{7.5}$ \\
\hline $\begin{array}{l}\text { Consumer prices } \\
\text { Excluding agricultural products } \\
\text { Manufacturing products } \\
\text { Services }\end{array}$ & $\begin{array}{l}2.4 \\
2.1 \\
0.8 \\
2.9\end{array}$ & $\begin{array}{l}2.8 \\
3.0 \\
2.0 \\
4.0\end{array}$ & $\begin{array}{l}3.1 \\
3.0 \\
2.6 \\
3.2\end{array}$ & $\begin{array}{l}7.1 \\
5.8 \\
2.9 \\
6.5\end{array}$ & $\begin{array}{l}5.7 \\
5.5 \\
4.8 \\
5.6\end{array}$ & $\begin{array}{l}8.6 \\
8.0 \\
5.1 \\
9.6\end{array}$ & $\begin{array}{r}9.3 \\
8.4 \\
4.8 \\
12.0\end{array}$ & $\begin{array}{l}6.2 \\
6.7 \\
4.2 \\
9.0\end{array}$ & $\begin{array}{l}4.8 \\
5.6 \\
3.9 \\
7.1\end{array}$ & $\begin{array}{l}6.3 \\
4.9 \\
3.1 \\
6.5\end{array}$ & $\begin{array}{l}4.6 \\
4.2 \\
1.7 \\
6.3\end{array}$ \\
\hline $\begin{array}{l}\text { Producer prices } \\
\text { Excluding asriculturel products }\end{array}$ & $\begin{array}{l}0.9 \\
0.5\end{array}$ & $\begin{array}{l}-1.5 \\
-1.5\end{array}$ & $\begin{array}{l}0.5 \\
0.6\end{array}$ & $\begin{array}{l}2.7 \\
1.5\end{array}$ & $\begin{array}{l}1.5 \\
1.3\end{array}$ & $\begin{array}{l}4.2 \\
3.1\end{array}$ & $\begin{array}{l}4.7 \\
3.9\end{array}$ & $\begin{array}{l}2.2 \\
2.0\end{array}$ & $\begin{array}{l}1.5 \\
1.5\end{array}$ & $\begin{array}{l}2.7 \\
1.5\end{array}$ & $\begin{array}{l}4.2 \\
4.1\end{array}$ \\
\hline $\begin{array}{l}\text { Export prices } \\
\text { Import prices }\end{array}$ & $\begin{array}{l}5.3 \\
3.7\end{array}$ & $\begin{array}{r}4.7 \\
-4.3\end{array}$ & $\begin{array}{l}2.3 \\
7.1\end{array}$ & $\begin{array}{l}4.3 \\
5.8\end{array}$ & $\begin{array}{l}-1.6 \\
-3.6\end{array}$ & $\begin{array}{r}2.9 \\
-1.0\end{array}$ & $\begin{array}{r}3.8 \\
-0.3\end{array}$ & $\begin{array}{l}2.7 \\
1.5\end{array}$ & $\begin{array}{l}2.5 \\
3.5\end{array}$ & $\begin{array}{l}2.8 \\
4.0\end{array}$ & $\begin{array}{r}3.9 \\
11.4\end{array}$ \\
\hline $\begin{array}{l}\text { GDP deflator } \\
\text { Excluding asricultural products }\end{array}$ & $\begin{array}{l}4.6 \\
4.2\end{array}$ & $\begin{array}{l}4.6 \\
5.1\end{array}$ & $\begin{array}{l}5.0 \\
3.8\end{array}$ & $\begin{array}{l}6.7 \\
6.4\end{array}$ & $\begin{array}{l}5.3 \\
5.1\end{array}$ & $\begin{array}{l}9.9 \\
9.5\end{array}$ & $\begin{array}{l}10.1 \\
10.5\end{array}$ & $\begin{array}{l}6.1 \\
6.5\end{array}$ & $\begin{array}{l}5.1 \\
4.7\end{array}$ & $\begin{array}{l}5.4 \\
4.8\end{array}$ & $\cdots$ \\
\hline
\end{tabular}

Sources: Bank of Korea, Hetionel docounts, Hoptbly Stetistical Bulletin; and staff estimates.

1/ Percent change over seme quarter in the provious jear, unless otherwise indicated.

2f GDP excludins value added in agriculture, forestry and fisheries, as well as governeat sector.

3/ Construction, utilities and services.

4/ Calculated as (1 - ectual outpat/potential output) * 100 for the nonfarm private sector. Potential output was estimated by soothing the los of actual output, usins a Bodrick-Prescott filter.

5/ Seasonally edjusted Iigure.

6) Difference between the actual uncmploywent rate and the trend uneuployment rate, with the latter approximating the natural rate. The trend coploywent rate was estimated by swoothing the series on the actual unemloyment rate, using a Bodrick-Prescott eilter.

If Averase hourly coupensation.

8/ Excluding africulture, forestry and fisheries, but including the government sector. Separate cuployment date are not available for the latter. Hot adjusted for cyelical variations.

9/ Construction, utilities, and private and sovernment services. 
CHART VI.1

KOREA

DEMAND, OUTPUT, COST AND PRICES, 1985-95

(Percent change over same period in the previous year)
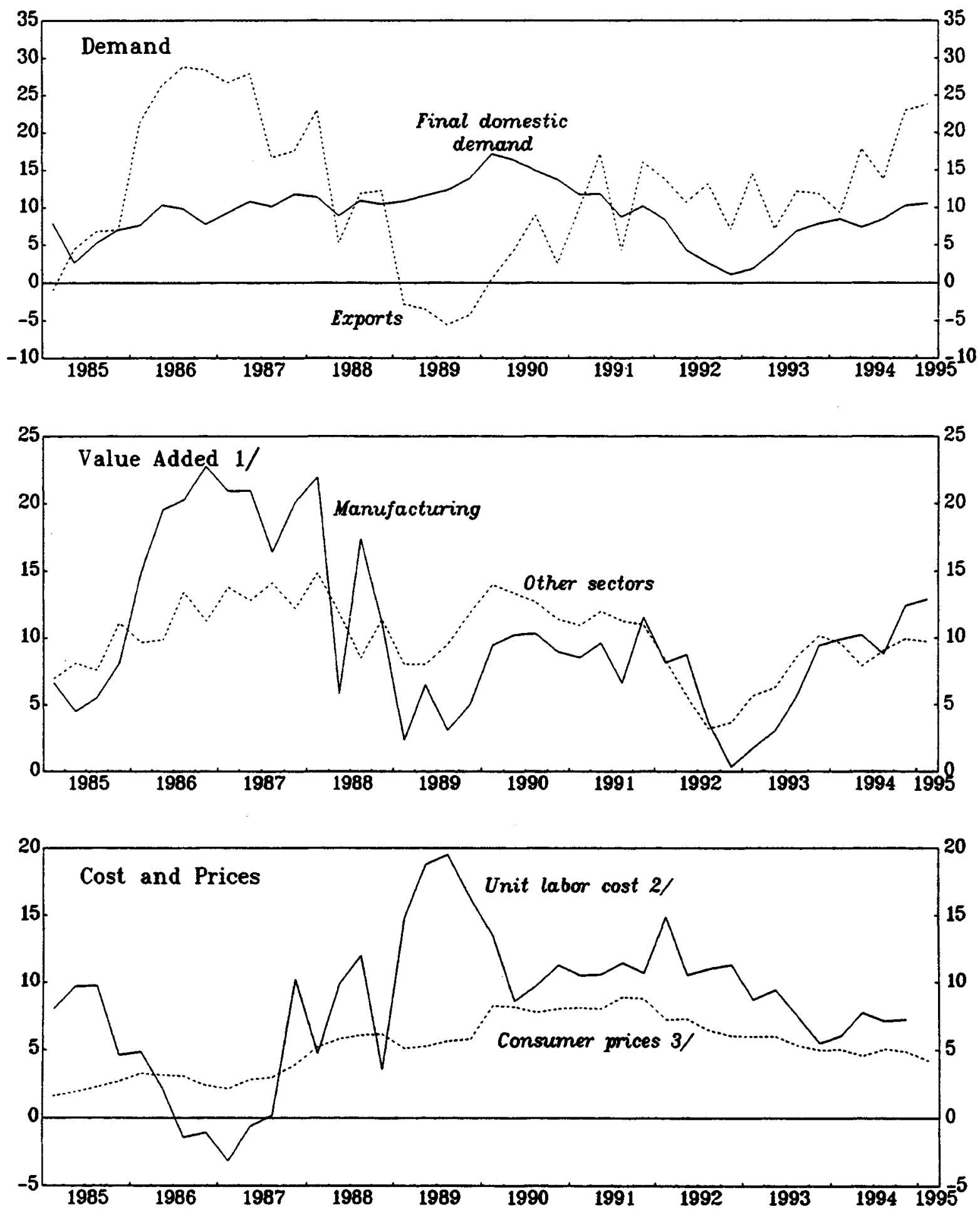

Source: Bank of Korea, Monthy Statistical Bulletin and National Accounts; and staff estimates.

1) 1990 prices.

2) Private non-farm sector.

3/ Excludine agricultural products.

CInternational Monetary Fund. Not for Redistribution 
The differences in the composition of demand in recent expansions were reflected in the sectoral composition of growth. In 1986-88, and also in the present expansion, activity in the manufacturing sector outpaced growth in the other sectors. In 1990-91, by contrast, economic activity was dominated by the construction and services sectors, with manufacturing lagging behind.

Even though the degree of resource pressure as measured by the estimated output and unemployment gaps 1 was similar in the expansions of 1986-88 and 1990-91, price developments differed significantly. In 1986-88, consumer prices remained initially subdued but picked up by nearly

2 percentage points (excluding agricultural products) in the third year of the expansion. In the 1990-91 expansion, consumer price inflation rose as soon as growth strengthened after the sharp but brief downturn in 1989. Both, in 1988 and in 1990, the acceleration of inflation reflected mainly a sharp pickup in the non-manufacturing component of the consumer price index (services and housing-related items). 2/ Manufacturing prices remained subdued during the expansion of 1986-88, followed by a relatively moderate pickup in 1989-90.

The differences in the development of manufacturing and other prices suggest that the behavior of inflation in the past two expansions was influenced by the relative strength of specific demand components and differences in pricing behavior in the sectors where demand pressures were concentrated. In addition, wage developments differed significantly. In 1986-88, constraints on wage bargaining kept wage increases initially under control. This policy resulted in a significant buildup of profits, notably in the manufacturing sector. In response, wage increases accelerated sharply in 1988, facilitated by the liberalization of wage bargaining in the context of political liberalization. Wages continued to rise rapidly in 1989, notwithstanding the sharp downturn in economic activity, and moderated only gradually from 1991 onward.

\section{The wage-price mechanism in a small open economy}

The standard model of wage and price behavior, which combines a simple Phillips curve with a markup pricing equation, $3 /$ does not distinguish between traded and nontraded goods. This distinction plays a key role in

1) See footnotes to Table VI.1 for a brief description of how these gaps were estimated.

2/ The consumer price index (excluding agricultural products) is a good indicator of overall price developments in Korea; it has moved broadly in line with the GDP deflator (excluding agriculture). The producer price index has a large import component and is thus heavily influenced by movements in import prices.

3/ See, for example, Adams and Coe (1990). 
the "Scandinavian model of inflation." 1 / Based on a number of assumptions that describe essentially long-term equilibrium relationships between the key variables, the model suggests that in a small open economy the domestic rate of inflation is determined by the rate of change of international prices for traded goods, the nominal exchange rate, and productivity growth in the traded and nontraded goods sectors. Given its focus on long-run equilibrium and the supply side, the "Scandinavian model" is not a suitable framework for an analysis of wage and price developments in the short run. Its emphasis on the distinction between traded and nontraded goods provides, however, a useful starting point for a discussion of inflation in a small open economy.

The assumptions underlying the "Scandinavian model" are (with lower case letters indicating growth rates):

$p_{t}=p_{w}+e$

$w_{t}=p_{t}+q_{t}$

$w_{n}=w_{t}$

$p_{n}=w_{n}-q_{n}$ changes in prices for domestic tradable goods $p_{t}$ are tied to changes in foreign prices $\mathrm{p}_{\mathrm{w}}$, and changes in the exchange rate e;

wage increases in the tradable goods sector $w_{t}$ follow increases in the prices of tradable goods and trend growth of labor productivity in this sector, qt, ensuring constant factor income shares;

wage increases are equalized across sectors, implying a constant relative wage between the traded and nontraded goods sectors;

prices in the nontraded goods sector $p_{n}$ are based on constant markup pricing, implying constant factor income shares.

Assumptions (1), (2) and (3) together imply that wages in the traded and nontraded goods sectors can grow at the rate of productivity growth in the traded goods sector plus the scope provided by changes in international prices of traded goods (adjusted for exchange rate changes).

The overall price index is defined as a weighted average of the price indices for traded and nontraded goods, with weights $\alpha$ and $(1-\alpha)$. Combining the above terms then yields

$p=\alpha *\left(p_{w}+e\right)+(1-\alpha) *\left(w_{n}-q_{n}\right)$

1/ This model was originally developed in the 1960 s by a group of Norwegian economists led by Odd Aukrust. The discussion in this section is mainly based on a restatement and extension of the model by Lindbeck (1979). 
which describes changes in the overall price index as a weighted average of changes in international prices of traded goods and the exchange rate, and unit labor cost in the nontraded goods sector. Simplifying (5) further to

$p=\left(p_{w}+e\right)+(1-\alpha) *\left(q_{t}-q_{n}\right)$

yields the price equation of the "Scandinavian model." Equation ( $5^{\prime}$ ) implies the well known result that a country's real exchange rate (defined in terms of the overall price index) will tend to appreciate (depreciate) relative to another country if the (positive) gap between productivity growth in the traded and nontraded goods sectors in this country is larger (smaller) than in the other country (Samuelson/Balassa effect). I/

The main merit of the "Scandinavian model" is that it highlights the long-run structural determinants of inflation in a small open economy.

Even though it focusses on the real side and does not explicitly incorporate monetary factors, it implicitly allows for monetary policy effects on inflation through the exchange rate. $2 /$ However, while the model provides a useful framework for the analysis of inflation in the long run, particularly if it is extended to incorporate monetary factors, it is not well suited for an analysis of wage and price developments in the short run. In the short run, factor income shares can vary, wages in the tradable and nontradable goods sectors may deviate, and demand conditions, in both goods and labor markets, matter. 3/ The remainder of this section thus focusses on the modifications of the wage and price equations that are needed to allow for demand effects in the short and medium run. The critical

1) Defining (5') for two countries $c_{1}$ and $c_{2}$, assuming $\alpha_{1}=\alpha_{2}=\alpha$, and subtracting the two equations yields

$$
e_{21}-\left(p_{2}-p_{1}\right)-(1-\alpha) *\left(\left(q_{1 t}-q_{1 n}\right)-\left(q_{2 t}-q_{2 n}\right)\right)
$$

with $e_{21}=e_{2}-e_{1}$ denoting the change in the bilateral nominal exchange rate between the two countries.

2/ While in a fixed exchange rate system, domestic inflation is fully determined by $\left(5^{\prime}\right)$ and monetary disequilibrium is reflected in the balance of payments, under flexible exchange rates monetary policy can influence domestic inflation. The "Scandinavian model" does not incorporate this aspect of the adjustment mechanism but it can be extended to include it. In fact, equation $\left(5^{\circ}\right)$ can be considered a modification of the standard PPP assumption underlying the monetary approach to the balance of payments.

3 The neglect of the demand side in the "Scandinavian model" has been widely criticized whenever it was used to analyze wage and price developments in the short run (see, for example, the comments on the paper by Aukrust in Krause and Salant (1977)). The assumptions that are required to ensure that price developments are independent of demand factors within a simple general equilibrium framework are discussed in Kierzkowski (1976). De Gregorio et al. (1994), and Gordon (1994) propose alternative assumptions to obtain this result. 
distinction between price behavior in the tradable and nontradable goods sectors is retained, and it is shown that the essential long-term results of the "Scandinavian model" continue to hold.

As a first step, it is convenient to retain the original price equations of the model and assume that wage determination is adequately described by a standard Phillips curve $1 /$

$w=\beta_{0}-\beta_{1} * u+p^{e}$

with $p^{e}$ indicating expected inflation, $u$ the unemployment rate, and $w-w_{t}=w_{n}$. Equation (6) can be solved for the unemployment rate $u_{\text {nat }}$ that is consistent with real wages in the traded and nontraded goods sectors growing at the same rate as labor productivity in each sector, implying constant factor income shares $2 /$

$u_{\text {nat }}=\left(1 / \beta_{1}\right) *\left(\beta_{0}-\left(\alpha * q_{t}+(1-\alpha) * q_{n}\right)\right.$

Equation (7) does not differ from the standard formulation for a closed economy, $3 /$ except that labor productivity growth is expressed as a weighted average of productivity growth in the traded and nontraded goods sectors. Using (7) to incorporate unat explicitly in the Phillips curve equation yields

$w=-\beta_{1} *\left(U-U_{n a t}\right)+p^{e}+\left(\alpha * q_{t}+(1-\alpha) * q_{n}\right)$

In the short run, wage developments are affected by labor market conditions, but in the long run, with $U=U_{\text {nat, }}$ and $p^{e}=p$, assumptions (2) and (4) of the "Scandinavian model" hold.

While long-run equilibrium requires equalization of wages in the traded and nontraded goods sectors, 4/ labor market rigidities may cause temporary deviations. For example, if due to labor market conditions, errors in price expectations, or temporary disturbances wage developments deviate from their long-term equilibrium path, profit margins and factor income shares in the traded goods sector change since prices are constrained by developments in international prices and the exchange rate. 5 / Eventually, such changes would be corrected through their impact on labor

1 The inclusion of a Phillips curve is, in fact, sufficient to introduce demand effects.

2/ Expected inflation is assumed to be equal to actual inflation and no distinction is made between consumer prices and product prices.

3/ See Adams and Coe (1990).

4/ Permanent deviations between wage developments in the traded and nontraded goods sectors would require fully and permanently segmented labor markets.

5/ By contrast, in the nontraded goods sector wage increases are passed on to prices and income shares remain unchanged. 
demand in the traded goods sector. It is possible, however, that employers and employees take changes in income shares into account in the process of wage bargaining so that

$w=-\beta_{1} *\left(U-U_{n a t}\right)+p^{e}+\left(\alpha * q_{t}+(1-\alpha) * q_{n}\right)-\beta_{2} * Z$

with $Z$ indicating past deviations from the long-term income share of labor. Since in equilibrium $\mathrm{Z}=0$, equation $\left(6^{\prime \prime}\right)$ retains the long-run properties of the original model, but includes an adjustment mechanism that limits deviations from long-run income shares, which otherwise would only be corrected through their impact on employment. I/ Evidently, such a bargaining strategy is only feasible if there are rigidities in the labor market that permit temporary deviations in wage developments in the traded and nontraded goods sector. Labor market and wage developments in Korea suggest that such rigidities exist and that they are taken into account in the decentralized wage bargaining process (see next section).

The price equations of the "Scandinavian model" assume complete price taking behavior in the traded goods sector. While this may be a reasonable approximation to describe the pricing behavior of Korean exporters in foreign markets, 2 / it appears too rigid an assumption for the traded goods sector as a whole. Given the structure of Korean imports, which suggests relatively limited import competition, $\underline{3} /$ and the possibility of price discrimination between foreign and domestic markets by Korean exporters, 4/ the prices of tradable goods that are sold domestically may only depend to a limited degree on changes in foreign prices and the exchange rate, and to a significant degree on domestic cost and demand factors, the latter being approximated by the output gap $\left(Y-Y_{p}\right)$

$p_{t d}=\delta_{1} *\left(p_{w}+e\right)+\delta_{2} *\left(Y-Y_{p}\right)+\left(w_{t}-q_{t}\right)$

Similarly, equation (4) can be modified to allow for a variable markup

1) Equation (6\%) is, of course, similar to a standard error corrections formulation.

2/ Athukorala's (1991) study on exchange rate pass-through suggests that Korean exporters are largely price takers and try to keep their prices in line with those of foreign competitors.

3/ Some 90 percent of Korean imports are intermediate and capital goods for which there are generally no close domestic substitutes. While imports of consumer goods have increased significantly, they still account for a relatively small share of imports.

4/ For a simple model of price discrimination in domestic and foreign markets see, for example, Aspe and Giavazzi (1982) and Ohno (1989). While models of price discrimination generally assume imperfect competition in all markets, the assumption of perfect competition in the foreign market and imperfect competition in the domestic market can be considered a special case of the more general model. 


$$
P_{n}=\gamma_{1} *\left(Y-Y_{P}\right)+\left(w_{n}-q_{n}\right) \quad\left(4^{\prime}\right)
$$

The price index for all traded goods is a weighted average of $p t d$, the goods sold domestically, and $P_{t w}$, the goods sold abroad 1

$\mathrm{P}_{t}=\theta_{1} *\left(\mathrm{p}_{\mathrm{w}}+\mathrm{e}\right)+\theta_{2} *\left(\mathrm{Y}-\mathrm{Y}_{\mathrm{p}}\right)+\theta_{3} *\left(w_{t}-\mathrm{q}_{t}\right)$

with $\theta_{1} \ldots \theta_{4}$ depending on the relative weights of $p_{t d}$ and $p_{t w}$ as well as the coefficients of equation ( 8 ).

Equation ( $1^{\prime}$ ) is sufficiently general to accommodate less than complete price taking behavior on the part of exporters. This would be reflected in a smaller coefficient of the foreign price and exchange rate variables and a larger coefficient of the cost variable, which does not have to be, however, equal to one. It is worth noting that as long as exporters are assumed to be complete price takers and domestic prices in the traded goods sector are independent of foreign prices $\left(\delta_{1}=0\right)$, the proposition of the "Scandinavian model" concerning the equilibrium path of wages and the long-run determinants of overall inflation (5') still hold. If these assumptions are replaced by a more general price equation as described by ( $\left.I^{\prime}\right)$, the influence of foreign prices (and the exchange rate) on overall inflation and the equilibrium path of wages in the long run depends on the coefficients of the price equation for the traded goods sector as a whole. $2 /$

Equations $\left(6^{\prime}\right),\left(4^{\prime}\right)$, and $\left(1^{\prime}\right)$ describe a simple framework for the analysis of wage and price developments in Korea. Given the differences in pricing behavior in the traded and nontraded goods sectors, the variable capturing demand pressures $\left(Y-Y_{p}\right.$ ) should reflect domestic rather than total demand. Moreover, the larger is the share of goods sold abroad and the more prevalent is price taking behavior in the tradables sector, the smaller will be the effect of demand and wage pressures on prices in this sector. 3/ Under these conditions, an expansion that is characterized by strong foreign demand and, at least initially, subdued domestic demand can indeed be expected to result in more moderate price pressures than an expansion led by domestic demand, particularly if labor intensity in the

1/ The price indices are defined as value added deflators and therefore ignore the direct impact of import prices.

2f The unemployment rate unat that is consistent with the equilibrium path of wages and, hence, constant factor income shares, is independent of the specification of the price equations as long as price expectations focus on overall inflation rather than domestic prices alone. If the latter dominate and domestic prices in the traded goods sector are influenced by foreign prices, unat will be a positive function of the rate of increase of foreign prices converted into national currency.

3) The traded goods sector does, of course, respond to wage pressures, but changes in employment or a wage bargaining process that takes into account changes in factor income shares (as described by equation (6'")) may play a more important role than price adjustments. 
traded goods sector is lower than in the nontraded goods sector, and if there are short-term rigidities in the labor market that permit temporary deviations in wage developments in both sectors.

\section{Wage and price determination in Korea: some stylized facts}

The framework developed in the previous section combines the key elements of the "Scandinavian model," (the distinction between traded and nontraded goods, and assumptions about differences in pricing behavior in the two sectors) with the standard Phillips curve approach. A key question is whether such a framework captures the main stylized facts of the process of wage and price determination in Korea.

Price developments in the traded and nontraded goods sectors since 1983 are summarized in Chart VI.2. They suggest that pricing behavior in both sectors differed indeed significantly. While the "nontraded goods" component of the consumer price index (services and housing cost) appears to have followed relatively closely cyclical developments, the "traded" goods component (manufacturing goods) appears to have been affected relatively little by domestic demand conditions. This does not, however, imply that domestic prices in the traded goods sector have mainly been influenced by foreign price developments as the "Scandinavian model" assumes.

Developments in the manufacturing component of the consumer price index have, in fact, deviated considerably from developments in export prices. Although this may, to some extent, reflect differences in the coverage and weights of the two indices, it nevertheless suggests that price discrimination between foreign and domestic markets may play a role.

A notable feature of price developments in the traded goods sector is that Korean export prices in terms of U.S. dollars appear to have followed, albeit with a lag of several quarters, the export prices of major competitor countries. This observation is borne out by a regression of changes in the dollar prices of Korean exports on past changes in competitor prices. 1 This could be interpreted as evidence that Korean exporters are indeed price takers in foreign markets and adjust their won prices in line with movements in foreign prices and the exchange rate. However, the close relationship between changes in dollar export prices and past changes in foreign prices may also reflect the response of exchange rate policy. A regression of changes in the won/dollar exchange rate on past changes in competitor prices

1) A regression of annual percentage changes in Korean export prices in terms of U.S. dollars, px\$, on a weighted average of export unit values of major competitor countries, pw\$, yields ( $t$-values are indicated in parentheses):

$$
\operatorname{px} \$=\underset{(2.73)}{0.21 * p w \$}+\underset{(9.62)}{0.84 * p \times \$[-1]} \quad \text { R2: } 0.92 \quad \text { D.W.: } 2.11
$$


suggests that this is indeed the case in Korea, $1 /$ and that changes in export prices in terms of won account for a relatively small part of the adjustment.

Wage and productivity developments in Korea since 1983 are summarized in Chart VI.3. They indicate that wages in the traded and the nontraded goods sectors have generally moved closely together, and that productivity growth has tended to be higher in the traded than in the nontraded goods sector, two key assumptions underlying the "Scandinavian model." However, during 1987-90, wages in the traded goods sector outpaced wage increases in the nontraded goods sector by a significant margin, resulting in a marked upward shift in the previously (and subsequently) relatively stable relative wage between the two sectors (Chart VI.4). This shift occurred during the period of "wage explosion," which appears to have been a response to the preceding redistribution of factor incomes in favor of profits, as indicated by the development in factor income shares. This redistribution, and the subsequent response, appears to have been considerably more pronounced in the traded goods sector than in the nontraded goods sector.

\section{Econometric analysis of wage and price behavior}

Based on the framework developed in section 3, wage and price equations were estimated for the traded and nontraded goods sectors. As in the preceding sections, the former is broadly identified with the manufacturing sector, while the latter comprises all other sectors, with the exception of agriculture and government.

The wage equations were specified so as to capture the special features of the Korean wage system. Total earnings consist of a basic wage, which accounts on average for some 70 percent of total monthly earnings and is determined in annual wage negotiations, generally at company level. In addition, employees receive overtime and special bonus payments. Although trade unions have increasingly sought to include bonus payments in annual, wage contracts, they remain a relatively flexible element of the wage system, depending mainly current labor market conditions and productivity developments.

Given the two main components of total earnings, the wage equations reflect the factors that are expected to influence the annual wage negotiations, which determine the base wage for the following year, as well as factors that affect additional payments during the year. Current labor market conditions, reflected in the difference between the actual and the trend unemployment rate, $U_{g a p}$, and current productivity growth $q$ are

1 The regression results are (all variables in terms of year-on year changes; $t$-values in parentheses):
$e=0.21 *$ pw\$ $+0.87 * e[-1]$
$(2.68)$
(9.64)
R2: $0.95 \quad$ D.W.: 1.97 
CHART VI.2

KOREA

(Percent change over same period in the previous year)
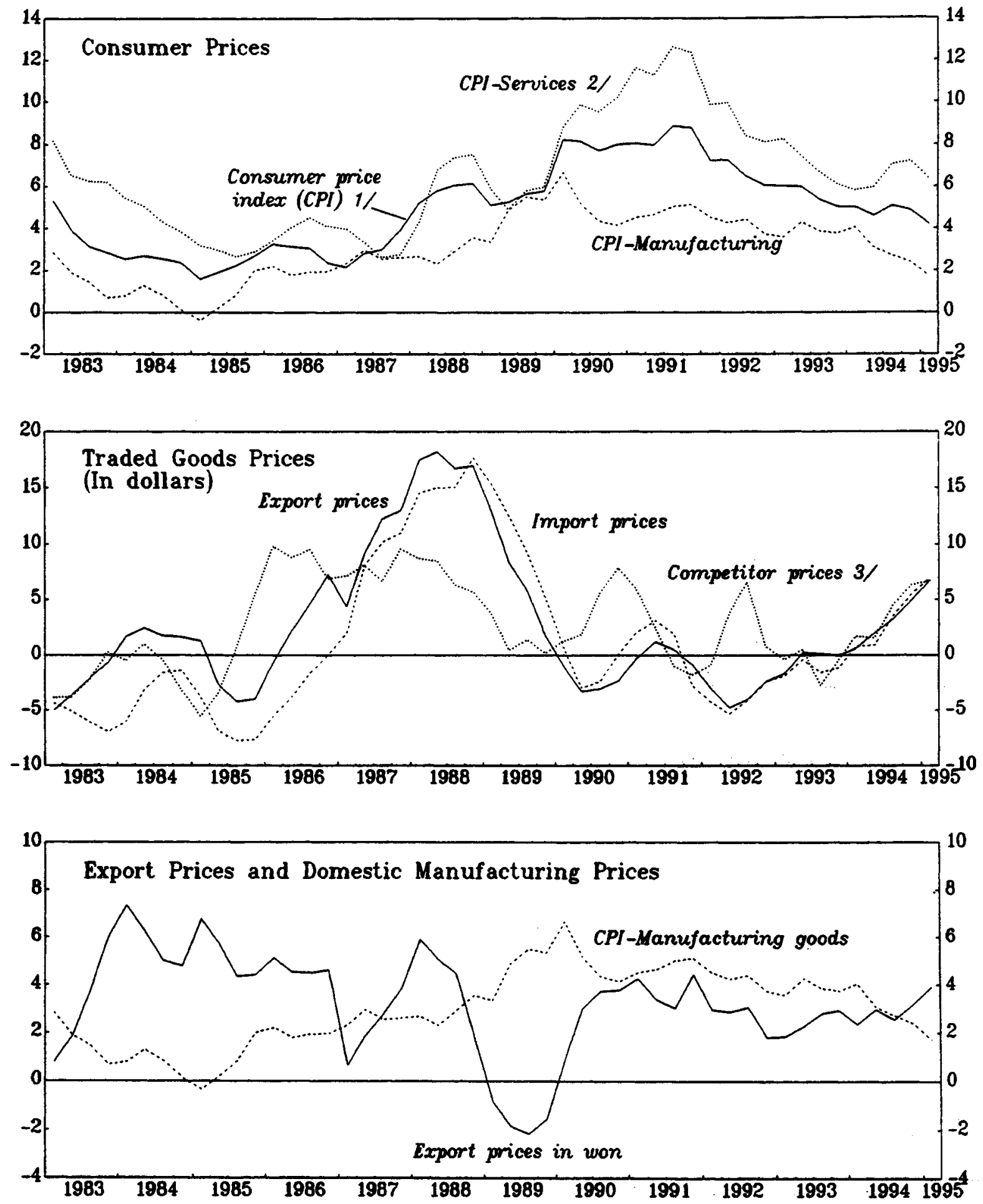

Source: Bank of Korea, Monthly Statistical Bulletin; and staff estimates.

1/ Ercluding agricultural products.

2) Including housing and utilities.

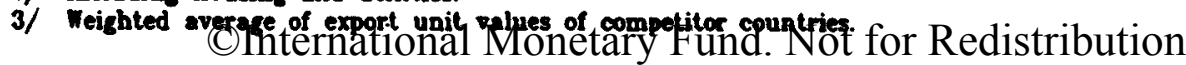


CHART V1.3

KORPA

WAGES AND PRODUCTIVITY, 1983-95

(Percent change over same period in the previous year)
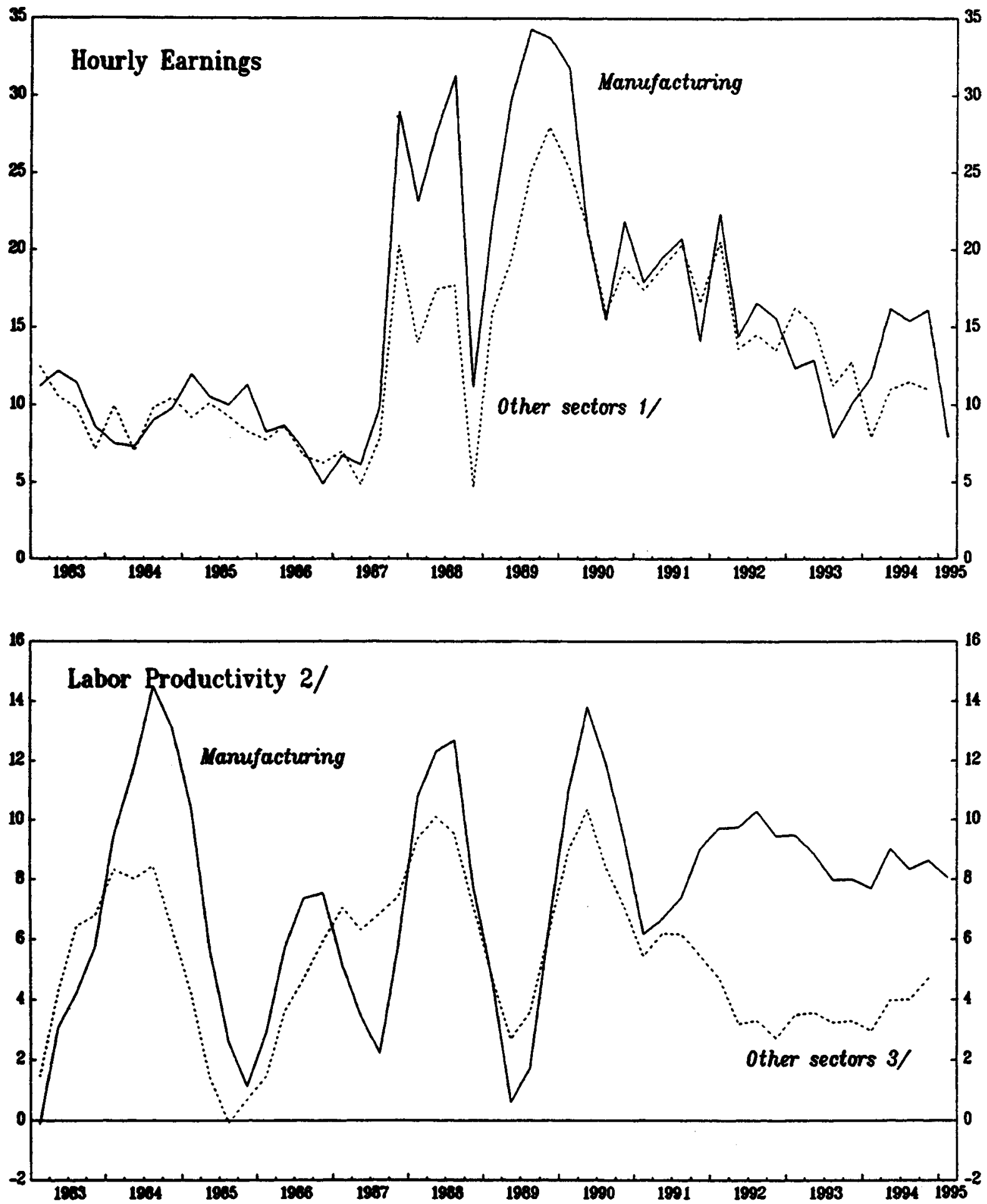

Source: Bank of Korea, Yonthl Statistical Bulletin; Ministry of Labor, Yearbook of Labor Statistics; and staff entimates.

$1 /$ Excludiag agriculture and governmeot.

2) Tour quarter moving average of seay-on-year chapse in output per man hour.

s/ Excludias fidinternational Monetary Fund. Not for Redistribution 
CHART VI.4

KOREA

RELATIVE WAGES AND FACTOR INCOME SHARES, 1970-94
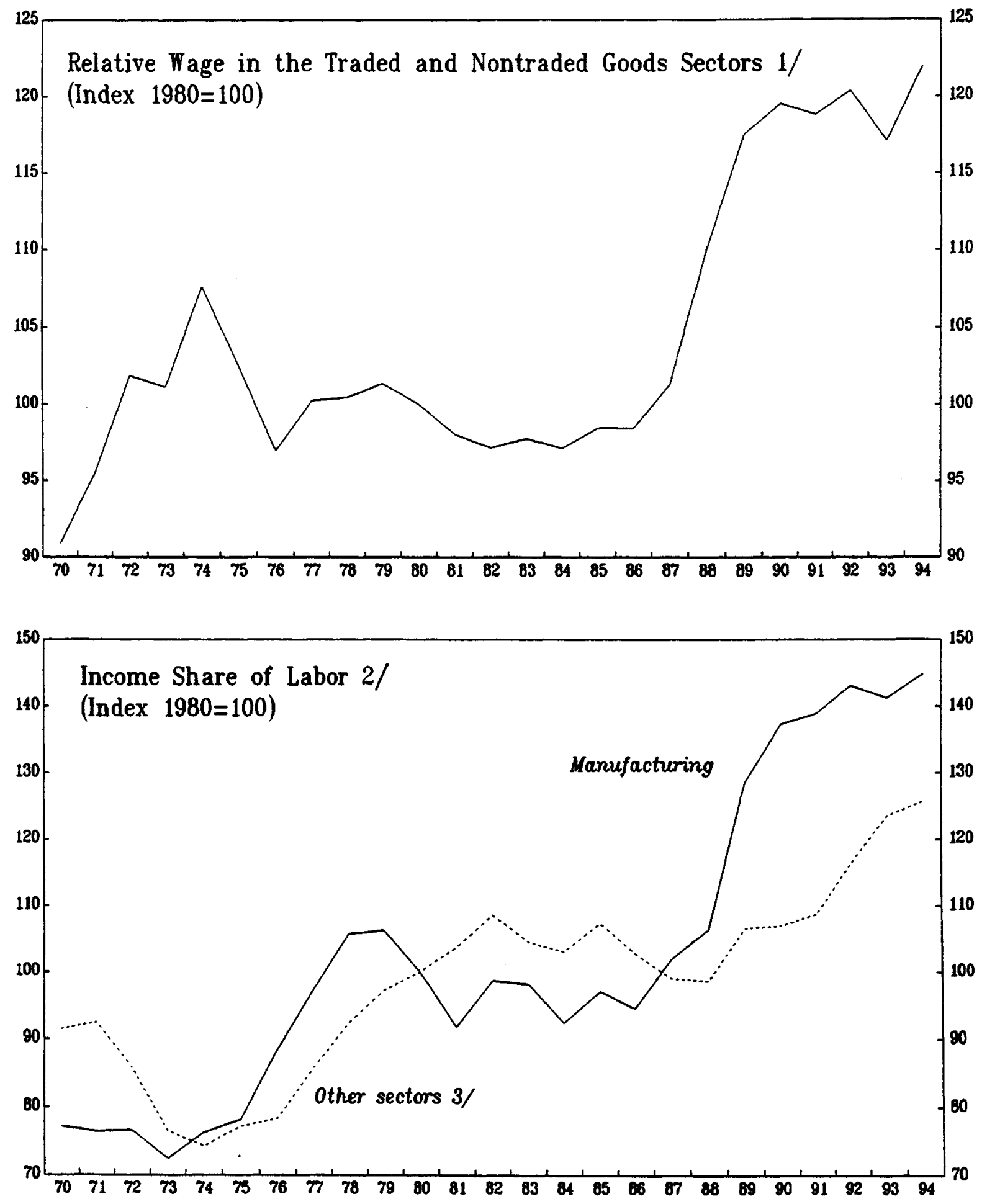

Source: Bank of Korea, National Accounts, Ministry of Labor, Yearbook of labor Stalistics; and staff estimates.

1/ Hourly earning in manufacturing relative to other sectors (ercluding agriculture and government). 
expected to influence bonus payments, while labor market conditions, productivity developments, and inflation expectations $p^{e}$ at the time of the last wage round are expected to determine developments in the base wage. Efforts to correct past deviations in factor income shares, captured by the variable $Z$, are assumed to play a role mainly in annual wage negotiations, while sectoral differences in labor market conditions, approximated by the difference between employment growth in the manufacturing and nonmanufacturing sectors, are expected to affect bonus payments. 1 /

The estimation results for the wage equations are summarized in Table VI.2. The results suggest that the framework developed in section 3 fits the data quite well, both in the manufacturing and the other sectors. All coefficients, with the exception of the variable approximating price expectations, are significant and have the expected signs. As predicted by the model, the sum of the coefficients of the productivity variables is close to unity in most equations. The large coefficients of the unemployment variable, Ugap, can be attributed to the fact that due to cyclical variations in labor force participation, the unemployment rate in Korea varies relatively little over the cycle. Differences between the actual unemployment rate and the trend unemployment rate have typically ranged between $1 / 4$ and $1 / 2$ of one percentage point in recent years.

The estimation results indicate a few notable differences between the process of wage determination in the manufacturing sector and the other sectors. While overall labor market conditions appear to have a strong impact on both wage negotiations and bonus payments in the manufacturing sector, they seem to influence only the wage bargaining process in the other sectors (services, utilities, and construction). In these sectors, current wage payments appear to be affected by sectoral differences in labor market conditions, with faster growth in manufacturing employment relative to other sectors exerting a moderating influence.

The most important difference between wage behavior in the manufacturing sector and the other sectors concerns the role of shifts in factor income shares. Efforts to correct past deviations from trend income shares appear to have been an important factor in the wage bargaining process in the manufacturing sector, and, indeed, seem to explain much of the "wage explosion" in the late 1980s. However, following a sharp rise in the income share of labor in 1988-89, this feature of the wage process appears to have contributed to the steady moderation of wage increases in subsequent years, notwithstanding tight labor market conditions. In other sectors, the shift in factor income shares in the mid 1980s was much less pronounced, and, consequently, did not have a significant impact on wage developments.

1) See note to Table VI.2 for a detailed description of the variables. 
Table VI.2. Koreá: Wage Equations

\begin{tabular}{|c|c|c|c|c|c|c|}
\hline \multirow[t]{2}{*}{$\begin{array}{c}\text { Explanatory } \\
\text { Variables }\end{array}$} & \multicolumn{3}{|c|}{$\begin{array}{c}\text { Manufacturing } \\
\text { Sector }\end{array}$} & \multicolumn{3}{|c|}{$\begin{array}{l}\text { Other } \\
\text { Sectors } 1 /\end{array}$} \\
\hline & (1) & (2) & (3) & (1) & (2) & (3) \\
\hline Constant & $\begin{array}{l}16.81 \\
(5.66)\end{array}$ & $\begin{array}{l}12.47 \\
(4.43)\end{array}$ & $\begin{array}{l}11.46 \\
(3.64)\end{array}$ & $\begin{array}{c}6.82 \\
(2.38)\end{array}$ & $\begin{array}{c}6.03 \\
(2.09)\end{array}$ & $\begin{array}{c}5.24 \\
(2.08)\end{array}$ \\
\hline $\mathrm{v}_{\text {gap }}$ & $\begin{array}{l}-9.11 \\
(5.38)\end{array}$ & $\begin{array}{l}-7.63 \\
(5.05)\end{array}$ & $\begin{array}{l}-6.85 \\
(3.69)\end{array}$ & $\begin{array}{c}0.37 \\
(0.20)\end{array}$ & $\begin{array}{c}0.04 \\
(0.02)\end{array}$ & $\begin{array}{l}-0.24 \\
(0.16)\end{array}$ \\
\hline $\mathrm{U}_{\text {gap }}(-4)$ & $\begin{array}{r}-11.89 \\
(4.70)\end{array}$ & $\begin{array}{l}-9.37 \\
(4.11)\end{array}$ & $\begin{array}{r}-10.60 \\
(3.72)\end{array}$ & $\begin{array}{l}-7.85 \\
(4.21)\end{array}$ & $\begin{array}{l}-6.11 \\
(2.73)\end{array}$ & $\begin{array}{l}-3.84 \\
(1.87)\end{array}$ \\
\hline $\mathbf{q}$ & $\begin{array}{c}0.47 \\
(3.01)\end{array}$ & $\begin{array}{c}0.43 \\
(3.20)\end{array}$ & $\begin{array}{c}0.53 \\
(2.81)\end{array}$ & $\begin{array}{c}0.62 \\
(3.54)\end{array}$ & $\begin{array}{c}0.66 \\
(3.77)\end{array}$ & $\begin{array}{c}0.89 \\
(5.35)\end{array}$ \\
\hline$q^{\operatorname{tr}}(-4)$ & $\begin{array}{c}0.50 \\
(2.43)\end{array}$ & $\begin{array}{c}0.39 \\
(2.14)\end{array}$ & $\begin{array}{c}0.43 \\
(2.24)\end{array}$ & $\begin{array}{c}0.41 \\
(2.08)\end{array}$ & $\begin{array}{c}0.31 \\
(1.54)\end{array}$ & $\begin{array}{c}0.38 \\
(2.12)\end{array}$ \\
\hline$p^{e}(-4)$ & $\begin{array}{l}-1.65 \\
(4.06)\end{array}$ & $\begin{array}{l}-0.56 \\
(1.22)\end{array}$ & $\begin{array}{l}-0.51 \\
(1.08)\end{array}$ & $\begin{array}{c}0.44 \\
(1.28)\end{array}$ & $\begin{array}{c}0.61 \\
(1.68)\end{array}$ & $\begin{array}{c}0.33 \\
(1.03)\end{array}$ \\
\hline$z(-4)$ & .. & $\begin{array}{c}1.28 \\
(3.71)\end{array}$ & $\begin{array}{c}1.29 \\
(3.71)\end{array}$ & $\ldots$ & $\begin{array}{c}0.48 \\
(1.37)\end{array}$ & $\begin{array}{c}0.31 \\
(1.00)\end{array}$ \\
\hline le & $\ldots$ & $\ldots$ & $\begin{array}{c}0.12 \\
(0.73)\end{array}$ & $\ldots$ & $\cdots$ & $\begin{array}{l}-0.35 \\
(3.53)\end{array}$ \\
\hline $\mathbf{R}^{2}$ & 0.72 & 0.79 & 0.79 & 0.71 & 0.72 & 0.79 \\
\hline DW & 1.79 & 2.14 & 2.07 & 1.64 & 1.66 & 1.97 \\
\hline $\boldsymbol{F}$ & 22.27 & 27.26 & 23.13 & 21.94 & 19.02 & 23.29 \\
\hline
\end{tabular}

Source: Stafe estimates.

1f Erivate nonface sector, excludins manufacturing.

Hote: The dependent variables are the srowth rates of average hourly earainss in the menufacturins sector (traded sood soctor) and In all othax sectors, excludins asriculture and goverpeent (nontraded goods sector). All growth rates are defined as the fourth difference of the 108 of the series anltiplied by 100 . The equations were estimates by OLS for the period $1984 Q 2$ to 1994Q4. $t$ values are shown in parentheses below the coefficients.

The explanatory variables are defined as follows: $U_{\text {gap }}$ is the difference botween the unemplognent rate and an approximation of the natural rate, derived by applyins a Hodrick-Prescott filter to the original

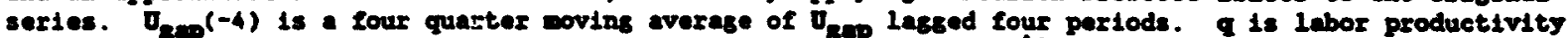
srowth in the respective sectors. dofined as output par wen hour. $q^{\text {tr }}(-4)$ is the trend growth of 1 abor productivity lessed lour guarters, derivod by applying a Bodrick-Prescott ellter to the origlnal series. $p^{\circ}(-4)$ is a four quarter woving everage of the rate of consumer price inflation, lasged four periods. $z$ is a four guarter novins everase of the difference between the actual incowe shaxe of copltal and the trend share, derived by applyins a Bodrtek-Prescott filter to the orisinal series. Io is the difference between the growth rate of coplopment in the menufecturins sector and in all other soctors.

CInternational Monetary Fund. Not for Redistribution 
Estimation results for the price equations are summarized in Table VI.3. Since quarterly data on value added deflators are not available, prices in the traded and nontraded goods sectors were approximated by the manufacturing and the services $1 /$ components of the consumer price index. $2 /$ A notable feature of the price equations is that the coefficients of the unit labor cost variables, while significant in all equations, are well below unity, suggesting that only a part of the cost increases were passed on to prices. While such pricing behavior would not be sustainable in the long run, it is the mirror image of the large shifts in factor income shares in the past ten years, which went far beyond the usual cyclical variations in income shares and are therefore not captured in the cyclical variables. $\underline{3} /$

The estimation results suggest that price behavior in the manufacturing sector (traded goods sector) differ from that in other sectors (nontraded goods sector) in several respects. Prices in the nontraded goods sector not only respond more strongly to increases in unit labor cost than domestic prices of manufacturing goods, they also react more strongly to domestic demand conditions, approximated by the output gap in the non-manufacturing sectors. 4/ While a positive output gap of one percentage point adds nearly as much to the non-manufacturing component of consumer price inflation, an increase in the positive output gap by the same amount would raise the manufacturing component by less than one $1 / 2$ of one percentage point.

In contrast to the assumptions underlying the "Scandinavian model," there is no evidence of a significant impact of foreign price developments on domestic manufacturing goods prices. Neither changes in foreign competitor prices nor import prices are significant in the price equations. While the latter reflects a relatively low degree of import penetration in the consumer goods sector, the former could be interpreted as evidence of price discrimination on the part of Korean manufacturers between foreign and domestic markets. However, clarification of this issue would require an analysis of the pricing behavior of Korean exporters, which is beyond the scope of this study.

1) Including housing cost and utilities.

2/ While the producer price index covers mainly manufacturing goods, it has a large import content and is therefore not a good indicator of domestic prices.

3/ While the wage equations include a variable that captures this effect, the price equations do not, and the coefficients of other variables may reflect part of the effect.

4/ In order to capture sector-specific demand pressures, the output gap in the manufacturing sector was included in the price equations. However, domestic manufacturing prices appear to be related to domestic demand pressures for which the output gap in the non-manufacturing sectors seems to be a better proxy. 
Table VI.3. Korea: Price Equations

\begin{tabular}{|c|c|c|c|c|c|c|c|}
\hline \multirow[t]{2}{*}{$\begin{array}{l}\text { Explanatory } \\
\text { variables }\end{array}$} & \multicolumn{4}{|c|}{$\begin{array}{l}\text { Manufacturing } \\
\text { goods }\end{array}$} & \multicolumn{3}{|c|}{$\begin{array}{l}\text { Other goods } \\
\text { and services }\end{array}$} \\
\hline & (1) & (2) & (3) & (4) & (1) & (2) & (3) \\
\hline Constant & $\begin{array}{c}1.74 \\
(2.24)\end{array}$ & $\begin{array}{c}1.98 \\
(2.49)\end{array}$ & $\begin{array}{c}1.86 \\
(2.28)\end{array}$ & $\begin{array}{c}1.98 \\
(2.41)\end{array}$ & $\begin{array}{c}3.51 \\
(8.53)\end{array}$ & $\begin{array}{c}3.53 \\
(7.80)\end{array}$ & $\begin{array}{c}3.30 \\
(6.92)\end{array}$ \\
\hline$Y_{\text {gap }}$ & $\begin{array}{l}-0.04 \\
(0.29)\end{array}$ & $\begin{array}{l}-0.10 \\
(0.70)\end{array}$ & $\begin{array}{l}-0.11 \\
(0.76)\end{array}$ & $\begin{array}{l}-0.10 \\
(0.72)\end{array}$ & $\begin{array}{c}0.86 \\
(7.84)\end{array}$ & $\begin{array}{c}0.85 \\
(6.94)\end{array}$ & $\begin{array}{c}0.85 \\
(7.40)\end{array}$ \\
\hline$\Delta Y_{\text {gap }}$ & $\cdots$ & $\begin{array}{c}0.43 \\
(2.09)\end{array}$ & $\begin{array}{c}0.42 \\
(2.08)\end{array}$ & $\begin{array}{c}0.43 \\
(2.09)\end{array}$ & $\cdots$ & $\begin{array}{l}-0.01 \\
(0.04)\end{array}$ & $\begin{array}{c}0.01 \\
(0.06)\end{array}$ \\
\hline$\left(w-q^{t r}\right)$ & $\begin{array}{c}0.19 \\
(2.90)\end{array}$ & $\begin{array}{c}0.19 \\
(3.09)\end{array}$ & $\begin{array}{c}0.20 \\
(3.20)\end{array}$ & $\begin{array}{c}0.19 \\
(2.95)\end{array}$ & $\begin{array}{c}0.36 \\
(7.50)\end{array}$ & $\begin{array}{c}0.36 \\
(6.84)\end{array}$ & $\begin{array}{c}0.38 \\
(7.18)\end{array}$ \\
\hline $\mathbf{P}_{\mathbf{m}}$ & $\cdots$ & $\cdots$ & $\begin{array}{c}0.03 \\
(0.78)\end{array}$ & $\cdots$ & $\cdots$ & $\cdots$ & $\begin{array}{c}0.05 \\
(0.94)\end{array}$ \\
\hline$\left(p_{w}+e\right)$ & $\cdots$ & $\cdots$ & $\ldots$ & $\begin{array}{c}0.01 \\
(0.35)\end{array}$ & $\cdots$ & $\cdots$ & $\cdots$ \\
\hline $\mathbf{R}^{2}$ & 0.88 & 0.89 & 0.89 & 0.89 & 0.92 & 0.92 & 0.92 \\
\hline DW & 1.72 & 1.84 & 1.83 & 1.81 & 1.43 & 1.49 & 1.51 \\
\hline $\mathbf{F}$ & 109.22 & 93.77 & 74.44 & 73.43 & 179.64 & 131.26 & 104.74 \\
\hline$P$ & 0.88 & 0.88 & 0.88 & 0.88 & 0.52 & 0.56 & 0.52 \\
\hline
\end{tabular}

Source: Staff estimates.

Note: The dependent variables are the rates of increase of the manufacturins and the services (includins utilities and housins) components of the consumer price index. All growth rates are defined as the fourth difference of the 108 of the series anitiplied by 100 . The equetions were estimated for the period 1983QI-19940IV using the Cochrane-Orcutt procedure to correct for serial correlation in the residuals. The estinated first order mutocorrelation coefficients of the residuals are indicated in the lest row of the table. t values are indicated in parentheses below the coefficients.

The explenatory varibbles are defined as follows: $Y_{\mathrm{gap}}$ is the difference between actual and potentiel output in the private nonfarm sector (excludins manufacturins) in percent of potential output. Potential output was estimated by smoothing the 108 of ectual output, using a Blodrick-Prescott filter. Ar gap is the first difference of $\mathrm{Y}_{\mathrm{gap}}$. (w - q th) indicates an eight quarter movins average of changes in unit labor costs in the menufecturing and nowmufacturing (excluding agriculture and government) sectors, respectively. Chenges in unit lebor costs are defined as the difference between the erowth of average hourly earnines and the growth of output per man hour averaged over four guarters (trend productivity growth) in each sector. $P$ is a four quarter moving average of import price increases. (Pw $+e$ ) is a four cuarter woving arerage of chmses in coupetitor prices (in U.S. dollars) and the won/dollar exchange rate. Coupetitor prices are calculated as a weighted average of export unit values of major compotitor countries using export-based weights. 


\section{Conclusions}

Price developments in recent expansions in Korea have differed significantly. While resource pressures, as measured by overall output gaps, have been broadly similar, the expansions have differed in terms of their structure (the relative contributions to growth of the traded and nontraded goods sectors), and wage developments. In order to assess the importance of differences in the composition of demand as well as special factors influencing wage behavior, a simple theoretical framework for the analysis of wage and price behavior in a small open economy was developed. The framework combines key elements of the "Scandinavian model of inflation," notably assumptions about differences in pricing behavior in the traded and nontraded goods sectors, with a standard Phillips curve approach.

Although the results of the econometric analysis of wage and price developments do not fully agree with the predictions of the model, they are consistent with the view that price, and to a lesser extent wage, behavior in the traded (manufacturing) and nontraded (other) goods sectors differ. In particular, the impact on prices of cost and demand pressures is much stronger in the nontraded goods sector than in the traded goods sector. Thus, even though in the late 1980s wage and unit labor cost increases in the manufacturing (traded goods) sector exceeded those in other sectors, increases in domestic prices of manufacturing goods were more moderate than price increases in other sectors. The resulting shift in factor income shares in favor of labor income was in large part a correction of the redistribution in favor of profits that had occurred in the preceding years.

Given the large shifts in relative income shares during the estimation period, caution seems warranted in drawing general conclusions from the estimated parameters of the price equations. Nevertheless, to the extent that they suggest a stronger response to cost and demand pressures in the nontraded than in the traded goods sector, they imply that, at least in the short run, the composition of demand matters for the behavior of inflation in an expansion. Ultimately every expansion, irrespective of its origin, will lead to price pressures as it affects labor market and domestic demand conditions. However, an expansion that is initially concentrated in the traded goods sector is likely to be associated with more moderate inflation than an expansion that is fuelled by demand for nontraded goods, particularly if production in the traded goods sector is less labor intensive than production in the nontraded goods sector. Thus measures of price pressures based on estimates of the overall output gap are likely to over- or underestimate the true underlying price pressures, depending on the structure of the expansion. 


\section{Data Sources}

Bank of Korea, Monthly Statistical Bulletin, various issues: balance of payments, consumer prices, producer prices, export prices, and import prices; employment, unemployment, and labor force.

Bank of Korea, National Accounts, various issues: GDP in constant 1990 prices, sectoral value added, national disposable income and its appropriation.

IMF, International Financial Statistics, various issues: exchange rates, export unit values.

Ministry of Labor, Yearbook of Labor Statistics, various issues: total monthly compensation by sector, average hours worked per month. 


\section{References}

Adams, C., and D. Coe (1990), "A Systems Approach to Estimating the Natural Rate of Unemployment and Potential Output for the United States," IMF Staff Papers, Vol. 37, pp. 332-93.

Aspe, P., and F. Giavazzi (1982), "The Short Run Behaviour of Prices and Output in the Exportables Sector," Journal of International Economics, Vol. 12, pp. 83-93.

Athukorala, P. (1991), "Exchange Rate Pass-Through: The Case of Korean Exports of Manufactures," Economic Letters, Vol. 35, pp. 79-84.

Aukrust, 0. (1977), "Inflation in the Open Economy: A Norwegian Model," in L. Krause and W. Salant (eds.), Worldwide Inflation, The Brookings Institution.

Blanchard, 0. (1987), "Aggregate and Individual Price Adjustment," Brookings Papers on Economic Activity, Vol. 1:1987, pp. 57-122.

Caves, R. E. (1976), "Looking at Inflation in the Open Economy," in D. Belsley et al. (eds.), Inflation. Trade and Taxes, Ohio State University Press.

De Gregorio, J., A. Giovannini, and H. C. Wolf (1994), "International Evidence on Tradables and Nontradables Inflation," European Economic Review, Vol. 38, pp. 1225-44.

Dornbusch, R. (1974), "Real and Monetary Aspects of the Effects of Exchange Rate Changes," in R. Z. Aliber (ed.), National Monetary Policies and the International Financial System, University of Chicago Press.

Eckstein, 0., and G. Fromm (1968), "The Price Equation," The American Economic Review, Vol. LVIII, 1159-83.

Gordon, R.J. (1994), "Comments on International Evidence on Tradables and Nontradables Inflation," European Economic Review, Vol. 38, pp. 1245-49.

Gulde, A. M. (1989), "Exchange Rates, Imperfect Competition and Export Pricing: The German Case," Doctoral Dissertation, No. 458, Université de Genève.

Kierzkowski, H. (1976), "Theoretical Foundations of the Scandinavian Model of Inflation," The Manchester School, Vol. 44, pp. 232-46.

Kim, Choongsoo (1994), "Wage Policy and Labor Market Development," in S. Haggard et al. (eds.), Macroeconomic Policy and Adjustment in Korea. 1970-1990, Harvard Institute for International Development. 
Korea Employers' Federation (1990), Industrial Relations in Korea, Seoul, Republic of Korea.

Lindbeck, A. (1979), "Imported and Structural Inflation and Aggregate Demand: The Scandinavian Model Reconstructed," in A. Lindbeck (ed.), Inflation and Employment in Open Economies, North-Holland Publishing Company.

Ohno, K. (1989), "Export Pricing Behavior of Manufacturing: A U.S.-Japan Comparison," IMF Staff Papers, Vol. 36, pp. 550-79. 


\section{Trade Policy $1 /$}

Korea's trade policy since the early 1980s has been characterized by a series of comprehensive, albeit gradual, reforms designed to eliminate quantitative restrictions on imports, reduce average tariff rates, and open domestic markets to foreign direct investment. The pace of reforms has been faster in the manufacturing sector than in the agricultural sector, and by end-1994 Korea had removed virtually all nontariff barriers on manufactured imports, reduced the average tariff on nonagricultural imports to the level of industrial trading partners, and opened a significant share of domestic industries--mostly manufacturing--to foreign direct investment. Korea is a member of the World Trade Organization (WTO).

Despite progress in these areas, a number of issues have created frictions in bilateral trade relations. The most important of these issues currently concern Korea's import diversification program designed to reduce large bilateral trade imbalances, the further opening up of the domestic services sector to foreign participation, and the removal of nontariff barriers, particularly for agricultural imports and automobiles.

\section{Reform programs}

Reforms in Korea's trade regime have been carried out in a series of preannounced reform programs in the areas of import liberalization, tariff reduction, and the expansion of the number of industries eligible for foreign direct investment.

Import liberalization programs initially focused on eliminating quantitative restrictions on manufactured imports. As a result, virtually all licensing requirements $2 /$ on manufactured imports were lifted, raising the import liberalization ratio for manufactures to 99.7 percent in 1994. In recent years, the focus has shifted toward liberalizing agricultural imports. The current import liberalization program, covering 1995-97, was submitted to the GATT in April 1994, and reflects the outcome of the Uruguay Round of trade negotiations. Under this program, 142 products (of which 134 are agricultural, forestry and fishery products) of the remaining 150 products under quantitative restrictions are scheduled to be taken off the restricted list by 1997. 3 / As for the remaining 8 products (all agricultural), Korea will increase their import quotas or introduce tariffs in the year 2001. 4/ Completion of the current import liberalization

If Prepared by Dimitri Tzanninis.

2/ Licensing for liberalized imports is automatic.

3/ In 1995, 49 agricultural products were taken off the restricted 1ist, raising the import liberalization ratio for agricultural products to 95 percent.

4/ The Korean Government has adopted a slower pace of liberalization of agricultural trade primarily to protect farm incomes, and facilitate a gradual structural adjustment in the agricultural sector. 
program would fulfill Korea's commitment to eliminate or otherwise bring into conformity with GATT provisions all remaining restrictions on merchandise imports by July 1997.

In addition to phasing out quantitative restrictions, Korea has implemented a tariff reform designed to lower average tariff rates and reduce the dispersion of tariffs. As a result, the average tariff on manufacturing imports was reduced to a level comparable to the rates in industrial countries. The weighted average tariff rate on total imports is currently 7.9 percent (16.6 percent for agricultural imports and 6.2 percent for nonagricultural imports). This compares to a weighted average rate of 18.1 percent for total imports (25.2 percent for agricultural imports and 16.9 percent for nonagricultural imports) in December 1988, when the current program was introduced. The tariff reform has resulted in a marked reduction in the dispersion of tariff rates. At present, the proportion of items with tariffs not exceeding 10 percent is 93.4 percent (compared to 25.8 percent in 1988), with only 6.7 percent of tariffs at 20 percent or higher (compared to 69.9 percent in 1988).

Steady progress has been made in opening up domestic industries to foreign competition. Nevertheless, foreign access to agricultural and services markets remains more restricted than to markets for manufactures where foreign direct investment is almost completely liberalized in all but 10 of 585 industries. The latest five-year plan for the liberalization of foreign direct investment, covering 1993-97, envisages an increase of the liberalization ratio for services (the share of industries eligible for foreign direct investment) from the current 84 percent to 87 percent by 1997. The transport and communications, and finance and insurance industries are presently among the least accessible to foreign participation.

\section{Bilateral issues}

Bilateral issues with Korea's largest trade partners (the European Union, Japan, and the United States) in recent years have been largely related to foreign access to Korean markets rather than Korean exports to these markets. Reflecting that, the number of nontariff barriers on Korean exports has decreased marginally in recent years. 1

Trade frictions with European Union countries have recently centered on pricing policies of certain Korean exports to these countries. While in the past the European Union had imposed antidumping duties on these exports, at

1) The number of restrictions imposed on Korean exports by trading partners remained broadly unchanged in 1994, with anti-dumping duties representing the single most common trade restriction. Exports of products facing restrictions to OECD countries have decline in recent years, reflecting an effort by Korean exporters to diversify out of such products and countries. 
present, these issues are being addressed through bilateral negotiations, which are scheduled to be concluded by the end of 1995 .

A source of frictions in bilateral relations remains Korea's import diversification program. This program was designed to correct large and persistent bilateral trade imbalances by encouraging importers to shift imports of designated items away from countries with which Korea maintains large trade deficits. The Korean Government has announced its plan to reduce significantly by 1998 the number of items currently included in the program--mostly heavy machinery and consumer electronics. To this end, it removed 47 items from the list in 1995, which now includes 183 items.

Three major issues in bilateral trade relations with the U.S. stand out at present, all pertaining to access to Korean markets: the testing, inspection, and shelf life of imported agricultural products; the opening of financial markets to foreign companies; and foreign access to Korea's automobile market. As regards the first two issues, consultations are under way in accordance with WTO rules on the settlement of disputes. The U.S. has asked the Korean Government to change its testing and inspection system for imported agricultural products in order to expedite customs clearance, and permit producers to determine the shelf life of their products. It has also asked for an acceleration of the pace of opening the financial sector to foreign competition.

Some progress was made in 1994-95 in improving foreign access to Korea's automobile market. The Korean Government took a number of measures in response to U.S. requests for tariff reductions, changes in the internal tax system, and elimination of restrictions in distribution and advertizing. A plan was introduced in June 1994 to open the domestic automobile market, mainly through a reduction in the tariff rate on automobile imports from 10 percent to 8 percent. Following negotiations with the U.S. Trade Representative, the U.S. and Korean Governments reached an agreement in September 1995 to further improve access in the Korean automobile market. The agreement envisages a reduction in the registration tax applied to luxury automobiles (which are mainly imported), the easing of certain standards and certification procedures, access for foreign financing firms to the Korean autonobile financing business, and access for foreign automobile manufacturers to television advertizing. Progress on the implementation of the agreement would be monitored closely and the agreement would be reconsidered in June 1996. 